\author{
Universidade de São Paulo \\ Faculdade de Filosofia, Letras e Ciências Humanas
}

\begin{abstract}
Departamento de Letras Modernas
Programa de Pós-Graduação em Língua Espanhola e Literaturas Espanhola e Hispano-Americana
\end{abstract}

Debora Duarte dos Santos

\title{
Cartografias corporais em trânsito: violência, desejo e êxtase na escrita de Néstor Perlongher
}


Debora Duarte dos Santos

\title{
Cartografias corporais em trânsito: violência, desejo e êxtase na escrita de Néstor Perlongher
}

\author{
Tese apresentada ao Programa de Pós-Graduação em \\ Língua Espanhola e Literaturas Espanhola e Hispano- \\ Americana, do Departamento de Letras Modernas, da \\ Universidade de São Paulo, como requisito para a obtenção \\ do título de Doutora em Letras.
}

Orientador: Pablo Fernando Gasparini 
Debora Duarte dos Santos

\section{Cartografias corporais em trânsito: violência, desejo e êxtase na escrita de Néstor Perlongher}

Tese apresentada ao Programa de Pós-Graduação em Língua Espanhola e Literaturas Espanhola e Hispano-Americana da Universidade de São Paulo.

Área de Concentração: Literatura Hispano-Americana

Aprovada em:

\section{Banca Examinadora}

Prof. Dr. Pablo Fernando Gasparini (Orientador)

Universidade de São Paulo (USP)

Prof $^{a}$. Dr ${ }^{\mathrm{a}}$. Adriana Kanzepolsky

Universidade de São Paulo (USP)

Prof $^{\mathrm{a}}$. Dra ${ }^{\mathrm{a}}$. Silvia Beatriz Adoue

Universidade Estadual "Júlio de Mesquita Filho" (UNESP)

Prof. Dr. Jorge Bracamonte

Universidad Nacional de Córdoba (UNC, Argentina) 
Aos meus pais, Maria Betânia e Cicero.

Ao meu orientador, Pablo Fernando Gasparini. 


\section{AGRADECIMENTOS}

A palavra convoca nossa dignidade: o direito a nomear, a escavar sentidos, a enxergar o mundo simbolicamente constituído; ou como assinalava Antonio Candido: a palavra nos entrega a possibilidade de viver dialeticamente os problemas. $\mathrm{O}$ exílio em relação à palavra representa não só um hiato na existência, como uma das piores formas de violentar a dignidade humana. Cresci no terreno das vidas secas, do chão árido, lavrado pelo silêncio ao invés da palavra. A vida acadêmica, contudo, me deu de beber desta "água viva": e tudo isso é como uma alegria profunda e inominável. Como diria Clarice Lispector: "É um tal aleluia. Aleluia, grito eu, aleluia que se funde com o mais escuro uivo humano de dor de separação mas é grito de felicidade diabólica"1.

Por outra parte, vale dizer que este grito de felicidade não é tão solitário quanto parece, afinal não são só os personagens de ficção que nos acompanham: a viagem é real, principalmente porque pressupõe a participação e o apoio de uma tripulação que, muito embora opte por um protagonismo difuso e pouco exuberante, são personagens que ocupam um lugar maior nos enredos desta trama. Aos companheiros de travessia, portanto, meus mais sinceros agradecimentos.

Agradeço a Deus, aos meus pais, à minha família e de modo especial à minha prima, Fatima Araujo Duarte.

Aos professores do Programa de Língua Espanhola e Literaturas Espanhola e HispanoAmericana, da Universidade de São Paulo: Ana Cecilia Árias Olmos, Idalia Morejón Arnaiz, Laura Janina Hosiasson e, especialmente, ao meu orientador professor Pablo Fernando Gasparini e à professora Adriana Kanzepolsky não somente pelas leituras e

\footnotetext{
${ }^{1}$ LISPECTOR, Clarice. Água viva. Rio de Janeiro: Rocco, 1998, p. 9.
} 
diálogos travados ao longo dos últimos sete anos, mas sobretudo porque sempre estiveram atentos, dispostos e de coração aberto.

À professora Silvia Beatriz Adoue, cuja motivação, ainda no mestrado, me levou a conhecer Chicha Mariani, e consequentemente me aproximar da história argentina.

Ao professor Jorge Bracamonte pelas leituras e contribuições desde o exame de qualificação.

A Javier Gasparri - quem também me ensinou a encontrar Néstor Perlongher no fim de tarde paulistano -, por suas contribuições e amizade.

À família Robalo e Adroilson Vieira de Campos, que me acolheram durante a curta estadia em Aracaju.

Aos amigos Clarisse Lyra Simões, Ellen Maria Martins de Vasconcellos, Letícia Marteis, Noemi Carrera, Elielson Antônio Sgarbi, Hugo César Ledo e Luiz César Dias e Silva.

Aos colegas do Programa de Pós-Graduação em Língua Espanhola e Literaturas Espanhola e Hispano-Americana.

Aos colegas do Instituto Federal de Educação, Ciência e Tecnologia de São Paulo (IFSP), campus Suzano: Diego Salim, Kely Souza, Marcela Loureiro, Rafael Pereira e Raquel Lima Silva.

Aos funcionários do Departamento de Letras Modernas, da Secretaria de Pós-Graduação e da Biblioteca "Florestan Fernandes" da Faculdade de Filosofia, Letras e Ciências Humanas.

À Universidade de São Paulo e à Coordenação de Aperfeiçoamento de Pessoal de Nível Superior (CAPES) pelo financiamento desta pesquisa. 
"Seria paradoxal que o medo da morte nos fizesse perder o gosto da vida".

(Néstor Perlongher, 1987b, p. 92). 
"Que cada cual pueda encontrar, más allá de las clasificaciones, el punto de su goce".

(Néstor Perlongher, 1997a, p. 33). 


\section{RESUMO}

SANTOS, Debora Duarte dos. Cartografias corporais em trânsito: violência, desejo e êxtase na escrita de Néstor Perlongher. 2019. 181 f. Tese (Doutorado) - Faculdade de Filosofia, Letras e Ciências Humanas da Universidade de São Paulo, São Paulo, 2019.

A presente tese tem por objetivo analisar - pelo viés do corpo e da corporalidade - a miscelânea de textos produzidos por Néstor Osvaldo Perlongher (Avellaneda, 1949 - São Paulo, 1992) entre os anos de 1980 e 1992, tais como: pesquisas, ensaios, artigos, entrevistas, contos, crônicas e poemas, com especial atenção à edição preparada por Christian Ferrer e Osvaldo Baigorria, Prosa plebeya: Ensayos; e Poemas completos, que conta com seleção e prólogo de Roberto Echavarren. Com efeito, é de nosso interesse verificar como o corpo aparece inscrito no corpus selecionado, propondo com isto que a escrita perlongheriana perfura as fronteiras que intentam delimitar suas qualidades semânticas por meio de enquadramentos e formas hegemônicas da crítica. Dito isto, revela-se não só a consubstancialidade desta escrita como também as diferentes estratégias de experimentação e performance que opera. As análises têm como ponto de partida o corpo como metáfora sensorial por excelência, como importante eixo discursivo e reservatório do social, sobretudo porque é explorado como via de transgressão atravessada pelo desejo e a partir da qual se instaura uma linguagem sui generis. Para tanto, revisitamos não só importantes discussões e variáveis apresentadas pela crítica especializada, como também nos dedicamos aos conceitos desenvolvidos por críticos como Michel Foucault (1984, 1988), Judith Butler (2003), Gilles Deleuze e Félix Guattari (1980, 1992, 2000, 2011, 2012), Jean-Luc Nancy (2014), entre outros. Por fim, após este percurso e com a perspectiva teórica e o corpus mencionados, apresentamos algumas considerações no que se refere à hipótese inicial de nossa tese, a de que, para além da leitura hegemônica de que sempre se valeu a crítica literária, a escrita perlongheriana passa a ser compreendida - de forma contundente - como "testemunha e protagonista exemplar de seu tempo" (ECHAVARREN, 2001, p. 109).

Palavras-chave: Néstor Perlongher, Poemas completos, Prosa plebeya, corpo, produção de sentido. 


\begin{abstract}
SANTOS, Debora Duarte dos. Bodily cartographies in transit: violence, desire and ecstasy in Néstor Perlongher's writing. 2019. $181 \mathrm{f}$. Tese (Doutorado) - Faculdade de Filosofia, Letras e Ciências Humanas da Universidade de São Paulo, São Paulo, 2019.
\end{abstract}

This thesis aims to analyze - through the body and corporality - a variety of texts written by Nestor Osvaldo Perlongher (Avellaneda, 1949 - São Paulo, 1992) between 1980 and 1992, such as research, essays, articles, interviews, short stories, chronicles and poems, paying special attention given to an edition prepared by Christian Ferrer and Osvaldo Baigorria, Prosa plebeya: Ensayos; e Poemas completos, whose selection and prologue were organized by Roberto Echavarren. Thus, this thesis intends to verify how the body appears in the corpus selected, suggesting that the perlongheriana writing extends the boundaries which intends to delimit its semantic qualities through hegemonic framework and forms of criticism. In this sense, not only the consubstantiality of this form of writing is revealed but also the different strategies of experimentation and performance in which they are operated. The starting point for the analysis is the body as a sensorial metaphor par excellence, as an important discursive axis and social reservoir, mainly because it is explored as a means of transgression surpassed by the desire, from which a sui generis language is established. Therefore, not only did we revisit important discussions and variables presented by the critics, but also dedicated to concepts developed by critics such as Michel Foucault (1984, 1988), Judith Butler (2003), Gilles Deleuze e Félix Guattari (1980, 1992, 2000, 2011, 2012), Jean-Luc Nancy (2014), among others. Finally, after such reflections and with the theoretical perspective and the corpus mentioned, we presented some considerations which refer to the initial hypothesis of this thesis, that is, beyond hegemonic reading that have always been used by literary criticism, the perlongheriana writing begins to be understood - in a crucial way - as "testimony and protagonist of its time" (ECHAVARREN, 2001, p. 109).

Key-words: Néstor Perlongher, Complete Poems, Prosa plebeya, body, sense production. 


\section{RESUMEN}

SANTOS, Debora Duarte dos. Cartografías corporales en tránsito: violencia, deseo y éxtasis en la escritura de Néstor Perlongher. 2019. 181 f. Tese (Doutorado) Faculdade de Filosofia, Letras e Ciências Humanas da Universidade de São Paulo, São Paulo, 2019.

La presente tesis tiene por objetivo analizar - por la vía del cuerpo y de la corporalidad la miscelánea de textos producidos por Néstor Osvaldo Perlongher (Avellaneda, 1949 São Paulo, 1992) entre los años de 1980 y 1992, tales como: investigaciones, ensayos, artículos, entrevistas, cuentos, crónicas y poemas, dando especial énfasis a la edición preparada por Christian Ferrer y Osvaldo Baigorria, Prosa plebeya: Ensayos; y Poemas completos, que cuenta con selección y prólogo de Roberto Echavarren. Con efecto, es de nuestro interés verificar como el cuerpo aparece inscripto en el corpus seleccionado, sugiriendo con esto que la escritura perlongheriana atraviesa las fronteras que intentan fijar límites a sus cualidades semánticas, por medio de encuadramientos y formas hegemónicas de la crítica. Dicho esto, se revela no sólo la consubstancialidad sino también las distintas estrategias de experimentación y performance que opera. Los análisis tienen como punto de arranque el cuerpo como metáfora sensorial por excelencia, como importante eje discursivo y reservatorio de lo social, sobre todo porque es explotado como vía de transgresión cruzada por el deseo y desde la cual se instaura un lenguaje sui generis. Para tanto, retomamos no sólo importantes discusiones y variables presentadas por la crítica especializada, como también damos especial atención a los conceptos desarrollados por críticos como Michel Foucault (1984, 1988), Judith Butler (2003), Gilles Deleuze y Félix Guattari (1980, 1992, 2000, 2011, 2012), Jean-Luc Nancy (2014), entre otros. Finalmente, luego de este trayecto y de la perspectiva teórica y el corpus mencionados, presentamos algunas consideraciones respeto a la hipótesis inicial de nuestra tesis, la de que, más allá de la lectura hegemónica de que siempre se ha utilizado la crítica literaria, la escritura perlongheriana empieza a ser comprendida - de forma contundente - como "testigo y protagonista ejemplar de su tiempo" (ECHAVARREN, 2001, p. 109).

Palabras clave: Néstor Perlongher, Poemas completos, Prosa plebeya, cuerpo, producción de sentido. 


\section{RÉSUMÉ}

SANTOS, Debora Duarte dos. Cartographies corporelles en transit: violence, désir et extase dans l'écriture de Néstor Perlongher. 2019. $181 \mathrm{f}$. Tese (Doutorado) Faculdade de Filosofia, Letras e Ciências Humanas da Universidade de São Paulo, São Paulo, 2019.

Cette thèse a pour but d'analyser - par le biais du corps et de la corporalité - l'ensemble de différents types de textes produits par Néstor Osvaldo Perlongher (Avellaneda, 1949 - São Paulo, 1992) entre 1980 et 1992, tels que recherches, articles, interviews, nouvelles, chroniques et poèmes, mais de manière particulièrement intéressée à l'édition préparée par Christian Ferrer et Osvaldo Baigorria, Prosa plebeya: Ensaios et Poemas completos, dont la sélection et le prologue se doivent à Roberto Echavarren. L'intérêt de la recherche a été de vérifier comment le corps se fait présent dans le corpus sélectionné et en conséquence, de proposer que l'écriture perlonghérienne perce les frontières qui tentent de délimiter ses qualités sémantiques ayant pour base des modèles et des formes hégémoniques de la critique. Cela dit, non seulement la consubstantialité de cette écriture se révèle, mais aussi les différentes stratégies d'expérimentation et de performance qu'elle opère. Les analyses ont le corps pour point de départ comme métaphore sensorielle par excellence, un axe discursif important et réservoir du social, surtout parce qu'il est exploré comme une voie de transgression traversé par le désir et à partir duquel un langage sui generis s'établit. Pour cela, nous avons recouru non seulement à des aspects et discussions importantes présentées par la critique spécialisée, mais aussi aux concepts développés par des critiques tels que Michel Foucault (1984, 1988), Judith Butler (2003), Gilles Deleuze et Félix Guattari (1980, 1992, 2000, 2011, 2012), Jean-Luc Nancy (2014), entre autres. Finalement, après ce parcours, avec la perspective théorique et le corpus mentionnés, nous présentons quelques considérations en ce qui concerne l'hypothèse initiale de notre thèse selon laquelle, au-delà de lecture hégémonique desquels la critique littéraire s'est toujours utilisée, l'écriture perlonghérienne est desormais comprise - de façon aiguë comme "témoin et protagoniste exemplaire de son temps" (ECHAVARREN, 2001, p.109).

Mots-clés: Néstor Perlongher, Poemas completos, Prosa plebeya, corps, production de sens. 


\section{ÍNDICE}

CAPÍTULO I - Instabilidades topográficas, genéricas e formais...............................28

1.1. Prolegômenos a uma cartografia nômade......................................28

1.1.1. A instabilidade como estratégia de escrita................................29

1.2. Instabilidade e produção de sentido ........................................... 38

1.3. O “grão da voz”: escucha imaginaria e produção de sentido........................41

1.4. É possível escrever poesia após a barbárie? A matéria poética como mediação entre o homem e o mundo...........................................................47

CAPÍTULO $\Pi$ - Corporalidades em ruínas: os “cadáveres” da nação..........................58

2.1. Perlongher, o aedo de thánatos; ou a morte como ordem fundadora...........................58

2.2. A antinaturalidade do cadáver de Eva Perón............................................................66

2.3. O cadáver da nação: entre o sagrado e o êxtase............................................................72

CAPÍTULO III - “Nas barras da lei”: corporalidades clausuradas e a ameaça ao

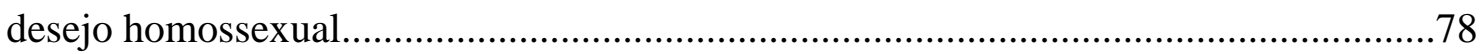

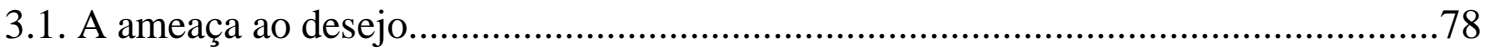

3.2. A prisão de Antônio Chrysóstomo: O julgamento de um preconceito.........................82

3.3. O curto-circuito das relações: biopolítica e insubmissão.........................................89

3.4. Um longo ensaio sobre o desejo: $O$ negócio do michê..............................................96

3.4.1. O confinamento do desejo: "operação limpeza" .........................................102

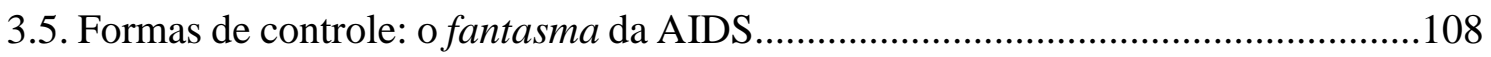

CAPÍTULO IV - Do trottoir ao boudoir do poeta; ou cartografias corporais em transe,

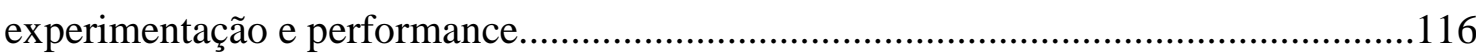

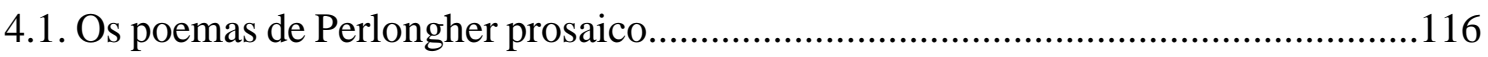

4.2. Hule: erotismo, desejo e o trottoir do poeta...........................................................119 
4.4. El chorreo de las iluminaciones: da contemplação selvática às formas de ingresso interior.

CONSIDERACÕES FINAIS 


\section{INTRODUÇÃO}

O texto literário enquanto "[...] realidade perdurável e sensível” como assinalado por Domingos Carvalho da Silva (1989, p. 21) é tanto objeto inefável como herdeiro de geometrias inquietantes, isto é, de desvios linguísticos e insubmissões formais operados pelo escritor. Em $O$ arco e a lira (1956), Octavio Paz assinalava estas questões evidenciando a particularidade do objeto poético, cuja técnica sucumbe ao exato momento da criação. Aspectos como estes permitem-nos compreender que os movimentos de escrita transitam entre a possibilidade da técnica, os delírios e a suspensão. Podemos estender estas declarações ao campo da leitura de textos literários, considerando que - muito embora falemos em favor da inter-, intra- e, mais atualmente, da hipertextualidade, isto é, de textos que com frequência se expandem e retomam uns aos outros -, os processos de leitura e exegese conservam uma índole expressivamente singular, já que evidenciam a função disruptiva da língua ao mesmo tempo que procuram compreender os espaços em branco deixados pelo escritor. Ainda assim os valores nunca serão absolutos: na roda-viva da língua: tudo nasce e morre no exato momento da criação...

Com este trabalho não foi diferente, ainda que seu embrião tenha surgido em princípios de 2014, quando concluíamos nossa dissertação de mestrado "Un mundo más allá del mío": violência e inocência em La casa de los conejos, de Laura Alcoba". Esta tese de doutoramento soma-se e distancia-se daquela por uma série de questões: naquela, interessávamos pelos diálogos entre a literatura, o discurso histórico e a memória; nesta, entretanto, enfatizamos a inabalável lepra [letra?] creadora, isto é, o enunciado neobarroco, nas aproximações estabelecidas com a filosofia, a história e a antropologia. 
Com efeito, trabalharemos com o corpus poético e ensaístico do argentino Néstor Perlongher, exilado no Brasil no início dos anos 80, transitando, ainda, pela miríade de textos e temas produzidos entre 1980 e 1992, que não só representam a importante contribuição de Néstor Perlongher para o cenário da crítica e da literatura, como também ratificam a influência do escritor às mais distintas áreas de estudos.

Ao longo de um pouco mais de uma década Néstor Perlongher escreveu antologias, ensaios e contribuiu com uma série de jornais e revistas. Sua produção, além de densa e disruptiva, reúne uns tantos números, entre os quais: Austria-Hungría (Buenos Aires, Tierra Baldía, 1980); Alambres (Buenos Aires, Último Reino, 1987; Prêmio "Boris Vian" de Literatura Argentina); Hule (Buenos Aires, Último Reino, 1989); Parque Lezama (Buenos Aires, Sudamericana, 1990); Aguas aéreas (Buenos Aires, Último Reino, 1991) e El chorreo de las iluminaciones (Caracas, Pequeña Venecia, 1992). Como ensaísta atuou principalmente nas revistas El Porteño, Alfonsina, Último Reino e Diario de Poesía ${ }^{2}$. Junto ao Departamento de Antropologia Social da Universidade Estadual de Campinas (UNICAMP), Néstor Perlongher apresentou a dissertação de mestrado $O$ negócio do michê: prostituição viril em São Paulo (1986) -, um dos trabalhos mais emblemáticos já produzidos sobre o tema, que acabou sendo publicado em 1987 pela editora Iluminuras. Também é de sua autoria El fantasma del SIDA publicado pelo selo editorial Puntosur no ano de 1988, e a organização de Caribe Transplatino: Poesia

\footnotetext{
${ }^{2}$ Como Adrián Cangi aponta em nota de rodapé: "Perlongher colaboró con cierta regularidad en varias revistas culturales y periódicos de la década del ochenta hasta 1992 [...]". Na Argentina, ademais dos citados, "[...] publicó artículos en Babel, [...], Cerdos y peces, Utopía, Fin de siglo, Cuadernos de la comuna, Persona, Farenheit 450 [...]. En São Paulo, publicó su primer artículo en portugués en $O$ inimigo do rei en 1982; a partir de 1985, colaboró en reiteradas oportunidades para las secciones "Tendencias y debates", "Cidades" y "Folhetim" de la Folha de São Paulo; también colaboró con el Diario do Povo; en Comunicações do ISER, en Temas IMESC y, posteriormente, en Saúdelocura. Dentro de Brasil también publica en Nicolau, de Curitiba. Durante estos años publicó en Nueva Sociedad, de Caracas; en la Revista de crítica cultural de Santiago de Chile, en el semanario Jaque de Montevideo, en Hispamérica en EEUU, en ECO de Bogotá y en Chimères de Paris" (2000a, p. 78).
} 
neobarroca, cubana e rioplatense (São Paulo, Iluminuras, 1991). Perlongher morreu vítima de AIDs em São Paulo, em novembro de 1992 e, de acordo com José Quiroga ${ }^{3}$,

Fue una de las voces más abiertas cuando la realidad pacata quería esconder los verdaderos estragos de la enfermedad. Y entre sus legados, toda irrealidad gozosa, enjoyada, maquillada, que se concentra en esa imagen que responde Perlongher a la imagen de la madre lezamiana: la diosa puta que también es un pastiche, un travesti, un punto de arranque efectivo para una lucha política que sea toda superficie pulsante de inconcebibles identidades: Evita Perón con aires de lupanar, diosa masturbatoria.

No desenvolvimento desta pesquisa observamos as posições assumidas por Néstor Perlongher, principalmente quando interpreta a falência da lógica tradicional de alguns setores da sociedade do final do século XX. Neste sentido, determinados aspectos chamam nossa atenção como, por exemplo, o cenário sobre o qual se produz o debate perlongheriano, cujo pano de fundo revela que Néstor Perlongher “[...] arrojó textos e ideas a la hoguera de consciencias púdicas y escandalizadas [...]"4, sobretudo numa época em que regimes de produção de subjetivação normatizavam a vida. Néstor Perlongher atentou contra os regimes disciplinares, provocando o que os franceses Gilles Deleuze e Félix Guattari (2012) chamaram de "revolução molecular": a revolução - diria Perlongher- "[...] es un acto de amor" (1997a, p. 247). O poeta interpretou arquiteturas políticas e regimes disciplinares de produção do sujeito, propondo novas cartografias e rupturas com subjetividades estanques e sedentárias. "Reclamamos simplemente que se reconozca el derecho de cada individuo a disponer de su propio cuerpo y de su propia vida" (Idem).

\footnotetext{
${ }^{3}$ QUIROGA, José. "Homenaje a Néstor Perlongher - El chorro de Perlongher". Texto disponível em: http://www.habanaelegante.com/Spring2001/Expresion.html. Acesso em novembro de 2015. ${ }^{4}$ Excerto extraído do vídeo disponível em: http://www.bn.gov.ar/video/alambres-de-nestor-perlongher-el-
libro-perdido. Acesso em 12 de setembro de 2015.
} 
Menos que suplicar o mandato dos sentidos - até porque herdeiro da tradição neobarroca -, Néstor Perlongher foi um escritor que nos convidou ao ritmo, ao jogo dos significantes, à cadência e ao escândalo da língua: “[...] su poesía hace de la lengua torsión inédita y del español una superficie alterada por el portugués" (Idem), e se como dizia José Lezama Lima: “[...] cómo la verdadera naturaleza se ha perdido, hay que inventar una sobrenaturaleza [...]", o poeta argentino a inventa: Néstor Perlongher invade o neobarroco cubano ${ }^{5}$, lo festonea, e o faz proliferar na estética neobarrosa. Em Caribe Transplatino: poesia neobarroca, cubana e rioplatense (1991), Perlongher escreve:

Invasão de dobras, orlas iridescentes ou drapeados magníficos, o neobarroco prolifera nas letras latino-americanas; a "lepra creadora" lezamesca mina ou corrói - minoritária mas eficazmente - os estilos oficiais do bem dizer [...]. Passeio esquizo do senhor barroco, nomadismo na fixidez. São as viagens mais esplêndidas: "as que um homem pode tentar pelos corredores de sua casa, indo do quarto para o banheiro, desfilando entre parques e livrarias". (pp. 13-15).

Ao enfatizar a presença do neobarroco em território sul-americano, Néstor Perlongher apresentou textualidades imersas em constantes oscilações e turbulências, colocando em evidência a "operação de montagem sobre um estilo anterior": ou seja, a estética neobarrosa. No prólogo a Caribe transplatino: poesia neobarroca cubana e rioplatense (1991), Néstor Perlongher sinaliza que a "experiência radical" desta estética

\footnotetext{
${ }^{5}$ Em "Perlongher prosaico", prólogo à Prosa plebeya: Ensayos, Christian Ferrer e Osvaldo Biagorria escrevem: "[...] gran tema de Néstor es el neobarroco, corriente literaria en la cual se sentía a gusto, de la cual fue uno de sus principales animadores y cuyos contornos cinceló preciosística y minuciosamente, tal como se puede apreciar en los ensayos [...]. Perlongher siempre rechazó el uso comunicacional del lenguaje; más bien prefería deslizarse por sus sonoridades y contorsiones, como un kayak llevado por la corriente. La sonoridad sensual del texto, la exuberancia del léxico, el indisociable esponsal entre el argumento y el derrame poético, nos sugieren la posibilidad de entender a buena parte de sus escritos como un teatro de operaciones lingüísticas en estado de trance" (1997, p.12, grifos nossos).
} 
pode ser verificada a partir dos textos de Osvaldo Lamborghini, "a quem não se vacilaria em outorgar os louros da invenção" .

Em "El escudo de la muerte" (1988), sem eludir os aspectos constitutivos da escrita de Osvaldo Lamborghini, Tamara Kamenszain revela uma espécie de "paternidade" deste com relação a Néstor Perlongher e outros poetas argentinos. É interessante notar que a autora não chega aos poetas sem antes propor uma interessante analogia com a herança deixada pelo autor de El Aleph. Para Kamenszain: "Si padre literario es aquél cuya huella se vuelve ineludible - como Borges para los narradores -, los poetas argentinos nacimos huérfanos" (1988, p. 115). Se por um lado o lugar do pai aparece como um espaço vazio, símbolo da orfandade; por outro Tamara Kamenszain aponta que "[...] desde que Osvaldo Lamborghini se sentó a escribir, ya impuso una paternidad [...] - ainda que caminhar no terreno da "filiação" seja algo "muy de padres y hijos", uma visão não só edípica como também atravessada por "crisis de paternidad"”, como discute Néstor Perlongher. Para autora, "Si antes armamos un golem para convertirlo en padrino literario, hoy, podemos decir que Lamborghini emerge de nuestro laboratorio como aquel tatita joven que nos tiene dominados (domeñados escribiría él)" (Idem, pp. 115-116). Após, ressalta:

\footnotetext{
${ }^{6}$ Elsa Drucaroff em "Los hijos de Osvaldo Lamborghini" (1997, pp. 145-154) diz sobre Osvaldo Lamborghini: a) "[...] Lamborghini comparte, aunque no desde una fantasía referencial [...] que su literatura realiza una apuesta trascendente y se inscribe, como toda vanguardia, en la utopía de revolucionar el Orden de la escritura"; b) (STEIMBERG apud DRUCAROFF, Elsa, 1997, p. 154): "Ya cuando era un personaje, en 1983, fue a una fiesta de escritores y bailó toda la noche con Néstor Perlongher"; c) "Estamos frente a textos que esgrimen un ator que insiste en afirmar la autobiografía y experimentar con su identidad a partir de posiciones de riesgo diversas (riesgo en su definición sexual, riesgo en su pensamiento y acción políticas, riesgo respecto de la razón y el Logos, riesgo al trabajar con las posibilidades extremas de la percepción sensorial, riesgo respecto de los cánones estéticos).

7 "Neobarroso y el realismo alucinante", entrevista que Néstor Perlongher concedeu a Pablo Dreizik, publicada em Tiempo Argentino, em agosto de 1986.
} 
Sobre este terreno arduamente alisado por [...] Lamborghini, puede ahora retozar con toda tranquilidad la poesía joven de Néstor Perlongher [...]. Seguro, alimentado por un padre, avalado por una tradición, Perlongher correteará saludable hasta merodear cerca de un verdadero tabú argentino: el barroco [...]. Con empuje dominguero - no muy usual para nuestra poesía de días laborales -, Perlongher extrajo del domingo porteño una especie de trópico. Los «saquitos de banlon», las «ligas», las «carteras con francés», los «breteles ácidos», las «bombachas de naylon», no cuelgan del cuerpo metafórico de las chicas de Flores, sino que se descuelgan sobre la página para construir, dentro de ella, el emporio de los materiales [...]. Junto con el amontonamiento de materiales irrumpen sus infinitas combinatorias para el verso. (KAMENSZAIN, 1988, p. 118).

Em sentido amplo, o projeto de escrita apresentado por Néstor Perlongher renuncia as categorias lineares e denotativas do enunciado formal. Para o escritor era de suma relevância que o trabalho com a língua excedesse os limites taxonômicos, sobretudo porque defendia: “[...] que cada cual pueda encontrar, más allá de las clasificaciones, el punto de su goce" (1997a, p. 33).

Em nossas análises damos especial atenção à ortografia enigmática assumida por Néstor Perlongher no desenvolvimento de seus textos em verso, em prosa e, inclusive, em seus ensaios, que, se por um lado, arquivam o murmúrio neobarroco ou a dissolução por meio das tantas ressemantizações, descentramentos e "combustão fônica", como assinalado por Nicolás Rosa; por outro, permitem ${ }^{8}$ o trabalho com distintas abordagens na condução dos processos de interpretação. Neste sentido, é de nosso interesse evidenciar o lugar que o corpo assume nesta escrita, sublinhando especialmente os momentos em que as metaforizações propõem uma apreensão do social e de toda a conflitividade que conforma sua época. Se por um lado os antecedentes da crítica revelam

\footnotetext{
${ }^{8}$ No desenvolvimento de nossa tese as análises apresentadas propõem questionamentos no que concerne à produção poética de Néstor Perlongher em congruência com a leitura de seus ensaios, cujas interseções, além de explícitas, revelam sobremaneira o porquê de insistir na prosa de um poeta. Por um lado, os ensaios perlongherianos revelam a força de sua poética, argumentam e justificam seus versos e, por outro, surgem como apostas de leitura e interpretação de arquiteturas sociais, históricas e culturais.
} 
acentuada preocupação no que diz respeito ao corpo enquanto arquitetura de rios fluidos, fluxos e escatologias; por outro, retomamos o debate buscando confirmar que, mais uma vez, o verso perlongheriano excede os limites dos discursos que intentam emoldurar as qualidades de sua semântica.

Em nosso trabalho o corpo aparece como território transgressor atravessado pelo desejo, bem como retentor de questões sociais mais amplas, isto é, como reservatório de uma linguagem sui generis. Linguagem que surge perfilada nos delírios de um frenesí em que o collant de banlon, a sutileza de um rodete, los pelos sueltos, bem como as unhas pintadas de verde, operam como argumentos, que revelam marcadores demonstradores de tensões que perpassam o cenário social: o corpo, portanto, passa a ser compreendido como espaço de revolução. Neste sentido, em termos estruturais, esta tese subdivide-se em quatro capítulos, além desta introdução e das considerações finais, a saber:

No primeiro capítulo apresentamos uma espécie de mapeamento cartográfico dos aspectos constitutivos da escrita perlongheriana. Além do caráter introdutório, o capítulo explora a multiplicidade de temas e espaços sobre os quais discorre o poeta e ensaísta, de modo que se torna fundamental explicitar os fluxos e deslizamentos que comprovam uma série de instabilidades no projeto de escrita conduzido por Néstor Perlongher: topográficas, genéricas e formais. Ao longo deste capítulo é possível identificar o trabalho com conceitos dos franceses Gilles Deleuze e Félix Guattari, sobretudo a partir de Mil platôs $(1995,2011,2012)$, quando os filósofos tratam de linhas de segmentaridades duras, de linhas moleculares e de fuga. Observa-se de que modo Néstor Perlongher propõe debates expressamente opostos à lógica hegemônica. $\mathrm{Na}$ ocasião, discutimos considerações apresentadas por Antonio Candido (1996) acerca do enunciado poético, 
bem como trabalhamos com o conceito de "escucha imaginaria" explorado por Ana Porrúa (2011), ocasião em que a autora sublinha o fato de que em algumas poéticas tornase possível "escuchar de modo nuevo", encontrando com isto o "grão da voz" do qual fala Roland Barthes em O óbvio e o obtuso (1990). Finalmente, depois deste trajeto - que de certo modo argumenta em favor da última parte do capítulo -, propomos o seguinte questionamento: afinal, é possível escrever poesia após a barbárie? Ao ser respondida positivamente, a indagação não só justifica a eleição do tema desta tese, como também confirma o fato de que é imprescindível a reatualização da história, sendo que a literatura cumpre um importante papel estético e reflexivo neste processo.

No segundo capítulo a discussão abrange o conceito de estado de exceção de Giorgio Agamben, com base na perspectiva apresentada por Christine Greiner (2005, 2007, 2010), importante pesquisadora das Artes do Corpo ${ }^{9}$. Recuperando o conceito desenvolvido pelo filósofo italiano em Estado de exceção (2004), a autora problematiza as barreiras disciplinares e os regimes exasperantes que passaram a conformar a vida, sobretudo após a Segunda Guerra Mundial. O morto aparece como o abjeto por excelência, como imagem que fere e afeta no sentido profundo do termo. As análises têm como ponto de partida a saga - cadavérica - perlongheriana, considerando poemas como “Cadáveres", "El cadáver", "El cadáver de la nación" e o conto "Evita vive”, em cujas leituras se busca identificar as zonas de indeterminação, bem como de "fabricação de cadáveres”. De acordo com Ezequiel Zaidenwerg: “[...] hay en Perlongher una obsesión

\footnotetext{
${ }^{9}$ Artes do Corpo compreende um campo de estudos relacionado tanto às Artes, quanto - como no caso da autora - à História e aos eventos de ordem política e social. De modo específico, o enquadramento diz respeito ao "Curso de Comunicação das Artes do Corpo" (PUC) que, além de ter como docente a professora Christine Greiner, representa o ponto de partida de uma série de discussões apresentadas em livros produzidos/ organizados, dentre os quais: O corpo: pistas para estudos indisciplinares (2005); Leituras da morte (2007) e $O$ corpo em crise: novas pistas e curto-circuito das representações (2010).
} 
por los cadáveres [...] en el sentido que lo vivo y lo muerto entran en una zona de contigüidad [...]" (2015, p. 443). Nesse sentido, ao analisar estes textos confirmamos o fato de que, com seus "cadáveres", o poeta surge como o aedo de thánatos; a morte, como ordem fundadora.

Nos capítulos III e IV, entretanto, observamos uma espécie de confluência, sobretudo do ponto de vista da forma. Neste sentido, é considerada a extensa cartografia de gêneros - textuais - percorridos por Néstor Perlongher, como: contos, relatos, artigos, ensaios, crônicas, poemas e até a pesquisa de mestrado em Antropologia Social. Para tanto, no teceiro capítulo desta tese damos especial atenção aos aspectos vinculados à prosa, aos ensaios e à dissertação do escritor, analisando os textos e paratextos, que constituem tanto O negócio do michê: prostituição viril (1987a), O que é AIDS (1987b) e Evita vive e outras prosas (2001) quanto Prosa plebeya: ensayos (1980-1992); posteriormente, isto é, no capítulo seguinte, enfatizamos os elementos inerentes à poética, por meio das antologias Hule (1989), Aguas aéreas (1991) e El chorreo de las iluminaciones (1992).

Ressaltando o que durante algum tempo foi considerado pela crítica como um capítulo "menor" da produção escrita perlongheriana, no Capítulo III apresentamos um recorte de aspectos extraídos dos textos em prosa, que em sua grande maioria foram praticamente esquecidos em decorrência da leitura hegemônica dos poemas. Tanto em $O$ negócio do michê: a prostituição viril (1987a) e O que é AIDS (1987b), quanto nos textos de Evita vive e outras prosas (2001) bem como nos ensaios do autor, interessa-nos verificar a intensidade com que os corpos - incluindo o de Néstor Perlongher - transitam no contexto de uma "[...] truculenta blitz contra os gays [...]" (1987b, p. 64), cujos desejos 
são atravessados pelo controle e assepsia instaurados pelos dispositivos tanto médico quanto de espetacularização midiática. O trabalho se desenvolve, basicamente, tendo em vista duas direções: por um lado, a leitura e análise da crônica "A prisão de Antônio Chrysóstomo", que Adrian Cangi reuniu em Evita vive e outras prosas (2001); por outro, a discussão acerca das problemáticas inseridas em $O$ negócio do michê: a prostituição viril (1987), cuja radicalidade confirma o que na crônica já tinha sido previsto: a ameaça ao desejo através das constantes blitz e perseguição a que foram submetidos os homossexuais, ao longo dos anos 80. Discutimos, ainda, a obra escrita por Antônio Chrysóstomo, Caso Chrysóstomo: o julgamento de um preconceito (1983), que não só reúne os autos do longo processo pelo qual passou o jornalista, como também serviu de ponto de partida para que o escritor publicasse a peça autobiográfica "Olho no olho: $(\mathrm{O}$ show da Tranca Dura), em que menciona sua experiência no cárcere.

No quarto capítulo dedicamos nossas análises às antologias Hule, Aguas aéreas e El chorreo de las iluminaciones. Interessa-nos considerar a torção temática que perpassa as três últimas obras do poeta: do trottoir pelas chamadas zonas da "baixa prostituição" o leitor passa a reconhecer aspectos de ordem mística e espiritual, que denotam uma espécie de ascese dos personagens. Estas análises evidenciam não só o protagonismo que o corpo adquire, enquanto tropo sensorial por excelência, como também revelam a errância do sujeito poético, os desajustes entre o corpo e el mundo de las modas para aquele que "renguea" "el encarnado pie", "los pegasos" ironiza o poeta, aquele que avança e atraca "en la remolina de los pliegues". A estes elementos relacionamos ainda a fase terminal da poética perlongheriana: por um lado, o êxtase e o "Centro Eclético de Fluente Luz Universal Flor das Águas" - experiência da qual derivam os poemas de Aguas aéreas -; por outro, o decesso sob cuja textura elíptica se encerra a insubmissão 
desta escrita, como "[...] num fim de tarde, garoento, lendariamente paulistano [...]" (BAPTISTA, 2001, p. 120).

Com estes capítulos, portanto, pretendemos evidenciar as cartografias corporais em trânsito, cuja noção derivada da filosofia pós-estruturalista enfatiza o método de trabalho nitidamente explorado por Néstor Perlongher na escrita de seus poemas, ensaios, contos, crônicas e artigos. Método que não funciona como simples assunção de procedimentos e técnicas, pois: "mais que mapeamento físico, trata de movimentos, relações, jogos de poder, enfrentamentos [...], lutas, jogos de verdade, enunciados, modos de objetivação e subjetivação [...], práticas de resistência e de liberdade" (PRADO FILHO \& TETI, 2013, p. 3) ${ }^{10}$.

A cartografia, neste sentido, revela a ação política e estratégica do escritor, segundo o qual os territórios corporais funcionam em confluência. O território surge então: "formando uma rede móvel, conectando pontos e posições. São linhas que [...] não param de se remeter umas às outras" (Idem, p. 7), como num rizoma. O rizoma, diriam Rogério Haesbaert e Glauco Bruce (2002, p. 4): “é a cartografia”, ou seja, é uma espécie de teoria das multiplicidades, "voltado para uma experimentação ancorada no real, aberto, desmontável, reversível", que "comporta componentes heterogêneos" (Idem).

\footnotetext{
${ }^{10}$ Não é nosso interesse discutir stricto sensu a dicotomia amplamente debatida pela crítica entre cartografia tradicional e cartografia social. Para isso, sugerimos a leitura de um artigo esclarecedor: "A cartografia como método para as Ciências Humanas e Sociais", cujos autores, Kleber Prado Filho e Marcela Montalvão Teti (2013), explicitam as particularidades predominantes numa cartografia tradicional e social. Aquela, amplamente vinculada ao campo de conhecimento da geografia, logo: "fundada em bases matemáticas, estatísticas, contando com instrumentos e técnicas sofisticadas" (2013, p. 3). Esta, relacionada aos encontros, articulações e movimentos inerentes às Ciencias Humanas e Sociais, segundo a qual: "a cartografia $[\ldots]$ não se refere a territórios, mas a campos de forças e relações: diz mais respeito a movimentos do que propriamente a posições fixas" (Idem, p. 4).
} 
Adentramos, assim, ao território de solo movediço da escrita perlongheriana: tão instável quanto desinterditado. 


\section{Capítulo I - Instabilidades topográficas, genéricas e formais}

\subsection{Prolegômenos a uma cartografia nômade}

Instabilidade e fragmentação operam como importantes dinâmicas da prosa e poética perlongherianas. Tanto os desdobramentos temáticos quanto de estilo assumidos pelo escritor revelam a adoção de aspectos que distoam de uma série de discursividades legitimidas socialmente. Néstor Perlongher exerce, neste sentido, uma escrita não só insumbissa ao mesmo tempo que pouco condescendente. A aposta em valores hegemônicos, podemos afirmar, representam um capítulo praticamente ignorado nesta estética, dado que não só atenua a possibilidade de que se entenda a escritura perlongheriana como processo de decomposição e turbulência, como também ignora suas qualidades enquanto "organismo palpitante” (ROSA, 1996, p. 40) de renovação estética.

A identificação de zonas fronteiriças entre os processos históricos e a instabilidade que suscitam permite que nos aproximemos da escrita perlongheriana, sobretudo se considerado o trabalho desenvolvido em Austria-Hungría (1980) e Alambres (1987). Nestas obras revelam-se o debate político-performativo do poeta, bem como os posicionamentos assumidos durante os anos 70, decorrentes especialmente de sua participação e diálogo com importantes movimentos anarquistas/trotskistas, tais como: Movimiento de Liberación Sexual - SEXPOL; Movimiento de Liberación Feminista MLF e, de modo mais contundente, sua atuação na Frente de Liberación Homosexual FLH. Neste primeiro movimento de nossas análises duas questões tornam-se imprescindíveis: por uma parte, indagar em que medida a categoria de instabilidade explicaria as múltiplas turbulências que formam parte do verso e da prosa perlongherianos; por outra parte, responder à seguinte pergunta: afinal, é possível 
escrever poesia após a barbárie, sobretudo se considerarmos que a escrita perlongheriana estabelece espaços de contiguidade entre a experiência verbal e o elemento histórico?

\subsubsection{A instabilidade como estratégia de escrita}

Propomos a categoria de instabilidade como estratégia de escrita que contempla os desdobramentos formais e temáticos desenvolvidos por Néstor Perlongher. Em sentido estrito, a categoria não parece ajustar-se aos sinônimos "vulnerabilidade", "fragilidade" ou "inconsistência", antes, refere-se aos processos que sugerem variabilidade e mudança enquanto procedimentos criativos e fecundos. O termo em questão sugere uma espécie de agressão às formas fixas e impermeáveis, através das quais se desenvolvem os processos de estagnação da vida. Outro aspecto importante vincula-se ao fato de que a instabilidade pressupõe o estabelecimento de novos territórios, constituindo, com este, eventos concomitantes e indissociáveis. Em Néstor Perlongher a categoria assegura e confirma os múltiplos fluxos constitutivos da escrita: de certo modo, o enunciado barroco dinamita as formas fixas e particulariza o estilo do autor; por outra parte, Néstor Perlongher seleciona temas polêmicos, que nos primeiros poemários, por exemplo, têm como pano de fundo o contexto ditatorial bem como o período de redemocratização política.

Ao apostar em Austria-Hungría como título de sua primeira antologia, Néstor Perlongher manifesta as instabilidades toponímicas inseridas na obra, revelando que, na condição de leitores, estamos à deriva nesta poética da indiscernibilidade. Com AustriaHungría (1980) $)^{11}$, cuja escrita se deu nas interseções de "hablas argentinas", tal como

11 Vale mencionar que Austria-Hungría (Tierra Baldía, 1980) pode ser entendida como uma publicação que prenunciava a postura insubmissa do poeta, sobretudo porque, publicada originalmente no início dos anos 80 , tem como pano de fundo um período complexo que compreende não só os anos finais da ditadura 
sublinha Julio Prieto em "Cercanía del escarpe, o de la bajura en Perlongher" (2016), verificamos a impossibilidade de ajuste aos enquadramentos territorializantes, já que, antes, os versos perlongherianos se deslizam, confirmando os processos de dissolução dos territórios: “[...] estamos donde siempre en Perlongher, donde se abisma el sentido [...] superficies exiliadas [...]. Cosa frecuente en Perlongher: liquidación de los lugares, habilidad de las entradas y salidas. Movilización de la poesía como práctica de dispensar el lugar (Idem, p. 261).

Desde o ponto de vista formal, em “Austria-Hungría de Néstor Perlongher: una violencia sexopolítica”, Javier Gasparri (2010) assume que: “[...] Austria-Hungría se construye, en tanto libro, en dos partes que dejan imaginar desde su nombre un encuentro bélico: los soldados (que llegan) y las mariconas que, allí instaladas, se preguntan "por qué seremos tan hermosas". Y, además, el libro, al abrirse, se propone como "escenas de la guerra", como também sinalizado por nós neste trabalho. Para o autor, estas "escenas de la guerra" operam:

Funcionando casi como didascalias, esas huellas o inscripciones paratextuales "abren las escenas" de lo que se va a ver: una guerra de cuerpos, de géneros, de voces, que se entrecruzarán de un modo permanente y que, como toda guerra, exhibirá una violencia inaudita. (GASPARRI, 2010, p. 2320).

Austria-Hungría coloca em cena a violência sexual, uma violência que "penetra los cuerpos", como sinaliza Javier Gasparri.

militar argentina como também contempla os processos que introduziriam a redemocratização política no país. Por outra parte, nesta pesquisa optamos por trabalhar não com a respectiva versão, mas sim com a edição que consta em Poemas Completos 1980-1992, editada e prologada por Roberto Echavarren e publicada em 1997 pela Editora Seix Barral. 
O primeiro poema, "La murga, los polacos", apresenta inflexões que revelam uma espécie de perigo iminente: desabamento de geografias instituídas, cuja principal extensão, para falar com Gilles Deleuze e Félix Guattari, ocorre por meio de desterritorializações criadoras, pautadas em constantes exercícios de destruição e desentroncamento dos significantes e significados linguísticos. Logo de início, enfatizamos que o "Vístula" não pode ser interpretado em sentido literal, já que, antes, o valor expressado opera metonimicamente, admitindo a interpretação de que este é o Rio da Prata, onde verificamos a poesia desconcentrando-se em seu "lodoso estuario", como diria o próprio poeta:

\section{LA MURGA, LOS POLACOS}

Es una murga, marcha en la noche de Varsovia, hace milagros con las máscaras, confunde a un público polaco Los estudiantes de Cracovia miran desconcertados: nunca han visto nada igual en sus libros No es carnaval, no es sábado no es una murga, no se marcha, nadie ve no hay niebla, es una murga son serpentinas, es papel picado, el éter frío como la nieve de una calle de una ciudad de una Polonia

lo que no es decir que no haya sido, o aún que ya no sea, o incluso no esté siendo en este instante Varsovia con sus murgas, sus disfraces sus arlequines y osos carolina con su célebre paz - hablamos de la misma la que reina recostada en el Vístula el proceloso río donde cae la murga con sus pitos, sus colores, sus chachachás carnosos produciendo en las aguas erizadas un ruido a salpicón que nadie atiende puesto que no hay tal murga, y aunque hubiérala no estaría en Varsovia, y eso todos los polacos lo saben. (1997a, p. 23). 
A murga, enquanto gênero musical, retoma o conceito de carnavalização proposto por Mikhail Bakhtin, cujo principal debate - resguardadas as peculiaridades cronológicas, já que as análises bakhtinianas concentram-se em aspectos estruturantes e inerentes à conformação do cotidiano medieval -, consiste na percepção de que a existência condensa duas perspectivas: por um lado, a vida privada, encerrada no espaço da casa e sobredeterminada por uma série de regras e protocolos; por outro, a vida atrelada ao espaço público.

Esta segunda forma de vida caracteriza-se pelos processos de carnavalização, sendo concebida como território que justifica a suspensão das normas, leis e hierarquias, isto é: a dissolução de máximas inerentes à vida cotidiana. Em "La murga, los polacos" nota-se a interrupção das regras, evidenciando não só a indeterminação como também a arbitrariedade das imagens anexadas pela poeta. Logo na primeira estrofe, o eu poético sugere suas intenções, anunciando que: “[...] con las máscaras confunde a un público polaco". Claudiana Soerensen, em "A carnavalização e o riso segundo Mikhail Bakhtin" (2011), assinala que o linguista russo:

[...] categoriza a máscara como objeto o qual traduz 'a alegria das alternâncias e das reencarnações, a alegre relatividade, a alegre negação da identidade e do sentido único, a negação da coincidência estúpida consigo mesmo;' [...]. Esse objeto [...] encobre o rosto e, assim, disfarça, dissimula, fornece outra identidade ao seu usuário, diluindo o 'sentido único' e relativizando a verdade identitária [...] (2011, pp. 328329 ).

Nota-se, com isto, que entre as múltiplas possibilidades fornecidas pelo conceito bakhtiniano, a relativização manifesta questões que dialogam com uma das principais opções teóricas do escritor argentino: o devir, cuja base filosófica é discutida por Gilles Deleuze e Féliz Guattari em Mil platôs (2012b). 
Segundo os filósofos, o conceito contrasta com as formas dominantes que cumprem papéis disciplinares em nossa sociedade. Afirmam, além disso, que todos os devires estariam inevitavelmente atravessados pelo devir-mulher, sendo este, portanto, "[...] a abertura e a chave para os outros devires (criança, animal, vegetal, mineral, imperceptível) porque é o mais próximo do binarismo fálico" (SANTINI; CAMELIER, 2015, p. 105). Vale mencionar que, a contrapelo dos conjuntos e binarismos molares, isto é, majoritários, que consistem em formações e estratificações opressivas; o devir-mulher opera em um nível molecular, ou seja, minoritário, e não diz respeito ao contrassenso que o define pelo indicativo numérico, tendo em vista que o minoritário é o seu principal argumento. Antes, o devir-mulher refere-se tanto aos movimentos “[...] para fora das estruturas sociais de dominação" (Idem), quanto à distância que estabelece com a máxima dominante, conforme assinalam Rose Marie Santini e Joana Camelier (2015). Gilles Deleuze e Félix Guattari apontam que o devir-mulher sinaliza a chave para a transformação e revolução daquilo que somos. Santini e Camelier apontam que para os filósofos, “[...] libertar-se da ordem dominante é a grande motivação ético-política que pode desencadear movimentos para além destas estruturas”. (SANTINI; CAMELIER, 2015, p. 105).

Neste sentido, os movimentos provocados no poema "La murga, los polacos" operam como processos de instabilidade que focalizam o "para fora" das estruturas dominantes, que revelam o espaço público, representando o devir de “[...] la que reina [...] recostada en el [...] proceloso río", que antes é o Rio da Prata dominado pela licenciosidade, que o Vístula propriamente dito. Antes, é rio no qual “[...] cae/ la murga con sus pitos, sus colores, sus chachachás carnosos". Em "La murga, los polacos" não estamos em Varsóvia, sobretudo porque o topônimo sugere uma espécie de manobra 
poética que desloca o leitor a uma multiplicidade de lugares, dentre as quais o "lamacento" Rio da Prata - de onde Néstor Perlongher convoca a lepra creadora bonaerense, isto é, o enunciado barroco que assume um lugar maior ao longo de sua produção.

Este poema não só inaugura a poética do autor, colocando em evidência os (des) ajustes e agenciamentos que compõem seu processo de produção escrita, como também revela o oximoro perlongheriano por excelência: uma introdução com ares de fim de festa, para retomar Kamenszain. O que significa "Escenas de la guerra" e "Llegan los soldados" - epígrafes com as quais Perlongher convoca seus leitores -, senão a escolha poética daqueles que "[...] en el Carnaval de Ciudad Vieja/ entre los negros descoloridos, con fastidio/ sólo pensaban en el sexo sexo sexo" (PERLONGHER, 1997a, p. 24), optando pelo riso e pela gargalhada ante o aborrecimento, o enfado e o cansaço? Se como apontam Gilles Deleuze e Félix Guattari: “A música tem sede de destruição, todos os [...] tipos de destruição [...]" (2012b, p. 105), observamos que a máquina sonora perlongheriana, isto é, o poema propriamente dito, confirma o sentimento que experimenta o leitor: o de estar à deriva.

No ensaio “El canto del cisne de Néstor Perlongher” (1996), Tamara Kamenszain sugere “[...] un Darío on the road $[. .$.$] ” perlongheriano, considerando “[...] las múltiples$ peregrinaciones que emprendió con su obra (p. 202). Por outra parte, podemos afirmar que os movimentos de instabilidade empreendidos pelo poeta não se restringem tão somente ao mapeamento topográfico, conforme revelado na leitura de "La murga, los polacos”. Para Tamara Kamenszain, na vocação peregrina que antecipa o enunciado perlongheriano “[...] se disimula [ também] el nomadismo del deseo homosexual [...]” e 
todos os aspectos identitários inscritos neste debate, tal como o próprio autor discute em "El deseo de unas islas": "En esa misma ciudad donde fui tratado de promarica y prochongo, un día hice un pequeño escándalo al cruzar una calle inundada a los saltos; debió haber sido muy gracioso, porque unas mujeres se pusieron a gritar: nãi é homem nem mulher" (PERLONGHER, 1997b. p. 187, grifos nossos).

Se os deslocamentos provocados pela abordagem perlongheriana desestabilizam determinadas geografias e discursos, a partir dos quais se identifica a perturbação da norma, de igual modo o poeta exprime seu incômodo ante as problemáticas relacionadas à identidade. Retomando o caso Ilhas Malvinas, diz o autor de Prosa plebeya: ensayos (1980-1992):

El extinto FLH argentino publicó en el penúltimo número de su revista Somos (antes del allanamiento policial final) un editorial titulado: "Los homosexuales no tenemos patria". Giraba en torno de la idea de que los mandatarios, los discursos del poder, se dirigían, cuándo más, a los "hombres y mujeres de la patria", pero nunca a los "homosexuales de la patria". (1997b, p. 186).

Em "El deseo de unas islas", Néstor Perlongher contesta a insistência pela busca de uma identidade gay, que entre outras problemáticas incorre na “[...] domesticación por vía de la normativización, de la adaptación [...]” (Idem, p. 188). Quando trata da questão homossexual o escritor redireciona o debate como forma de “[...] preguntarse por el tono de solemnidad que impregna algunos discursos liberacionistas [...]” (Idem): “[...] a veces me pregunto para qué tanto empecinamiento en agruparlos ${ }^{12}$ en identidades

\footnotetext{
${ }^{12}$ A forma pronominal, obviamente, refere-se às categorias criadas por distintos grupos liberacionistas, como forma de estabelecer territórios identitários - categorias que o autor propõe como "deslizamientos semánticos" (1997b, p. 187): "homosexual, gay, marica, entendido, chongo, taxi-boy, travesti [...]".
} 
separadas cuando el malandro transa con el borracho, la marica fuma con el maconiero, y la puta hace programa con el transeúnte, etcétera” (PERLONGHER, 1997b. p. 188).

Além destes dois aspectos, os deslizamentos propostos por Néstor Perlongher tanto em "La murga, los polacos" quanto no que diz respeito à identidade, aplicam-se a um terceiro elemento: ao enunciado poético e ensaístico em sentido estrito. Julio Prieto (2016) assinala que, partindo de incursões em distintas materialidades textuais - poéticas, ensaísticas, etc. -, observa-se uma espécie de "desterritorialización de lo literario" (p. 257). De modo menos sistemático, Christian Ferrer e Osvaldo Baigorria já haviam sublinhado tais instabilidades, sobretudo quando questionaram: "Por qué interesaría la prosa de un poeta?” (1997, p. 07). Julio Prieto sugere que em Néstor Perlongher lidamos com:

[...] "una poética del abandono" - una práctica de des-escritura de una determinada trama de hábitos discursivos, sociosexuales y literarios [...] una política del abandono: una práctica del abandono de los lugares normados e instituidos de la subjetivación de sí y devenir otro que enlaza con el pensamiento deleuziano de la deriva [...]. (Idem, p. 259).

Neste sentido, considerando que a instabilidade predomina como estratégia formal e temática em Néstor Perlongher, seria adequada a pergunta: afinal ¿adónde estamos? Estamos na dissolução dos territórios, ou como o próprio poeta/ensaísta responderia em “69 perguntas a Néstor Perlongher” acerca dos traços definidores de seu estilo:

Arriesgo: [estamos en] cierto embarrocamiento (no decir nada "como viene", sino complicarlo hasta la contorsión) amanerado o manierista y, al mismo tiempo, una voluntad de hacer pasar el aullido, la intensidad. Una forma rigurosa [...] para una forma en torbellino. Y siempre el desafío de perderme en las maromas de las letras, efluvio saltarín, en el límite de la insensatez, del sinsentido [...]. (PERLONGHER, 1997b, p. 15 , grifos nossos). 
Nota-se, desse modo, que os textos perlongherianos admitem uma série de desdobramentos que revelam não só uma geografia instável e em constante redimensionamento semântico como também perpassada por distintas redes conceituais. No seu exercício de escrita os significados simbolizam valores ondulatórios, instáveis e, amplamente, difusos.

O debate acerca das dimensões toponímicas, genéricas e formais - enquanto eventos performáticos operados por Néstor Perlongher -, implica aberturas que extrapolam o caráter puramente denotativo do signo. A noção de performatividade acomoda a materialidade poética, tornando-a altamente complexa. Para Antonio Candido, “[...] o poeta 'cria' um mundo seu" a partir da forma como manipula as palavras, de modo a “[...] refazer o mundo pela imagem" (1996, p. 67).

Através dos processos de refacção do mundo por meio da imagem, as palavras legitimam arranjos variáveis “[...] adaptando-se não somente às necessidades do ritmo, como também adquirindo significados diversos conforme o tratamento que lhes dá o poeta" (CANDIDO, 1996, p.69), o que significa dizer que o poeta manipula de forma astuta não só os aspectos preponderantes da linguagem corrente, direta, como também aquilo que é intrínseco à linguagem dita figurada: transferências, distorções, transposições de sentido, metaforizações, etc. Em Néstor Perlongher notamos não só o estilhaçamento e subversão por meio de versos "[...] totalmente desfigurados [...]" (CANDIDO, 1996, p. 61), como também observamos dissonâncias e invulgaridades: sonoras, sintáticas, semânticas, chegando, inclusive, aos processos de desintegração e justaposição, que tendem não somente ao acúmulo de imagens e símbolos, como também confirmam a rebeldia retórica de seus textos. 


\subsection{Instabilidade e produção de sentido}

Outra face da rebeldia retórica de Néstor Perlongher vincula-se às reflexões que Ana Porrúa apresenta em Caligrafía tonal: ensayos sobre poesía (2011): "la puesta en voz de la poesía". Na introdução à sua obra, Ana Porrúa (2011) indaga-se quanto a duas grandes proposições, presentes quase como uma obsessão ao longo de sua carreira: “[...] qué se escribe en la poesía y cómo se lee” (p.15). A autora sugere que às possibilidades de resposta soma-se a percepção das limitações inerentes ao processo hermenêutico. A este aspecto, portanto, articulamos o contato com a escrita de Néstor Perlongher, sobretudo porque como assinalado por Roberto Echavarren no prólogo a Poemas completos (1980-1922):

En la poesía de Perlongher, y hemos de vivir un tiempo hasta digerirla, la seducción de lo monstruoso [...] despliega un fondo pretendidamente inconfesable que no es sino la excusa para la investigación desenfrenada de gozar con las palabras. La sobreabundancia es compatible con el doble o triple sentido, la aliteración y la deformación de los significantes". (1997, p. 07).

Através de Ana Porrúa e Antonio Candido (1996) notamos um elemento sobressalente no que se refere à arquitetura da voz, ou como sugere a autora: la puesta en voz da materialidade textual, sobretudo poética. Para Candido: “[...] certos psicólogos e foneticistas sustentam que a leitura é acompanhada de um esboço de fonação (ação ideomotora) e de audição, de tal modo que nós representamos mentalmente o efeito visado" (CANDIDO, 1996, p. 26, grifos nossos). O que significa dizer que a complexidade a que se subordina um poema, por exemplo, pode ser verificada nos conflitos que surgem quando o leitor submerge no construto poético propriamente dito, fazendo da assimilação das unidades de fonação o desenho de uma escrita em discordância com aquilo que expõe o eu poético. 
Em alguns poemas perlongherianos, por exemplo, observamos que o poeta não se encarrega de questões políticas de forma estrita, muito embora estas reflexões integrem o debate e confundam o leitor, que interpreta o enunciado a partir de uma transparência traiçoeira, conforme sinalizado por Roberto Echavarren:

[...] El poema no se ocupa de política. La política, reinventada [arrebentada, diríamos], emigra [...]. Los personajes de la historia que aparecen en la obra de Perlongher no son ni héroes ni villanos. Son apenas la oportunidad de jugar una broma, un reconocimiento extrañado, de traducirlos en el idiolecto de un mutante, de 'alucinar'. (1997, pp. 10-11, grifos nossos).

No capítulo "La puesta en voz de la poesía”, Ana Porrúa (2011) expõe que, na condição de leitores de textos poéticos, na transposição do texto lido ao texto escutado, a arquitetura do processo interpretativo se estabelece tendo em vista uma escuta imaginária, que simboliza a escuta “[...] que nosotros tenemos del poema antes de oírlo como articulación vocal” (2011, p. 152):

Nuestra escucha, entonces, puede ajustarse o no a la puesta en voz de un poema y, por otra parte, lo que se pone en funcionamiento allí es una sumatoria de escuchas: mi escucha más la escucha, por ejemplo, de Alejandra Pizarnik recitando Escrito con un nictógrafo de Arturo Carrera, al que su voz quemada y a la vez solemne envía de algún modo hacia el pasado un texto absolutamente experimental [...]. La puesta en voz, de este modo, agrega una serie de escuchas al texto, o una serie de lecturas y, entonces, genera un espacio crítico en relación al original [...]" (PORRÚA, 2011, pp. 152-153, grifos nossos).

Em sentido estrito, Ana Porrúa sinaliza que na posta em voz do texto poético elimina-se a previsibilidade da audição: "En este sentido, habría territorios de mayor estabilidad - más cerrados [...] - y territorios más lábiles, donde es posible escuchar de modo nuevo" (Idem, p. 155). 
Em “Cadáveres” (PERLONGHER, 1997a, pp. 109-123) recaímos na dissonância enfatizada por Ana Porrúa, principalmente porque no quarto capítulo de Caligrafía tonal: ensayos sobre poesía analisa "Eva Perón en la hoguera", de Leónidas Lamborghini. A cena considerada pela autora argumenta em favor do estabelecimento de relações entre a leitura de um determinado poema e a escuta imaginária que esta leitura convoca ${ }^{13}$. As disjunções radicadas no processo de escuta são tão relevantes, que acabam expressando modulações e intensidades - inclusive suprassegmentais - extremamente peculiares. Como no caso de Lamborghini, em Néstor Perlongher “[...] se escucha una pista sonora a la que se le baja y se le sube el volumen permanente, y a la vez se retrocede en algunos puntos, se escucha la voz de alguien amordazado de manera repetida (y sin mordaza luego) que sin embargo nunca abandona su tono [...]" (PORRÚA, 2011, p. 170): o tom e o volume de "una gritería" inapelável, o tom de "una loca argentina".

O leitor do enunciado perlongheriano resvala nas estrias semânticas de uma escuta previsivelmente estruturada, sobretudo porque muitas vezes seu processo de escuta se revela transtornado por uma série de influências: como as históricas, por exemplo; e ajustado aos enquadramentos de uma leitura hegemônica: “[...] aquello que es puro fragmento en la lectura, que cuesta recomponer, parece un texto liso, entendible, que transmite un mensaje más o menos directo" (PORRÚA, 2011, p. 171). A compreensão do enunciado poético revela, desse modo, fenômenos em constante instabilidade. Nesta poética os valores nunca serão absolutos nem contíguos, ou como diria Nicolás Rosa em

\footnotetext{
${ }^{13}$ Sobre este aspecto, vale sublinhar as dimensões que a ideia de prosódia assume no enunciado perlongheriano. Poderíamos sugerir pelo menos três: uma primeira que diferencia o ritmo do poema, que incorpora determinada prosódia; uma segunda que tende a interferir na escuta imaginária de um poema específico e, por fim, uma terceira dimensão estritamente relacionada à leitura pública que Néstor Perlongher realiza de alguns de seus poemas, como no caso de "Cadáveres" - cuja prosódia não é, obviamente, a mais legítima para época, demonstrando com isso o caráter insubmisso em que aposta o escritor.
} 
"Una ortofonía abyecta": "Una de las características más bellas de la poesía de Perlongher es el poema como organismo palpitante, la figura late como un ser vivo en su propia decomposición" (1996, p. 40), explicitando constantes turbulências e minando o nódulo global de sentidos fixos ou previamente determinados.

\subsection{O "grão da voz": escucha imaginaria e produção de sentido}

On dira que la chair de l'audible est plus dense, plus opaque, plus érotique, que la chair du visible, toujours plus structurée, plus transparente, plus cérébrale. La magnificence de la voix et de son grain, du travail de la gorge dans la sonorité vocale, comme en parle Roland Barthes, nous fait comprendre pourquoi le sonore est plus proche du corps et du bruissement de la vie: l'audible porte de rythme sourd des corps, le temps des existences, la densité des affects.

(H. Parret apud MENDES, 2012, p. 1).

Apostar em um determinado padrão como valor absoluto do enunciado poético,

como se presume a partir do conceito de escucha imaginaria, atenua o potencial modalizador da linguagem verbal. Sobre esta questão, Ilse Maria da Rosa Vivian afirma que:

No campo literário [...] determinados discursos [...] tendem a tratar o texto como entidade de voz absoluta, manifestos por construções de linguagem que visam à expressão de uma única verdade e, por conseguinte, à neutralização do leitor [...].

A linguagem não solicita apenas o que ela mesma produz e, de outro modo, não produz apenas o que lhe é solicitado. Ela é transgressão de si mesma, quando, no ato da leitura, é dissimulação, desconstrução, pluralidade, descontinuidade, ou seja, quando lhe escapam por entre sentidos rastros que fogem às estruturas internas ou a qualquer significado que lhe possa ser imposto por alguma lógica absoluta". (2015, pp. 26-27).

Com efeito, é importante assinalar a instabilidade que prevalece na correspondência plano do conteúdo/ plano da expressão. Em Néstor Perlongher, a 
intensidade dos aspectos suprassegmentais recuperados na leitura que o autor faz do poema “Cadáveres" - dicção/ entonação, ritmo e acentuação -, cesuras, retenções, fluxo da fala/ taxa de elocução (como numa espécie de economia do enunciado poético) -, repercute tanto na atualização de nossa escuta quanto no estabelecimento de uma ruptura tonal $^{14}$ : o plano vocal, seus resíduos sonoros bem como as imagens que se descolam desta leitura, apresentam um corpo, de onde emerge como material sonoro (SOARES, 2014, p. 25), o corpo do próprio poeta. Adrián Cangi questiona: “Una voz es apenas una voz?” (2000a, 14). Para o crítico argentino: “[...] Una voz es un vehículo productor de resíduos, un bloque de resonancias corporales, un efecto de estilo que conecta la biografía como mitología personal a las pulsiones como expresión. Em Néstor Perlongher podemos falar em termos de diferença entre performance e simples leitura individual.

[...] para que a voz seja percebida como estética, como qualitativa, implica reconhecê-la como de natureza plenamente corporal: "a significância da voz precede e transcende o sentido das palavras proferidas, ela reside sobretudo no que há de musical na voz, em sua tonalidade, sua cor e seu timbre, em seu espasmo rítmico. (MENDES, 2012, p. 15).

Como afirma Conrado Moreira Mendes (2012): voz e corpo são instâncias indissociáveis, estabelecem entre si uma relação erótica em que a tonalidade passa a exprimir o estado passional e a significância: a expressão porte presence et absence. Apoiado nas leituras de La voix et son temps, de Herman Parret, Conrado Moreira Mendes aponta que

A marca tonal exprime [...] a subjetividade profunda e sua presença no nível da manifestação auditiva, presença do sujeito que convida à apreensão de sua essência, à escuta de sua especificidade. No caso da comunicação das emoções/paixões por meio da voz, os afetos são

\footnotetext{
${ }^{14}$ Cf. "O grão da voz". Em "O grão da voz" (1990, p. 245), Roland Barthes destaca o fenômeno, quando assinala que a ruptura tonal é uma formidável proposição da modernidade.
} 
comunicados não por um conteúdo semântico, mas pela qualidade do significante, isto é, o conjunto de propriedades fonoestéticas da mensagem [...]. (Idem, p. 18).

Na leitura pública que Néstor Perlongher realiza de "Cadáveres"15 - no hall do Teatro General San Martín, e gravada em fita cassete -, observa-se que, pelo menos inicialmente, o poema sugere características de uma farsa. Nota-se, entretanto, que a inflexão empregada pelo autor excede os limites de uma narração burlesca. O risível se converte, neste sentido, em ferramenta que configura as múltiplas modalizações constitutivas da materialidade poética - a contrapelo do que ocorre em uma escucha imaginaria hegemônica. A instabilidade causada pela leitura que realiza o poeta confirma que o leitor continua à deriva no processo de compreensão textual: como sublinha Roland Barthes em “O grão da voz”, o leitor deve buscar: “[...] algo que está além (ou aquém) do sentido das palavras" (1990, p. 239). Diz Domingos Carvalho da Silva: "Gérard Genette, num ensaio sobre o Estruturalismo e a crítica literária, assinala que Roman Jakobson, num estudo de 1923 (sobre o verso checo), já revelava “une relation entre la valeur prosodique d'un trait phonique et sa valeur signifiante" (1989, p. 96, grifos nossos), revelando com isto a participação acústica no processo de significação poética.

\footnotetext{
15 "Néstor Perlongher escribió este poema en 1981, cuando emprendía su viaje definitivo a San Pablo. Más tarde se refirió a él como un 'típico poema de escuela, de esos que se recitan en los actos', que abre como una 'rima tonta' (Bajo las matas/ En los pajonales/ Sobre los puentes/ En los canales/ Hay Cadáveres) y 'a partir de allí empieza como un torrente. La escritora María Moreno sostuvo que sintió que la dictadura militar había terminado cuando escuchó a Perlongher recitar el poema en el hall del Teatro General San Martín". Disponível em: https://malba.org.ar/perlongher-cadaveres/?=diario. Acesso em fevereiro de 2019.
} 
A intervenção voluntária do poeta, logra, por um lado, a inserção no gênero farsa ${ }^{16}$, como uma comédia de baixo nível, com poucos personagens ${ }^{17}$, tom burlesco e grotesco; revela, por outro, uma multiplicidade de vozes, isto é, de caligrafias tonais, que se desterritorializam, fazendo do poema um território polifônico por excelência:

[...] en el poema hablan. Porque Perlongher trama su poema hilando sus versos con frases de otros, voces escuchadas al pasar, fragmentos de conversaciones. El texto como un tejido social. En "Hay cadáveres" más que un yo lírico, habla una colectividad. Voces que en el poema hablan sobre cualquier otra cosa: tales son las conversaciones entre quienes se saben vigilados, observados, escuchados del otro lado de la pared $^{18}$.

Durante sua leitura, Néstor Perlongher convoca os “cadáveres" para estas cenas: convoca não só distintas vozes como também desobstrui os caminhos sem saída da história. O poema converte-se em gênero teatral, falta ao poeta somente o vocativo "senhoras e senhoras" para que o introito confirme dita adesão. A justaposição de cenas e quadros auxiliam no estiramento do discurso, sobrecarregado pela densidade de assonâncias. Uma espécie de cansaço crônico se instaura durante a elocução - expedido principalmente pela regularidade das aliterações em $/ m /$ e $/ n /-$, fazendo com que o

\footnotetext{
${ }^{16}$ Esta relação se torna interessante à medida que, recuperando a gênese da farsa, verifica-se que o gênero tendia para a crítica dos costumes e do caráter da sociedade da época, daí a relevância do caráter cômico predominante. Mais interessante ainda o fato de que o riso que se pretende alcançar com o gênero farsesco trata de não ser nem didático, nem moralizante. Antes, cotidiano, vícios e virtudes que conformam a realidade social são examinados, a fim de identificar os aspectos mais convenientes e interessantes para o escritor.

${ }^{17}$ Sugere-se a existência de diferentes personagens como um efeito do histrionismo provocado pelo poeta. Este fenômeno só é possível de ser assegurado devido às modalizações vocais apresentadas no decorrer da leitura de Perlongher. Outro dado importante diz respeito ao fato de que Néstor Perlongher emprega não somente qualidades sonoras específicas, como também expressões oriundas de outros idiomas. O poeta faz com que a língua - e por consequência seu leitor/ ouvinte - enloquezca.
}

18 FABRE, Luis Felipe. "No hay palabras: 'Hay Cadáveres"”. Disponível em: http://laboratoriopoetico.blogspot.com/2008/12/no-hay-palabras-hay-cadveres-luis.html. Acesso em julho de 2018. 
desânimo toque leitor e ouvinte de modo indiferençado: esta voz que emerge como expansão do corpo é capaz de tocar-nos.

Nos blocos em que se verificam estes aspectos nota-se, ademais, que o plano da expressão oculta o do conteúdo. A escuta - refém do timbre, desacelerações, deslocamentos dos acentos, subidas e descidas do volume entonacional do poeta - precisa ser reiniciada, retomada, sob o risco de não se perder por entre a volúpia e os abismos estruturantes do poema. Além de desestabilizar texturas lineares previstas no interior da escuta imaginária por meio da ironia, Néstor Perlongher comprova que a voz "[...] é portadora de significações independentes do que é veiculado pela linguagem verbal" (MENDES, 2012, p. 2), isto é, a voz é mediadora e modeladora na constituição e produção de sentidos: "O grão é o corpo na voz [...] na mão que escreve, no membro que executa" (BARTHES, 1990, p. 244).

Muito embora, em alguns momentos a voz do histrião provoque o riso, os minutos finais de sua "farsa" geram extremo mal-estar e desconforto: um sentimento de perturbação é instaurado, sobretudo quando Néstor Perlongher apresenta uma série de enumerações espiraladas - garantidas pelo tom e intensidade com os quais emprega sua voz. À esta altura, a tonalidade do poeta, sua caligrafia tonal, permite-nos "fugir" do significado inicial, já que funda em si mesma um valor que escapa ao previamente lido. Nos minutos finais da leitura pública apresentada por Néstor Perlongher, o vaivém e o histrionismo são despejados num prolongamento elegíaco e enérgico da voz do poeta. Escutam-se os assombros do poeta histérico, que grita insistentemente: "Cadáveres, Cadáveres, Cadáveres...". Ao que lhe segue: "No hay nadie?, pregunta la mujer del Paraguay/ Respuesta: No hay cadáveres". 
Por um lado, o clímax da leitura, ademais do caráter de assombro e perturbação expostos no desconforto da performance vocal, diz respeito ao paradoxo instaurado através do verso final "No hay cadáveres". Considerando que a negativa propõe a descontrução de tudo o que vinha sendo arbitrado desde o início, ou seja, a instabilidade e fragmentação que supõem a abolição de terrenos fixos e estáveis. Nas palavras de Luis Felipe Fabre (2005):

[...] la inesperada aparición del "no" supone la abolición del orden que el estribillo "Hay cadáveres" había instaurado a lo largo del poema. Su efecto es retroactivo y todo el texto parece deshilarse en nada. Una estructura se derrumba. A través de la negación un régimen se derrumba, el orden de la tiranía concluye, pero no así el terror. El terror continúa. Va en aumento. Crece. Lo abarca todo. "No hay cadáveres": más que terminar, el texto desaparece: cadáver negado. Queda tan sólo una ausencia brutal. No hay palabras.

Para o crítico, “[...] más que un poema sobre los desaparecidos, "Hay cadáveres" es un poema que asume su desaparición $[\ldots]^{19}$. Por outra parte, deve-se considerar também o fato de que durante a leitura predomina uma pausa considerável logo após a negativa (No /.../ Hay Cadáveres), insistindo deste modo numa outra sorte de ambiguidade: Há ou Não há Cadáveres? Javier Gasparri assinala que “Cadáveres’ es lo que está ausente ('Respuesta: No hay cadáveres') [...] es como un punto de imantación al que nunca se puede llegar cabalmente pero que al mismo tiempo está presente todo el tiempo, en todas partes: como los cadáveres" (2015, pp. 12-13), como a instabilidade experimentada pelo leitor.

\footnotetext{
${ }^{19}$ C.f. nota 18.
} 


\section{4. É possível escrever poesia após a barbárie? A matéria poética como mediação entre o homem e o mundo}

A barbárie, radicada nos contextos de exceção, há muito foi convertida em metáfora da era moderna, sendo explorada em uma multiplicidade de debates ao longo de todo o século XX: históricos, filosóficos e psicológicos. Para Edson Teles e Vladimir Safatle (2010) a literatura completa o quadro de análise no interior das reflexões sobre os processos de luto e de acolhimento da violência pela memória. Na obra organizada pelos filósofos, $O$ que resta da ditadura: a exceção brasileira, somos convidados a pensar “(...) por que os corpos de seus mortos [considerando o caso específico da ditadura brasileira] ainda não foram acolhidos pela memória”, cuja reflexão nos faz ingressar em uma dimensão extremamente perversa ao constatar que: "A história [...] tem maneiras cruéis de ensinar o verdadeiro tamanho das batalhas" (p. 12, grifos nossos).

No que concerne aos aspectos estritamente vinculados à ordem do literário, verifica-se um gesto de insubmissão, já que em determinadas circunstâncias a voz ficcional contrapõe-se à voz hegemônica da história, apresentando-se como um espaço de elocução que mina a pretensa transparência da lógica tradicional, bem como corrói as estruturas referenciais concebidas como tradução de uma suposta "realidade". A poesia, neste sentido, abre espaço para as arbitrariedades, para a dissolução do referente, fazendo com que contracenem razão estética e razão científica. Com a voz poética, por exemplo, lidamos com o agenciamento de vozes ambulantes, nômades, que chegam para dar notícias dos mortos e silenciados: "Tenemos el aval de nuestros muertos" diria Tamara Kamenszain (1988, p. 120). Da experiência do vazio, a poesia brota como uma espécie 
de salvação $o^{20}$ por meio da escrita, e a relação com o "real" se instaura de forma oblíqua e opaca. O real aparece estilhaçado, uma vez que é interpretado como um evento da linguagem - sendo possível, portanto, apenas como acontecimento no interior desta.

Em “Traços literários e filosóficos nos textos” (2009), Jayme Paviani aponta que o tecido poético, a contrapelo dos textos em prosa, assemelha-se aos filosofemas. De acordo com o crítico, a prosa estabelece relações diretas e imediatas com a realidade, sendo mais ligeira e verossímil que a materialidade poética. Deste modo, no interior dos textos em prosa nota-se um dasein menos visceral, ao passo que naqueles ocorre a exacerbação da imagem, o intenso trabalho com a plasticidade visual bem como a diluição e esgotamento da transparência: “Así pues, podemos proponer esta hipotesis de que la imagen arde en su contacto con lo real" (DIDI-HUBERMAN, s/d, p. 1) - o que para Ana Cecilia Olmos (2004), seria uma forma de convocar “[...] uma linguagem em risco, ameaçada de se cristalizar na transparência da comunicação".

Considerando as reflexões de Vilém Flusser (2011), presentes em Filosofia da caixa preta: ensaios para uma futura filosofia da fotografia, observamos que na introdução de sua obra Vilém Flusser estabelece um campo de especificidade das imagens, enquanto “[...] superfícies que pretendem representar algo" $(2011$, p. 15) ao mesmo tempo que prevê certo distanciamento entre estas e as imagens técnicas compreendidas como as imagens que são produzidas por aparelhos e que surgem sobremaneira a partir da "crise dos textos" e do consequente "naufrágio da História"

\footnotetext{
${ }^{20}$ Do grego soteria, o vocábulo faz referência à cura, à redenção e ao resgate, além de ser concebido como uma espécie de antídoto, remédio. De certo modo, parece interessante considerar a poesia como uma espécie de "salvação" ou, conforme assinala Gilles Deleuze em La litérature et la vie (1993), como uma sintaxe em que predominam "[...] des détours nécessaires chaques fois crées pour révéler la vie dans les choses" (Idem, p. 12), principalmente quando os "excessos de realidade" fazem da vida um complexo indefinido e conflituoso.
} 
(Idem, pp. 20-21). No que singulariza as imagens, enquanto superfícies significativas, verificamos dois aspectos relevantes e ambivalentes: por um lado, para Vilém Flusser as imagens configuram atmosferas de mediação nas relações estabelecidas entre o homem e o mundo, à medida que instituem vínculos com o referente; por outro, a imagem é aquilo que confirma a não plenitude e a não transparência do real. Encontramos, assim, um ponto de contato entre imagem e poesia (entre imagem e texto), já que para Vilém Flusser os textos “são [...] mediações tanto quanto o são as imagens" (2011, p.20) - nesta fissura atua o poeta: "Seu propósito é mediar entre homem e imagens", ainda que levemos em consideração que "[...] os textos podem tapar as imagens que pretendem representar algo para o homem $[\ldots] "$.

O exercício de escrita conduzido por Néstor Perlongher insiste na possibilidade de minar e corroer tanto o discurso predominante na história do século $\mathrm{XX}$, quanto aquele previsível em algumas poéticas. A intenção do poeta consolida-se como a de quem faz "con toda deliberación que la lengua enloquezca" (PANESI, 2013, p. 01). Conforme enfatiza Ana Porrúa, nos textos de Néstor Perlongher "Los muertos tienen un espacio 'real' [...] "El lugar de los restos", cujo "[...] movimiento va a contrapelo de toda posibilidad de estabilizar un territorio" (2013, p.01); e, a partir da maneira como dispõe as imagens ao longo de seus poemas, nos damos conta de que se inclina ao tipo de mediação sugerido por Vilém Flusser.

Muito embora Jorge Panesi (2013) discorra sobre uma espécie de recursividade na escrita perlongheriana - especialmente porque Néstor Perlongher "supo hacer una política no sólo con lo suburbano, lo minoritario y lo lumpen, sino que le dio una dimensión poética a lengua de las locas (Idem, p.1) -, em Néstor Perlongher não somente 
a instância verbal passa por um processo de desentroncamento e desterritorialização, uma vez que as imagens selecionadas pelo escritor expressam arquiteturas inesperadas. A escrita perlongheriana tem como uma de suas principais estratégias os processos de desfiguração, sobretudo do ponto de vista formal - como se, ao fim e ao cabo, sua intenção se guiasse pelo desejo de confundir o leitor, deixando-o diante de múltiplas encruzilhadas. Quando escreve, Néstor Perlongher adota uma lengua que "se vuelve loca" (2013, p.01).

Para Jorge Panesi, “[...] las locas nunca pudieron hablar así en la poesía, y los intentos anteriores en toda Latinoamérica se convierten en recatados gestos puribundos y culposos que sólo ensalzan la moral establecida, la trampa cuyo mecanismo se padece [...] (Idem). O crítico sublinha, inclusive, a própria dificuldade da crítica em se relacionar com o enunciado perlongheriano, cujas manifestações - tidas por ele como "programáticas"-, acomodam uma espécie de jargão crítico estável e hegemônico, como se a atividade analítica tivesse sucumbido a uma espécie de força encantatória, desenhando, assim, um caminho menos crítico que diegético.

Para Javier Gasparri, autor de "Poesía y política en Néstor Perlongher” (2012, p. 18), nota-se em Néstor Perlongher “[...] la presencia fuerte de una escritura política, con un claro impulso de intervención (incluso de provocación), al mismo tiempo que una aspiración a nombrar, registrar, la violencia política que le era contemporánea [...]" (Idem, grifos nossos). O crítico sugere leituras que se contrapõem às recepções críticas predominantes acerca da poética e ensaística perlongherianas. É interessante, por exemplo, a análise que realiza acerca de dois poemas específicos: "Canción de amor para los nazis en Baviera" e "Herida pierna". Sobre aquele, expõe um "[...] juego masoquista, 
tentación en la destrucción [...]” (Idem, p. 32), cujos versos expressam o expediente barroco por excelência, o quiasmo. Ou seja, tanto no título que leva o poema, "Canción de amor [...]", quanto nos versos subsequentes, "Oh no no no es cierto que me quieras/ Ay ay ay me dabas puntapiés [...]”, a voz poética garante e entrosa a ironia, o paradoxo e, do ponto de vista semântico, propõe-se uma leitura que traz à tona os delírios da violência política. Para o crítico: "La violencia política se exhibe sexualmente: es el modo de mostrarla a carne viva, perforando los cuerpos" (2012, p. 30). De modo que as imagens produzidas armam um sistema de referências históricas.

Como ressalta Javier Gasparri: "Llegan los soldados" (nazis?) instaura uma cena extremamente complexa, uma vez considerado o contexto histórico e político que Néstor Perlongher assume como ponto de partida de seus primeiros poemas: o termo "soldados", por exemplo, dissimula o cenário bélico que constitue o pano de fundo de suas experiências de escrita: a "[...] violencia política penetra los cuerpos: el poeta canta con Marlene Dietrich [...] Y mientras canta, cuenta: 'Y yo sentía el movimiento de tu svástica en las tripas"” (GASPARRI, 2012, p. 30).

Em "Herida pierna", por seu turno, concordamos com Javier Gasparri quando destaca que: "Alguien enuncia este poema cuyo título nos tiende una trampa basada en una promesa de ajuste semántico al conjunto (estamos en una guerra: es esperable una pierna herida)" (Idem, p. 32). Por outro lado, e abortando uma parcela do valor literal atribuído ao poema, propomos uma leitura centrada no que Julio Prieto considera como “desplazamiento de lo literario" (2016), como forma de não mitigar a força desterritorializante que reside nesta poética. 
O deslocamento proposto constitui-se a partir da leitura não literal do título: "Herida pierna". Com a epígrafe que inicia o poema: "Deseoso es aquel que huye de su madre" (PERLONGHER, 1997a, p. 47) ${ }^{21}$ Perlongher não somente retoma Lezama Lima, principal expoente do neobarroco latino-americano, como sinaliza que desejoso é aquele que foge de sua mãe ${ }^{22}$. O eu poético indaga: "Huyo de la madre de Lezama Lima? La hago pedazos? $\mathrm{Ou}$, antes,

[...] debo adorarla? suplicarla? adosarla?

cultivar el jardín donde se entierra?/ Como liendre en una mata

Oh, ensartarla! (PERLONGHER, 1997a, p. 47).

Neste breve excerto, observa-se que, através da gradação evocada pelas aliterações, a voz poética anuncia um diálogo intertextual como manobra poética e riso zombeteiro ante a mãe lezamesca (a máquina barroca por excelência) - desta com a qual deve-se romper o cordão umbilical, "cerrar las ventanitas" (Idem), assumindo, pois, o enunciado neobarroso como vetor que decanta e vai

[...] metiendo los estiletes en el muslo

para que arda para que mane haciéndole volcar lechoso polvo en la enramada ampliándola estirándola. (Idem).

Por mais que em "Herida pierna" predomine certa desorientação referencial ["Por ella (de él)]: "[...] durante la hora del dolor del calor/ de la sofocación de los gemidos [...]", inerente a toda e qualquer separação/cisão, é que sob "esa masa de tejidos" o "impotente"

\footnotetext{
${ }^{21}$ Em referência ao poema "Llamado del deseoso", publicado em Aventuras sigilosas (1945), de José Lezama Lima.

${ }^{22}$ PERLOGHER, Néstor. Lamê. Tradução de Josely Vianna Baptista. Campinas, SP: Editora da UNICAMP, 1994. (Coleção Matéria de Poesia).
} 
converte-se em produção de potência: "impotente como potente" diria o poeta, cujos enunciados "arbitários" são "flechados pelos estrilos" (Cf. nota de rodapé 11). "Herida pierna" encerra quando a voz poética questiona:

Debo chupar? Mamar? de ese otro seno herido Desangrado con la pierna cortada con la daga En la nalga $[\ldots]$ ser lúcida? ahora, hoy? (Idem, p. 48).

Nota-se, contudo, que - muito embora o tom de agressividade simbolize uma das marcas inerentes ao poema, sinalizando com isto os diferentes graus de violência assinalados por Javier Gasparri (2012) -, o título escolhido por Néstor Perlongher opera a partir de distintas inflexões, cuja principal remete-se ao fato de que "aquele que foge de sua mãe" é que sai exitoso em seu combate. O eu poético perlongheriano foge da mãe lezamesca, colapsando os significados e significantes do enunciado barroco, a fim de delirar a mãe freudiana, abrindo "[...] los cofres y diciendo: "Mamá/ tuve una polución en la que aparecías [...]" (PERLONGHER, 1997a, p. 48), em que era objeto do desejo, da insubordinação. Assim, "(Por un pasillo humedecido y hosco donde todo fulgor/ se desvanece) / Por esos tragaluces [...]" a voz poética importuna “[...] la yertez de los muertos, su/ molicie, yerras por las pirámides hurgando entre las/ grietas, como alguien que pudiera organizar los sismos" (Idem).

Confirma-se, deste modo, que, sim, é possível escrever poesia após a barbárie, embora afirme-se que: “[...] Ya no se puede disertar” (1997a, p. 355). Giovanne Rodrigues Jardim e Cristiéle Santos de Souza (2012) discorrendo sobre os princípios teóricos e metodológicos referentes às relações entre lírica e sociedade, apostam na máxima de que 
[...] não só a lírica é possível após Auschwitz, mas a vida biológica, a vida política, e todas as dimensões outrora ofuscadas pela máscara de um regime totalitário, por um período de incertezas e inseguranças, não qualitativamente diferentes do hoje, mas afastados por um tempo histórico necessário para poder-se olhar para o passado com certa distância, por meio de um afastamento imprescindível para perceber que o ser humano é capaz de muitos recomeços [...]. (JARDIM; SOUZA, 2012, p. 63).

Recomeços, por exemplo, como os que vemos em "Canción de amor para los nazis en Baviera" (1997a, p.26) quando "Marlene Dietrich/ cantaba en Londres una canción entre la guerra [...]", versos sobre os quais o eu poético deixa em relevo as arestas de uma totalidade permeada por inúmeras contradições, como ocorre em "Por qué seremos tan hermosas...": "Por qué [...]/ abriremos la puerta de calle/ al monstruo que mora en las esquinas. (1997a, p. 56). Em "Canción de amor para los nazis en Baviera”, muito embora o eu poético tenha consciência de que a violência opera como elemento estruturante da relação estabelecida com Nelson - outro personagem da trama, para quem dirige "una canción de amor":

Oh no no no es cierto que me quieras

Oh no no no es cierto que me quieras

Sólo quieres a tu padre, Nelson, que murió en Trafalgar

y ese amor es sospechoso, Nelson

porque tu papá

era nazi!

$[\ldots]$

Ay ay ay me dabas puntapiés [...]"

isto não o impede de experimentar cenas de entrega e desejo com seu verdugo:

[...]

y nos íbamos a hacer

el amor a mi buhardilla

[...]

estaba tu pistola de soldado de Rommel

ardiendo como arena en el desierto

un camello extenuado que llegaba al oasis 
de mi orto u ocaso o crepúsculo que me languidecía y yo sentía el movimiento de tu svástica en mis tripas oh oh oh oh. (Idem).

A possibilidade de pensar a poética perlongheriana, bem como a atenção que o poeta concede à memória, sobretudo se considerarmos os poemas de Austria-Hungría, são aspectos que simbolizam a possibilidade de repouso em nosso questionamento inicial: o poeta recorre à estética neobarrosa para escrever poesia após a barbárie: "Producto de certo despedazamiento del realismo, la eclosión de una variedad de escrituras 'instrumentales', más o menos transparentes, dispersa en el desierto los ajuares de los estilos cristalizados" (PERLONGHER, 1997b, p. 115). Por outro lado, tais elementos configuram-se como caixas de ressonância de vozes e imagens que colocam a escuta em estado de alerta, já que escrever poesia após a barbárie, especificamente a instaurada em contextos latino-americanos, converte-se num exercício que requer acionar distintos espaços, como os linguísticos, históricos, sociais e culturais. Aspecto que implica não apenas colocar estes territórios em estado de confluência e circularidade, como também insistir no processo de atualização da história, como forma de explorar novas possibilidades de interpretação do passado recente: 'El neobarroco [...] 'neobarroso' en su descenso a las márgenes del Plata [...] no funciona como una estructura unificada, como una escuela o disciplina estilística, sino que su juego [...] parece dirigido a montar la parodia, la carnavalización, la derrisión [...]" (PERLONGHER, 1997b, p. 115, grifos nossos).

Neste sentido, as instabilidades topográficas, genéricas e formais com que trabalha Néstor Perlongher confirmam que a estética neobarrosa não se monta sobre um "solo clássico", antes, evidencia a oscilação e uma série de movimentos migratórios. Os 
múltiplos fluxos constitutivos da estratégia de escrita apresentada por Néstor Perlongher estão orientados por um estilo performático, que aposta em processos criativos e fecundos. O material textual aparece, então, como organismo palpitante e de renovação estética, como sinalizou Nicolás Rosa (1996). Não só o desabamento de geografias instituídas, a fragmentação identitária e a rebeldia retórica protagonizam a conduta desterritorializante do escritor. Seu principal ponto de partida consiste em dinamitar a pretensa transparência do "real", tornando descontinuidade e dissimulação aspectos sumamente operativos. Néstor Perlongher inscreve a língua num campo de disputas e resistências, como bem assinalou na introdução a Caribe transplatino: poesia neobarroca, cubana e rioplatense (1991).

A instabilidade de seus textos radica no conceito de carnavalização: a máscara encobre o rosto, disfarça, dissimula. O enunciado é sempre heterogêneo e reflete uma cadeia rizomática de sentidos que, no lugar de valores absolutos, é compreendida como possibilidade, como aquilo que o enunciado pode evocar. Neste sentido, o neobarroso é interpretado como enunciado que corrói, desestabiliza e fragmenta os significados da língua, isto é, como estratégia que "[...] dissolve a pretensa unidirecionalidade do sentido em uma proliferação de alusões e toques, cujo excesso impõe seu esplendor altissonante [...]" (PERLONGHER, 1991, p. 17). O estilo assumido por Néstor Perlongher,

Não procede apenas a uma substituição de um significante por outro, e sim multiplica, como num jogo de duplos espelhos invertidos [...], os raios múltiplos de uma polifonia [...], desdobrando-os em sua rede associativa [...] de um modo rizomático, aparentemente desordenado, dissimétrico, turbulento [...] como se uma feira gitana irrompesse no alvoroço cinza da Bolsa". (Idem, pp. 17-18). 
A instabilidade, a ilusão dos sentidos, a torção da matéria e da forma revelam-se, portanto, como elementos que atacam o enunciado clássico, revelando, por outra parte, a obscuridade turbulenta e criativa dos escritores inscritos nesta estética e que mobilizam novos modos de se relacionar com a materialidade textual, sobretudo em tempos ou logo depois da barbárie. 


\title{
Capítulo II - Corporalidades em ruínas: os “cadáveres” da nação
}

\subsection{Perlongher, o aedo de thánatos; ou a morte como ordem fundadora}

\begin{abstract}
"Al cuerpo moribundo de una estética dominante se le inyecta una cepa perversa de sí mismo, una 'lepra creadora' que la exaspera y, tras llevarla a su límite, arroja como resultado un cuerpo nuevo, medio vivo y medio muerto, pero productivo".
\end{abstract}

(Ezequiel Zaidenwerg, 2015, p. 440).

Recuperando Walter Benjamin, Lourdes Kaminski Alves e Toani Reinehr (2014) assinalam que algumas personagens "[...] alcançam sua plenitude alegórica na morte, momento em que o espírito é liberado '[...] somente assim, como cadáveres, têm acesso à pátria $[\ldots] "$ " (p. 7). A vida, nesta perspectiva, é compreendida como uma espécie de argumento, segundo o qual se dá "produção do cadáver". Muito embora não seja pretensão deste trabalho explicar incisivamente os significados atribuídos à morte debate realizado exaustivamente por outras pesquisas -, destacamos que em "O grotesco e a construção alegórica em "Ensaio sobre a cegueira e As intermitências da morte, de José Saramago", Lourdes Kaminski Alves e Toani Reinehr acolhem a morte como uma espécie de libertação à qual: “[...] caberá representar os vícios, [...] as paixões. O disforme, o ridículo, o risível, o feio, o pérfido [...] numa palavra, o inverso, é por tais máscaras que o grotesco se manifestará, isto é, ele se transfigura em tudo o que é avesso [...] destoa da voz oficial" (Idem, p. 8). Para as autoras, o grotesco tende a operar como categoria que “[...] pode questionar o que se diz verdadeiro, desmascarar as virtudes, ampliar a significação [...]”, abrindo espaço para as "ideias proibidas" (Idem). As avaliações que classificam a morte como instância vinculada à construção de um mundo em ruínas perdem sua hegemonia. De acordo com João Pedro Rodrigues Santos: “[...] muitas 
sociedades antigas interpretavam a morte não como um fim, mas sim como o começo de uma nova existência e de uma certa plenitude" (2017, p. 23).

Nota-se, deste modo, o potencial da categoria apresentado em uma pluralidade de discursos, dentre os quais aqueles que evidenciam, de modo específico, o viés analítico e interpretativo que ilumina a prática literária. Em textos como "El cadáver", "El cadáver de la nación", "Cadáveres" e "Evita vive", por exemplo, Néstor Perlongher leva à exaustão a respectiva categoria, sobretudo porque - conforme sinaliza Ezequiel Zaidenwerg: "[...] hay en Perlongher una obsesión por los cadáveres [...] en el sentido que lo vivo y lo muerto entran en una zona de contigüidad [...]” (2015, p. 443). Um aspecto, no entanto, precisa ser esclarecido: o fato de que na escrita perlongheriana vida e morte simbolizam, antes, espaços análogos, cujos desdobramentos expõem um território corporal de onde se originam os processos de insubordinação pretendidos pelo escritor.

Para compreender o lugar que ocupa o corpo cadavérico na escrita perlongheriana torna-se necessário, porém, ter em vista o conceito de abjeção desenvolvido por Silvana Mandolessi, em Una literatura abyecta: Gombrowicz en la tradición argentina (2012). Interessa-nos de modo específico o caráter plural a partir do qual se forja o conceito, considerando neste trabalho uma das três possibilidades de definição que a autora apresenta: o de categoria política. Em primeiro lugar, vale destacar o fato de que, de acordo com Mandolessi, não podemos pensar em termos de uma "[...] definición unívoca de la abyección" (p.27), o que pode ser provado por meio da heterogeneidade de interpretações. Mais que definir o conceito, Silvana Mandolessi insiste numa espécie de cartografia da noção, analisando não somente a abjeção enquanto categoria política - 
conforme explorado contemporaneamente por Judith Butler -, como também considerando-a através das noções psicanalítica e estética.

Neste sentido, é de nosso interesse a leitura que a teoria cultural apresenta a respeito da abjeção enquanto categoria política, que: "Pertenece plenamente a las operaciones del poder simbólico que estructuran los límites de la identidad" (MANDOLESSI, 2012, p. 48); evidenciando, por outra parte, os mecanismos de funcionamento do poder social, que impõem “[...] su lógica a la subjetividad” (Idem, p. 44). Silvana Mandolessi revela que, enfatizando: “[...] su contenido político, lo abyecto es utilizado para criticar las relaciones de género y de clase'[...]" (2012, p. 29), de modo que “[...] la abyección es ante todo la dinámica de exclusión que regula al sujeto [...] imponiendo modelos [...] excluyendo [...], negando las posibilidades que se identifican con lo ambiguo, lo informe, lo que queda fuera de la regulación social” (MANDOLESSI, 2012, pp. 44 -45). A autora destaca, ainda, que: “[...] Ciertas situaciones u objetos tales como, por ejemplo, la contemplación del cadáver, provocan una reaparición de la abyección" (Idem, p. 35, grifos nossos).

Em "Cadáveres" - analisado anteriormente a partir do acento tonal que Néstor Perlongher imprime à leitura pública do poema -, identificam-se as construções que estetizam a ausência/presença da morte desde o ponto de vista político, sobretudo porque conforme entrevista concedida a Luis Chitarroni em 1988, Néstor Perlongher afirmava: ““Cadáveres' podría incluirse en un grupo de textos que dijeran algo sobre la guerra sucia [...]” (p. 24 apud ZAIDENWERG, 2015, p. 445). Segundo Javier Gasparri, existe uma “inmediatez imponente” em muitos poemas escritos por Néstor Perlongher, já que: “[...] aún haciendo una lectura distraída, ligera o impresionista de la poesía [...] salta a la vista 
que allí hay algo que es posible pensar vinculado a la política - sin caer por eso en generalidades [...]" (2012, pp. 17-18). Néstor Perlongher se contrapõe aos dispositivos do poder, principalmente porque contestou o regime de exceção que asfixiou a sociedade argentina, no final dos anos 70 e início da década seguinte.

Enquanto um dos mais emblemáticos textos da poética perlongheriana, “Cadáveres" expõe uma "mancha", um “corte”, distintas rupturas e insubordinações em relação à logica hegemônica. O poema instala sua lei:

[...] instala su lógica [...] presuntamente hermética, autónoma, pero al mismo tiempo requiere para ser leído de una serie de saberes culturales que están alojados en el interior del texto como pedacitos de su afuera, del exterior, y que dan lugar a la tensión hermetismo-referencialidad (GASPARRI, 2012, p. 24).

Por meio das mais de cinquenta estrofes que estruturam o poema e do estribilho "Hay Cadáveres" - repetido incessantemente diversas vezes -, Néstor Perlongher lança importantes considerações acerca do estado de exceção instaurado durante o último regime ditatorial argentino. Com relação ao conceito, Giorgio Agamben explicita que: “[...] o estado de exceção apresenta-se como a forma legal daquilo que não pode ter forma legal", determinando a desestabilização da lei, sobretudo porque sugere a existência de contravenções políticas que deslocam os códigos vigentes, provocando, assim, certa “[...] indeterminação entre democracia e absolutismo" (GREINER, 2010, pp. 12-13).

A partir da leitura que faz da obra do filósofo italiano, em $O$ corpo em crise: novas pistas e o curto-circuito das representações (2010), Christine Greiner aponta que: "O estado de emergência ou estado de exceção tornou-se a regra", revelando com isso tanto a anulação da ordem jurídica e constitucional, quanto a legitimação de poderes que 
impõem barreiras disciplinares; simbolizando, ainda, a fragilidade por que passa a democracia diante de medidas excepcionais.

Em "Cadáveres" o poeta designa tanto um traço de realidade, quanto demonstra que “[...] ficou difícil sustentar que a morte se tornou invisível ou proibida porque ela está o tempo inteiro acontecendo e parece mais do que nunca exposta" (VIRILIO apud GREINER, 2010, p. 32). "Cadáveres" inscreve-se, portanto, numa atmosfera profanadora, que expõe uma época de sombras e horrores, cujos desdobramentos pertencem a regimes extremamente exasperantes e perversos, sobretudo pelas zonas de indistinção que instauram. A zona de indistinção - que aqui entendemos ainda como espaço de contiguidade entre a vida e morte, entre a vida e a fabricação de "cadáveres"-, é um segmento altamente produtivo para o desenvolvimento desta análise, principalmente porque Néstor Perlongher propõe uma tessitura poética em que o leitor se percebe transitando por entre "abismos ainda não nomeados, como espécies de valas em que é depositado o estribilho: "Hay Cadáveres". Neste poema, especificamente, os "cadáveres" perlongherianos aparecem em decomposição, espalhados e em trânsito simbólico. Para o eu poético torna-se impossível proceder à captura destes corpos que também dinamitam a estrutura formal do poema. Cada estrofe não é outra coisa senão a tentativa de recompor a corporalidade do cadáver. Nesta poética, menos que sepultar, as trincheiras trazem à tona a crise produzida pelo terrorismo de Estado.

Em "Cadáveres" encontramos o "sopro do morto" que “(...) se torna 'a melodia que ressoa' e que vai misturar-se e diluir-se na 'massa das ondas, no trovão dos ruídos, no todo a respirar o sopro mundo"” e principalmente na escritura (NANCY, 2014, p.76). O eu poético explora o "sopro do morto", cuja ausência de materialidade física repercute 
na paisagem apresentada. Já na primeira estrofe, a cadência e a enumeração dos versos são rompidas pelo refrão. A estratégia reiterada ao longo do poema manifesta a quebra de uma harmonia dominante nos versos iniciais, contribuindo, desse modo, para a proliferação do abjeto, cujos "cadáveres" se arrastam ao longo da materialidade textual como a "[...] correíta de esa hebilla que se corre, sin querer, en el techo [...]". Para Pablo Gasparini: “'Hay Cadáveres’ transforma-se, com certeza, em um fator que decanta (no sentido daquilo que o poema não consegue assimilar" (2007, p. 170), principalmente devido à turbulência de vozes e o hermetismo inserido a partir de referências aparentemente desconexas acumuladas ao longo do texto.

Como núcleo do enunciado poético, a morte configura-se como produção em massa, cujos “cadáveres” aparecem: "Bajo las matas/ En los pajonales/ Sobre los puentes/ En los canales". Entre tetrassílabos e redondilhas menores, a melodia explicita prolongamentos sonoros significativos, sobretudo porque as aliterações construídas expressam o funcionamento de engrenagens. Por detrás da suposta paisagem, notamos o funcionamento de uma máquina ${ }^{23}$, como uma espécie de locomotiva que está: "En la trilla de un tren que nunca se detiene"; "tren" que, por um lado, explicita que a "morte" nunca cessa, seja literal ou simbolicamente e, por outro, parece encaminhar-nos rumos às trincheiras e depósitos destes cadáveres - que por seu turno operam como uma sucessão de cortes ao longo do poema ao mesmo tempo que deflagram aspectos inerentes à história coletiva. Embora estejamos tratando de uma poética do deslocamento, esta cena pode ser considerada como um referente por excelência, aproximando o leitor ao contexto de

\footnotetext{
${ }^{23}$ É importante notar que, aqui, a máquina não opera como sinônimo de avanço e progresso, conforme simbologia recorrente ao longo do século XX, muito ao contrário. Já que, por intermédio das analogias, podemos recuperar a máquina - não só na escrita deste autor, mas como veremos ao longo do respectivo século na produção de vários escritores -, funcionando por antonomásia em relação ao Estado de exceção.
} 
massacre e horror instaurado pelo estado de exceção, cujos desdobramentos predicam-na lato sensu como uma ordem fundadora.

Além disso, por meio da justaposição de cenas conferidas ao cotidiano repressor, dado o elemento político a que vincula suas reflexões, Néstor Perlongher confirma os excessos de sua poética, cujas imagens estabelecem e ampliam paisagens culturais, memórias textuais e linguísticas, que [...] marcarían la presencia fuerte de una escritura política, con un claro impulso de intervención [...] al mismo tiempo que una aspiración a nombrar, registrar, la violencia política [...]" (GASPARRI, 2012, p. 18). Em estudo sobre a obra de Néstor Perlongher, Gabriela Ferro (2010) ressalta:

Se NP privilegia o trabalho com a linguagem em sua produção poética, não deixa também de aliar aos seus poemas assuntos que o insiram no contexto de sua época, como os desdobramentos filosóficos e sociais dos movimentos contraculturais da segunda metade do século XX; assuntos que o liguem às discussões nacionais argentinas, como as polêmicas em torno da figura de Eva Perón ou com relação às consequências do fim da ditadura argentina, em 1983, que trouxe à tona os milhares de mortos vitimados pelas ações violentas empreendidas por esse governo". (2010, pp.11-12).

Verifica-se que nestas paisagens e memórias prevalece um "montar la parodia", que desritualiza e subverte a leitura canônica de determinados discursos. A gargalhada escandalosa do eu poético reincide contaminada não só por meio de inflexões como "Ay", "Uy", "Uau", etc; como também através de construções que "[...] sussurram vislumbres de histórias, mexericos, boatos ou, ainda, denúncias de bairro em que [...] se diz uma mesquinha moralidade pública" (GASPARINI, 2007, p. 169), recreando, deste modo, o tom prosaico constitutivo do enunciado poético perlongheriano.

Era: 'No le digas que lo viste conmigo porque capaz que se dan cuenta' 
O- 'No le vayas a contar que los vimos porque a ver si se lo toma a pecho'

Acaso: 'No te conviene que lo sepa porque te amputan una teta' Aún: 'Hoy asaltaron a una vaca'

'Cuando lo veas hace de cuenta que no te diste cuenta de nada ....y listo'

Hay Cadáveres

$[\ldots]$

Yo no te lo quería comentar, Fernando, pero esa vez que me mandaste a la oficina, a hacer los trámites, cuando yo cruzaba la calle, una viejita se cayó, por una biela, y los carruajes que pasaban, con esos crepés tan anticuados (ya preciso, te dije, de otro pantalón blanco), vos crees que se iban a detener, Fernando? Imaginá...

Hay Cadáveres

$[\ldots]$

Ay, no le digas nada a doña Marta, ella le cuenta al nieto que es colimba!

Y si se entera Misia Amalia, que tiene un novio federal!

Y la que paya, si callase!

La que bordona, arpona!

$\mathrm{Ni}$ a la vitrolera, que es botona!

$\mathrm{Ni}$ al lustrabotas, cachafaz!

$\mathrm{Ni}$ a la que hace el género 'volante'!

NI

Hay Cadáveres.

$[\ldots]$

- Todo esto no viene así nomás

-Por qué no?

- No me digas que los vas a contar

-No te parece?

—Cuándo te recibiste?

- Militaba?

—Hay Cadáveres? (1997a, pp. 111-123).

Evidenciando, por um lado, o trabalho polifônico da tessitura poética; por outro, constata-se nestes versos a agudeza do estilo perlongheriano: versos livres, conversações mescladas a uma espécie de "interrogatório" policial e denúncias de bairros, como assinala Pablo Gasparini (Idem), armam uma série de referências que, apesar do hermetismo, podem ser relacionadas ao contexto de exceção política. Muito embora a 
história apareça recreada por meio do tom prosaico de "Cadáveres" - aspecto que se confirma, principalmente, por meio da leitura pública que o poeta realiza, conforme discutido no capítulo anterior -, o poema expõe o inominável que se experimenta diante da morte.

Em “Cadáveres” a superabundância de corporalidades em ruínas argumenta, não em favor da perda do seu objeto: "Ya no se puede sostener: el mango/ de la pala que clava en la tierra su rosario de musgos/ el rosario/ de la cruz que empala en el muro de la tierra de una clava [...]" (Idem); isto é, os "cadáveres" enquanto corporalidade residual não se manifestam como entidades arbitrárias, simbolizando o que falta. Antes, refletem aquilo que excede, complementa e dilata o enunciado poético. Revela-se, com isto, o jogo estético produzido por Néstor Perlongher, já que o “[...] espaço barroco é o da superabundância e do desperdício [...] compraz no suplemento, na demasia [...] resíduo que poderíamos descrever como alteridade [...]", além do desequilíbrio, desarmonia e ruptura da homogeneidade (SARDUY, 1979, p. 77). Neste poema, Néstor Perlongher opera como o aedo de thánatos, que deprava e provoca o espessamento da história; a morte, como ordem fundadora, servindo como argumento para uma série de outros textos escritos pelo autor, como observado adiante.

\subsection{A antinaturalidade do cadáver de Eva Perón}

Na retomada e ampliação de determinadas imagens, Néstor Perlongher procede à antinaturalidade, sobretudo quando recobre a problemática da morte, interpretando-a não mais como um evento natural vinculado ao "valor inestimável da vida humana". O escritor opta por inserir na "ordem dos acontecimentos das "coisas naturais"” (CUNHA, 
2010, p. 186) uma nova lei, compreendida como antinatural e a partir da qual, por exemplo, o cadáver de Eva Perón é recapturado e ressemantizado. A antinaturalidade, neste sentido, pode ser relacionada ao inatural proposto por Susan Sontag (1964), que para a autora estaria relacionado ao "exagero" e "artifício".

A ideia de aniquilamento derivada da morte não revela uma escolha anunciada no projeto de escrita do autor. Datado em 1975, o polêmico conto "Evita vive"24 tripudia a sacralidade atribuída ao tema - aspecto que, em sentido amplo, atravessa a relação que o escritor instaura a partir de seus "cadáveres". Antes de evidenciar uma predileção do autor, o texto perlongheriano e os personagens que resgata tendem a convocar o espaço de alteridade inerente à morte ao mesmo tempo que ressignificam o processo de desintegração orgânica, entendido como “o fim da vida consciente da matéria do qual somos constituídos”, como enfatiza Anderson Santana Cunha (2010, p. 186). O corpo de Eva Perón, neste sentido, não é determinado pela lei que rege os eventos naturais, isto é, não é perpassado pela dissolução e consequente decomposição, sendo devorado pelos vermes que corroem irremediavelmente o corpo em estado de putrefação. Antes, esta corporalidade rearma e lança um novo olhar - sobre a finitude humana, obviamente -, mas principalmente sobre a história.

$\mathrm{Na}$ condição de cadáver, Eva Perón aparece em outros dois textos perlongherianos: "El cadáver", de Austria-Hungría (1980) e "El cadáver de nación”, de

\footnotetext{
${ }^{24}$ Escrito em 1975 e originalmente conhecido como "Evita Lives" (My deep dark pain is love - 1983), "Evita vive" foi publicado em Cerdos y Peces (abril, 1987) e El Porteño (abril, 1989), conforme assinalam Christian Ferrer \& Osvaldo Baigorria e Adrian Cangi - os quais selecionaram e republicaram o conto tanto em Prosa plebeya: ensayos (1997) quanto em Evita vive e outras prosas (2001).
} 
Hule $(1989)^{25}$. Com esta personagem, Néstor Perlongher manifesta “[...] o desmoronamento central do velho corpo e a promessa intensiva de um corpo por vir" (CANGI, 2001, p. 13). "El cadáver" e "El cadáver de la nación” simbolizam o lugar de contemplação enquanto espaço contraditório e ambivalente. O corpo de Eva Perón, de pele cancerosa e marcado por umas "manchitas en la cara", não é outra coisa senão o abjeto por excelência. A corporalidade do cadáver funciona como estratégia a partir da qual Néstor Perlongher “[...] parece se colocar do lado de um afrontoso antimonumento. Tocando o que por definição é intocável, a sua poesia converte [...] o sacro em abjeto, conversão que parece delimitar e dividir a ambiguidade inerente ao termo" (GASPARINI, 2008, p. 172).

Nestes poemas, os "sayales de la santa $[\ldots] /$ momi-/ficada o muesca $[\ldots]$ " são capturados pelo eu poético, que insiste em trabalhar com o "mito", "zombi escarlata" de "nariz quebrada", "kanekalon" e esmalte Revlon. Revelam-se os absurdos da narrativa oficial, pois como afirma o eu poético: “[...] la Diosa no/ se muere”. Lembremos, ainda, que - roubado - o corpo de Eva Perón só pode ser enterrado vinte anos depois. Além da comoção a que é elevada a protagonista, já que "la muchedumbre [...]" que "se agolpa en los pasillos" com "olor a orquídeas descompuestas" aparece contemplando "el cuerpo yacente/ de Eva" “[...] en la atmósfera cerrada y casi fría del boudoir artificial”, escuta o leitor: "Vamos, no juegues con ella, con su muerte/ déjame pasar, anda, no ves que ya está muerta!". Observa-se, desse modo, a ambivalência com a qual o eu poético dispersa a sacralidade do mito, já que o encerra numa atmosfera de "olor a flores viejas/ y perfumes chillones". O corpo convalescente de Eva Perón começa a ser confundido: "entre la

\footnotetext{
${ }^{25}$ Vale sublinhar, no entanto, que uma série de outras publicações entre relatos, peças de teatro e textos ficcionais que têm Eva Perón como protagonista ocorreram durante e após o final do século XX.
} 
multitud/ que emergía desde las bocas de los pasillos/ dando voces de pánico” (1997a, p.

43). O poeta sequestra e subverte a história impressa na narrativa oficial.

Muito embora "uma saga de mulheres" tenha atraído o olhar curioso do poeta, a obsessão por Eva Perón foi predominante, como sublinha Adrian Cangi (2001).

Uma saga de mulheres atraíram o olhar do poeta: a branca Camila O'Gorman, que se "deixa enredar por esa baba"; Mme. S., "adornada de galhos, de gladíolos"; Dolly, "a coxa, a que trepa com Deus?"; Marta, a linda mulheridade "vesga nos labirintos da maquilagem"; Chola, a jóia de araque com toques de incrustrações de uma alça; Ethel, "enlameada pela sede de um mendigo"; Daisy, sob o escangalhamento desses saltos nas escadinhas"; Amelia, "a noiva que viu o noivo cair com o freio ensanguentado, a glande"; Delfina, a que "fumava/lenço no pescoço"; e as proliferantes Tias [...]. Entre essas mulheres das margens reinou Eva Perón, a deusa soberana que levou o poeta aos extremos da fascinação. Ela exerce uma atração particular que a transforma em jóia da poesia e do conto rioplatense, arrastando-a do altar aos limites do arrabalde [...] a história é recuperada como ruína, imprimindo, na caducidade alegórica de um rosto-cadáver, a representação do erotismo e da morte. [...] o corpo imolado de Eva é a figura da alma coletiva [...]. (CANGI, 2001, pp. 14-15).

Nos textos que enfatizam a imagem fúnebre de Eva Perón, a corporalidade recupera o abjeto, inserindo-a em ordens que modificam a lógica hegemônica. $\mathrm{O}$ corpo de Eva Perón aparece, portanto, “[...] sustraído a las leyes de la decadencia y la muerte [...]", corpo "impuro, frágil, sucio, sexual, mortal. (MANDOLESSI, 2012, p. 57). Para Nicolás Rosa (1997, p.55): "El cadáver como resto-rastro mortal convoca la eyección propia de las materias impuras, es lo abyecto por definición, materia obscena en espera de la disolución, la putrefacción" - o que, entretanto, não parece ser o destino deste cadáver.

O poeta recusa o princípio de morte atribuído ao cadáver histórico, propondo com isto uma espécie de devir Evita, que coloca lado a lado ficção e realidade. Como no relato histórico - ocasião em que o corpo de Eva Perón é embalsamado pelo espanhol Pedro 
Ara -, o cadáver resiste como nos conjuros de zumbificação expostos em Hule. Para Fernanda Vitorino Martins (2013): “Uma forma de recusa da morte é o recurso à técnica do embalsamento" (p. 10). Em "El cadáver de la nación”, Néstor Perlongher evidencia o trabalho de eternização do cadáver de Eva Perón realizado pelo anatomista espanhol Pedro Ara, sugerindo, inclusive, que o médico seria uma espécie de bokor, isto é, um tipo de sacerdote que dirige o ritual do vudu haitiano.

\begin{abstract}
Ara había cautelosamente rociado con el gas de la inmovilidad la yacencia del cuerpo en esa veinteañera eternidad celeste desde el cielo contempla oh impotente los esbirros pasándole en la ñata [...] avinagrado banlon con membrete de la Fundación y el bokor vestes negras alaridos como hélices los brazos agitando en la noche del pasillo las colas de las bolas de las minas que lloran en la noche el atajo partido de su muerte imperial [...] quiero que me dejen a solas con su muerte y en el laboratorio sustituir su sangre cancerosa por horchata de orquídeas amazónicas y brujerías incorporadas al hechizo de los pómulos aunque ella desee sonreír desde lo alto donde se ve yacer en el estuche como una joya [...]. (PERLONGHER, 1997a, p. 180).
\end{abstract}

Reatualizando o discurso histórico por meio de questões que vão desde a necrofilia ao périplo do cadáver: "[...] el cuerpo yacente/ de Eva, hurtado luego,/ depositado en Punta del Estel o en Italia/ o en el seno del río [...]" (PERLONGHER, 1997a, p. 43, grifos nossos) -, Néstor Perlongher contraria a máxima de que a “decomposição é o sinal do fracasso do homem" conforme assinalado por Philippe Ariès (2003, p. 58 apud MARTINS, 2013, p. 9). Especialmente em “El cadáver de la nación”, a construção formal apresentada reinsere a voz do cadáver, anteriormente anunciado em seu féretro. Divido em quatro partes enumeradas de 1 a 4, neste poema Néstor Perlongher expõe uma suposta conversação entre o cadáver e Pedro Ara, ocasião em que Eva Perón dá “orientações” que devem ser seguidas no momento de sua morte: "En cuanto me muera, quiteme el rojo de las uñas/ y déjemelas con brillo natural" (PERLONGHER, 1997a, p. 183). Transcrevemos, ainda, a terceira parte do poema, onde através do estilo prosaico o eu 
poético enfatiza detalhes aos quais se deve proceder ao se tocar na carne "casi necrosada" de Eva Perón (Idem, p. 182):

3.

Aranda ${ }^{26}$ hágame los rulos con la delicadeza de una onda cetrina nívea en su rubor amar el illo el bigudí sujéteme con un papelito disimulado en la tintura de la entretela para erguir el mamotreto del rodete hasta una altura suficiente para espantar las engrupidas junto a mi lecho [...] Aranda hágame los rulos no me lo deje entrar al puto de la cabeza contra el piso al que se arrastra como un saurio al que inclina la sien [...] frente al primer moreno de la guardia téngame en guardia contra él que mis muchachos son sensibles que no se enteren que ha tocado mis carnes casi necrosadas con esos dedos que han hurgado braguetas en el Rosemarie o en la penumbra del Eclaire [...] Aranda hágame los rulos y disimule las hebillas entre los tropos del cabelo para que a quien las encuentre se eles disuelvan el las yemas.

$[\ldots]$

Y así despidióse el peluquero. (PERLONGHER, 1997a, p. 182).

O que significa, então, esta corporalidade que refuta a ordem da finitude humana?

O leitor sabe que Eva Perón não poder morrer - ao menos não simbolicamente. Eva Perón, isto é, o devir Evita, assinala a possibilidade de vida do próprio poeta: "Enigmático e mascarado, o poeta é ora Rosa Luxemburgo, ora Rosa L. de Grossman...” (CANGI, 2010, p. 11) e por que não Eva Perón? A alteridade do cadáver deste personagem estabelece vínculos polissêmicos com o devir mulher do escritor, o qual sempre procurou se instalar "no plano de ruptura do gênero" (Idem). Identificar-se com o cadáver embalsamado de

\footnotetext{
${ }^{26}$ No ritual de preparação do cadáver, inicialmente exposto em velório ao longo de 16 dias e sobre o qual o anatomista espanhol trabalharia durante anos, alguns assistentes de Pedro Ara garantiram que penteado, unhas e vestimentas da morta estivessem em perfeito estado. Neste poema, especificamente, é intrigante o fato de Néstor Perlongher mencionar como interlocutor do cadáver o personagem Aranda, estabelecendo com isso analogia tanto com o nome do próprio médico quanto com o major Arandia, que foi cúmplice do sequestro do corpo embalsamado de Eva Perón. Na história oficial, Arandia manteve o cadáver no porão de sua residência. Aos poucos, o interesse pelo cadáver transformou-se em uma macabra obsessão. Numa noite, ouvindo barulhos ao redor de sua casa, o major atira pensando estar sob ameaça de peronistas interessados em roubar o cadáver. Arandia, entretanto, dispara e assassina sua própria mulher, na época grávida de 6 meses.
} 
Eva Perón reflete de certo modo o desejo de Néstor Perlongher de confrontar “os regimes de propriedade e de identificação" (CANGI, 2001, p. 12).

Como em "Cadáveres", os textos desta saga operam como metonímia dos corpos imolados pelo estado de exceção. Abjeção e impureza se convertem, desse modo, em mecanismos que reestruturam não só a relação com a alteridade da morte como também sinalizam uma escrita permeada por oscilações e importantes movimentos de confronto com aspectos identitários. Neste sentido: "Uma ética da crueldade e o prazer na ironia definem, em Perlongher, uma política de estilo que absorve e transforma a violência do mundo". (CANGI, 2001, p. 19)

\subsection{O cadáver da nação: entre o sagrado e o êxtase}

Além do aspecto fantasmal que instaura nos poemas anteriormente mencionados, em "Evita vive" Néstor Perlongher comete um verdadeiro atentado à sacralidade predominante nos setores populares peronistas, os quais concebiam Eva Perón como Santa Evita, rainha de coque loiro e mãe dos descamisados. Neste conto, a estratégia paródica aparece vinculada à problemática da política sexual, a partir da qual o desejo consome o tom sagrado atribuído à figura histórica, expressando assim o gesto profano e dispersivo provocado pelo escritor. Em nota ao texto, lemos: "Los peronistas usaron la consigna 'Evita vive', con diferentes aditamentos: 'Evita vive en las manifestaciones populares', 'Evita vive en las villas', 'Evita vive en cada hotel organizado', etc. A nota de rodapé escrita por Néstor Perlongher deixa em relevo a imortalidade em que estava inscrito o mito peronista. 
Néstor Perlongher afirma que em "Evita vive" existe uma tentativa de fazer com que os textos "brinquem" em torno a literariedade dos enunciados, “[...] haciendo aparecer a Evita 'viviendo' situaciones conflictivas y marginales”. De acordo com Pablo Gasparini, "Evita vive" “[...] nos dice que la Victoria de Eva es Volver a Vivir, un volver a vivir que en la reconfiguración montonera de la figura de Eva, será un vivir político" (2016, pp. 164-165). Como os demais textos constitutivos desta saga - cadavérica -, "Evita vive" "[...] arma un sistema de referencias históricas [...] un escenario bélico, esto es, una realidad que es un campo de batallas" (GASPARRI, 2012, p. 30).

Subdividido em três cenas justapostas, "Evita vive", "que [...] puede ser considerado un auténtico cuento maldito de la historia de la literatura argentina"27, ademais da onisciência narrativa, revela ao leitor a transgressão por meio da qual Eva Perón ressurge e vuelve para falar com seus "descamisados": "Grasitas, grasitas míos, Evita lo vigila todo, Evita va a volver por este barrio y por todos los barrios para que no les hagan nada a sus descamisados" (Idem, pp. 193-194, grifos nossos). O aparecimento da protagonista insinua uma espécie de ressurreição em contraponto análogo à ordem cristã, principalmente porque “[...] vigila todo [...]" e sabe o que acontece com seus herdeiros. Evita é uma bochinchera. Seu volver a ver ${ }^{28}$ - já que "Evita vino desde el cielo" (Perlongher, 1997a, p.193)" -, estabelece que

\footnotetext{
${ }^{27}$ De responsabilidade dos editores, esta nota aparece no conto "Evita vive", figurando tanto em Prosa plebeya: ensayos, publicada em 1997, cuja seleção e prólogo são de Christian Ferrer e Osvaldo Baigorria; quanto em Evita vive e outras prosas, publicada em 2001 pela Iluminaras, com seleção e prólogo de Adrian Cangi e tradução de Josely Vianna Baptista.

${ }^{28}$ É interessante recuperar esta afirmação em seu sentido mais amplo, já que "volver a ver" vincula-se de modo intrínseco ao texto em questão revelando que aspectos sensoriais, sobretudo aqueles ligados à visão, são explorados por Perlongher de maneira quase exaustiva. Haja vista à reincidência com que verbos que designam a ação de "ver" e "olhar" configuram a materialidade textual, tais como: "mirarla", "mirada", "mirándome", "no la había visto", "dónde la vi la primera vez" e quando, não diretamente, são insinuados de modo indireto, como no caso do enunciado já apresentado: "Evita lo vigila todo", entre outros. Notemos
} 
Evita regresa. No para ser montonera (una combatiente guerrillera que lucha por el socialismo) sino que vuelve para ser, entre las millones de posibilidades de su retorno, una prostituta, una drogadicta, una reventada. Es que la Evita de Perlongher, al decir de Martín Kohan y Paola Cortes, es una "Evita-década-del-'70, camisa y pelo suelto, que expresa en su cuerpo el puro goce" 29 .

Observa-se, neste sentido, a constituição de uma nova ordem do corpo sagrado da Evita peronista: "Evita vuelve, sí, pero para ser puro sexo, droga y descontrol” (Cf. nota 27). Conforme assinala Mariano Pacheco (2012), a figura de Eva Perón assume distintas simbologias, sendo tanto "la Señora", "la Primera Dama" e a Eva "combativa", reivindicada pelo discurso militante; quanto "el puro goce corporal”. Evita regressa e é ressignificada ${ }^{30}$, para ser drogada, puta e fazer de seu corpo espaço de experimentação e ambivalência. Sobretudo porque, como sublinha Mariano Pacheco (Idem):

En Evita Vive, la diversión, el goce, la fiesta, el juego y la aventura lograrán construir una realidad muy diferente a la histórico-social y sus representaciones, tanto peronistas como antiperonistas. A través de una mirada lúcida, Perlongher plantea una importante batalla contra todos aquellos que libran "cruzadas morales", se erigen en censores y que suelen ser los que pretenden instituirse en jueces, en quienes definen lo que está bien y lo que está mal.

Se por um lado em "Evita vive" abrimos a porta de uma "pieza" que possui "un olor a muerta", por outro, en "un estuche" encontramos la joya, um collar-preciosidades,

que o paradigma da visão, enquanto experiência exercida pelo olhar, configura-se de modo duplamente contemplativo: não só a contemplação daquilo que é o cadáver e que representa o abjeto neste texto, como também dar-se conta de que se é observado por este Outro.

29 PACHECO, Mariano. "Bañando en ácido a Eva Perón”. Texto disponível em: http://www.pagina12.com.ar/diario/suplementos/soy/subnotas/2715-263-2012-11-27.html. Acesso em novembro de 2016.

30 Tendo em vista "[...] el peso ideológico de la perenne figura de Eva Perón en la memoria colectiva y en el embate político de la República Argentina", como assinala Pablo Fernando Gasparini em seu artigo "Las vueltas de Evita (reescrituras políticas en Walsh, Perlongher y Cucurto)", publicado na Revista Landa (2016). 
alfiler del estilo, só possíveis neste tipo de escrita com "fuerte impronta simbólica" e participação na constituição do imaginário social. Como assinala Osvaldo Baigorria $(2016)^{31}$ :

[...] el mito de Eva era arrojado a los márgenes, arrastrado por el Bajo para terminar de nuevo elevado, ya no como santa sino como mujer pública y diosa lumpen de las minorías. Una imantación blasfema, aunque no precisamente gorila, que descolocaba el relato militante tradicional.

Néstor Perlongher apropria-se do corpo de Eva Perón, e por meio de sua sintaxe dessacraliza o mito. Em "Evita vive" o contista opera por oposição ao sagrado: se “veneración" num primeiro momento, ocasião em que o corpo é visto desde a perspectiva da "relíquia", passamos ao campo oposto a esta instância, que por si só “[...] ritualiza y congela” (ROSA, 1997, p. 46). Néstor Perlongher sequestra Evita Perón do lugar sagrado, fazendo deste corpo uma escansão às avessas, visto que “[...] descubre que la significación [...] está reglada por la abyección del cuerpo en una trasmutación alquímica [...]" (ROSA, 1997, pp. 50-51).

Instaurado a partir dos excedentes do corpo, "Evita vive" evidencia o oximoro neobarroso por excelência. Sem compreender muito bem o que se passa no discurso deste autor, o leitor se percebe, então, “[...] agarrando de las mechas” (PERLONGHER, 1997a, p. 191), num exercício intelectual exangue. Se não prosa plebeya, poderíamos incluir este texto no catálogo de prosas profanas da literatura latino-americana, já que Néstor

31 BAIGORRIA, Osvaldo. "Retrato maldito con una Evita zumbi". Disponível em: http://www.revistaenie.clarin.com/literatura/Retrato_maldito_con_una_Evita_zombi_0_1576642331.html Acesso em agosto de 2016. 
Perlongher esgota o aspecto monumental de seu objeto: sua personagem - cadáver aparece sensualíssima e mergulhada em profana eroticidade:

[...] rapidito me volví para la pieza, abro... y me la encuentro a ella, con el negro. Claro, en el primer momento me indigné [...], pero el negro dulcísimo me dirigió una mirada toda sensual y me dijo algo así como: "Veníte que para vos también alcanza". Bueno, en realidad, no mentía, con el negro era yo la que abandonaba por cansancio, pero en el primer momento, qué sé yo, los celos, el hogar, la cosa que le dije: "Bueno, está bien, pero ésta ¿quién es?”. El negro se mordió un labio porque vio que yo había entrado en la sofocación, y a mí, en esa época, cuando me venía una rabieta era terrible [...]. Ella me contestó, mirándome a los ojos (hasta ese momento tenía la cabeza metida entre las piernas del morocho y, claro, estaba en la penumbra, no la había visto): “¿Cómo? ¿No me conocés? Soy Evita”. (PERLONGHER, 1997a, pp. 191-192, grifos nossos).

Analogamente, o escritor confere à protagonista da narrativa um êxtase profundo. Evita fica “[...] entre las piernas [...]" del negro (PERLONGHER, 1997a, p. 192), já que “[...] era una puta ladina [...]”, que “[...] chupaba como los dioses" (p. 194).

Em sentido amplo, menos que sustentar o decoro impresso em determinados discursos - vinculados a estatutos políticos e sociais específicos -, os textos que integram esta saga ressignificam os sentidos atribuídos à morte. Nestes textos, o poeta opta por jogar entre a decomposição e a recusa da morte, isto é, entre a desintegração orgânica e o embalsamento de um corpo que tripudia a lei natural. Nesta recusa encontra-se a voz de Perlongher, cuja estratégia recompõe e mantém "viva" a voz marginal do cadáver. Diferentemente do significado conferido ao embalsamento oficial - de certo modo vinculado aos pressupostos da religião, que insistem numa espécie de recusa da morte por meio da eternização do cadáver -, o poeta trabalha com a perspectiva da alteridade. 
Por um lado, a corporalidade exposta em "Cadáveres", "El cadáver” e "El cadáver de la nación" convoca a voz do poeta, que os formaliza na tessitura poética. Por outro, em "Evita vive" o cadáver da nação opera metonimicamente, revelando com isso os corpos imolados de "Cadáveres". O corpo de Eva Perón não é outra coisa senão a tentativa de atribuir sentido às mortes, sequestros e desaparecimentos de uma infinidade de cadáveres que não chegaram a compor as estatísticas. Embora escrito alguns anos antes da publicação de "Cadáveres", "El cadáver" e "El cadáver de la nación", "Evita vive" conserva uma força política extremamente simbólica. Em sentido estrito, este conto aparece como argumento que articula as demais corporalidades trabalhadas por Néstor Perlongher, tais como a desejante e a extática - analisadas nos capítulos três e quatro, respectivamente. A partir do conto "Evita vive" Néstor Perlongher revela os descalabros de uma história suturada pela necrofilia e périplo do "cadáver da nação". O mito aparece como puro sexo, gozo, descontrole e experimentação: “[...] había que drogarse porque se era muy infeliz", diz a protagonista (Idem, p. 194). Violência, desejo e êxtase inscrevemse nesta cartografia corporal: a Evita perlongheriana de pelos sueltos e uñas largas pintadas de verde é tanto a possibilidade de contravenção e combate à hegemonia da lei, quanto um gesto incômodo, a mescla ruinosa, decadente e abjeta.

Conclui-se que nesta saga Néstor Perlongher ganha o aval de seus "cadáveres", sobretudo o de Evita Perón. Neste sentido, a boca do morto beija a mão do poeta, fazendo escarrar de sua pena a tradução de um tempo de sombras, horrores e ausências advindos de uma geografia degradante; que, por outro lado, expõe o gesto irônico e sarcástico ante a história e os discursos hegemônicos. 


\section{Capítulo III - "Nas barras da lei": corporalidades clausuradas e ameaça ao desejo homossexual}

\subsection{A ameaça ao desejo}

Na crítica à modernidade desenvolvida por Michel Foucault $(1984,1988)-$ fortemente influenciada pela genealogia nietzschiana -, e a partir da qual são discutidos tanto os fenômenos sociais quanto as relações de força (do saber-poder) na esfera política (ASMANN; NUNES, 2007, p. 17) é que Néstor Perlongher problematiza importantes questões, contrapondo-as às explicações universalizantes que sustentam “[...] a possibilidade de 'respostas inabaláveis' ou de uma 'saída definitiva"” para as problemáticas, “[...] que dizem respeito ao conjunto social em toda sua complexidade política" (Idem, p. 3). Entende-se que a leitura proposta pelo antropólogo, especialmente em sua dissertação $O$ negócio do michê - prostituição viril (1987a), no artigo O que é AIDS (1987b) e nos ensaios de Prosa plebeya: ensayos (1997) distancia-se da tentativa enclausurante oposta ao campo relacional, sobretudo porque suas investigações discutem onde, quando e em quais condições constitui-se a experiência. Para Néstor Perlongher: “[...] o "exercício da liberdade" estaria muito mais presente na crítica às identidades instituídas historicamente, do que em uma suposta promessa de 'libertação dos sujeitos' por alguma ciência ou projeto 'emancipador"” (ASMANN; NUNES, 2007, p.5) - o que, no entanto, não impede a viabilização de formas alternativas de constituição das liberdades individuais.

A leitura que Néstor Perlongher realiza de autores como Michel Foucault antecipa uma série de debates levados a cabo a partir dos anos 80, como no caso da obra Problemas de gênero: feminismo e subversão da identidade, cuja autora, a filósofa pós-estruturalista 
Judith Butler, discorda de várias etapas da tese de Julia Kristeva, quando esta se coloca “[...] em favor do semiótico como fonte de subversão efetiva” (2003, p.122). A contrapartida de Judith Butler defende que a tese proposta por Julia Kristeva é não só contraditória, posto que se apropria de forma acrítica da teoria da pulsão lacaniana, como também - ao tentar subverter "Lei Paterna" - acaba reproduzindo o sistema conceitual hegemônico. Mesmo que defenda que a linguagem poética funciona como território de subversão, Julia Kristeva “[...] admite que o semiótico é invariavelmente subordinado ao Simbólico [...]", já que fala em termos de uma ordem anterior à cultura, isto é, uma ordem pré-discursiva em que o corpo materno figura como "portador de um conjunto de significados anteriores à própria cultura" (2003, p.123) - aspecto que, por outro lado, revela que a recusa plena à cultura paternalmente sancionada torna-se absolutamente impossível. Enfatiza Judith Butler: "Por meio disso, ela preserva a noção de cultura como estrutura paterna e delimita a maternidade como uma realidade essencialmente précultural" (2003, p. 123). Julia Kristeva não consegue desenvolver o "projeto emancipador" e subversivo a que se propõe, fracassando em sua empreitada, tanto em decorrência de que “[...] postula e nega alternadamente o semiótico como ideal emancipatório" (2003, p. 122), quanto porque “[...] reinstala a lei paterna [...]” (2003, p. 123) que tenta subverter.

Recuperando Michel Foucault, Judith Butler expõe que: “O corpo só ganha significado no discurso no contexto das relações de poder. A sexualidade é uma organização historicamente específica do poder, do discurso, dos corpos e da afetividade" (BUTLER, 2003, p. 137). Atribui-se significado à dinâmica social, portanto, no contexto das relações de poder. Sobre esta questão Néstor Perlongher expõe que: 
El niño al nacer está sometido a la presión de una determinada serie de pautas morales que le son impuestas de antemano. Y que no son casuales. Están en relación con el sistema social al que pertenecen. Así aprende el niño un determinado modelo de relaciones sociales, que son las que tiene su família, donde se da fundamentalmente el poder del padre [...]. Así el hijo de obrero va a ser educado, desde la familia y luego desde la escuela, que le corresponde ser obrero y el hijo de familia bien será educado desde la cuna y por los sistemas educativos para mandar. (1997b, p. 244).

No excerto, Néstor Perlongher trata de uma questão que não só diz respeito à luta de classes, confirmando, deste modo, a existência de um sistema capitalista hegemônico produtor de desigualdades sociais, como também deixa em evidência as múltiplas facetas constitutivas deste projeto - como ocorre por exemplo em "La batalla homosexual en Argentina" $(1973)^{32}$, reportagem realizada pelo semanário argentino Así, de grande circulação na época. Neste documento, os entrevistados explicitam que no interior das relações sociais determinadas pautas, sobretudo morais, impostas pelo sistema hegemônico de dominação: “[...] no se tolera la homosexualidad en tanto significa una violación de esos papeles" (1997b, p. 244). “A una sociedad de dominación como la nuestra esos papeles son indispensables" (Idem), ratificam os militantes da Frente de Liberación Homosexual Argentina (FLH).

Os membros da extinta FLH especificam que tanto o corpo quanto a liberdade experimentada pelas formas de insubmissão do desejo constituem-se como alvos de enquadramento e repressão, como forma de assegurar o poder institucionalizado. Por outra parte, a premissa perlongheriana opera como modo de subversão efetiva - já que, assim como assinalado por Michel Foucault, o mecanismo de repressão é interpretado

\footnotetext{
${ }^{32}$ Christian Ferrer e Osvaldo Biagorria apontam que na reportagem são transcritas somente as falas de três membros da Frente de Liberação Homossexual (FLH): Néstor (23 anos), Fuad (30) e Manuel (33) - os dois primeiros estudantes de Sociologia e Arquitetura, respectivamente; e o terceiro professor do curso de Ciências Sociais. Vale mencionar, ainda, que esta foi uma das primeiras apariçõos públicas de Néstor Perlongher.
} 
tanto como força proibidora quanto generativa: ao publicar textos como "El sexo de las locas", "Matan a un marica", "La desaparición de la homosexualidad" bem como a dramática crônica “A prisão de Antônio Chrysóstomo”, Néstor Perlongher, de dentro da lógica dominante, abala o discurso institucionalizado, até mesmo porque considera “[...] microterritorialidades que demarcan grados de ruptura con el orden" (CANGI, 2000a, p. 69).

No prólogo à Prosa plebeya: ensayos (1980-1992), Christian Ferrer e Osvaldo Baigorria (1997, p. 9) afirmam que para Néstor Perlongher: “[...] el deseo no asumía una figura sólida, homo u heterossexual, sino que se impulsaba como fuerza que hace estallar las clasificaciones con las cuales la normatividad imperante, familiarista y capitalista, basaba su estrategia de control social [...] (Idem). Os críticos destacam que:

La calle albergó su oficio de militante político de izquierda, su participación pionera en la organización de los primeros grupos gay argentinos (el F.L.H, activo entre 1971 y 1976) y al fin su investigación artesanal de las prácticas sexuales que se cumplen en las zonas rosas de toda ciudad y su involucramiento exploratorio en las experiencias rituales propias de una religión brasileña emergente. En esos recodos y curvas, rastrearíamos en vano una fisura entre el liberacionismo homosexual de los comienzos y la posterior crítica lapidaria de Perlongher a la "identidad gay". Nos perderíamos en la búsqueda de grietas. El deseo - y no "lo gay" - fue el punto de anclaje de Perlongher para pensar lo político, en una época en que se proclamaba abiertamente que "todo lo personal es político", pero en la cual los homosexuales "no existían". Una vez en una charla entre militantes de izquierda alguien quiso ser sarcástico en su comentario respecto a un chico [...]: "pero ¿ese es un hombre, una mujer, o qué?" Parece que Perlongher habría respondido: "Es qué" [...]. Argentina, solía decir Néstor, es un paraíso policial en el cual la única sexualidad posible es triste o impostada, cuando no sórdida" (1997b, pp. 8-9).

Podemos dizer, inclusive, que a "contravenção à decência pública" funcionou como uma espécie de estratégia utilizada por Néstor Perlongher com o objetivo de contestar a ordem estabelecida, a repressão bem como a perseguição aos homossexuais, cuja acolhida se 
deu, sobretudo, durante a última ditadura militar argentina. Assinala o ensaísta em "Nena, llévate un saquito":

Nena, si querés salvarte, nunca te olvides el saquito, el largo Chanel, el rodete. No te quedes dando vueltas en la puerta de un bar. Y lo peor de lo peor, no se te ocurra hablar por la calle con alguien de quien no sepas su nombre, apellido, dirección, color de pelo de la madre [...]: la policía los separa y si no saben todo uno del otro, zas, adentro [...]. Y nunca te olvides lo que decía el General: "de la casa al trabajo y del trabajo a la casa". (1997b, p. 27).

Nota-se que a reflexão ressalta o paroxismo a que são elevadas as categorias de ironia e sarcasmo às quais recorre o ensaísta, já que Néstor Perlongher tinha clareza quanto à existência de uma estrutura moral e jurídica operando em defesa do sistema. Ainda na reportagem apresentada pelo semanário, os militantes afirmam: "[...] la raíz última de la persecución al homosexual es política; se da porque la libertad sexual no le conviene a la clase dirigente y a la sociedad autoritaria. Y para ello recurre a todas las pautas tradicionales de moral" (1997b, p. 244).

\subsection{A prisão de Antônio Chrysóstomo ${ }^{33}$ : $O$ julgamento de um preconceito}

"O homem precisa de esperança para sobreviver" (Antônio Chrysóstomo, 1983, p. 93).

Lapa. Rio de Janeiro. Fim de 1979. Uma das mais dramáticas confabulações impede de ver as categorias de identidade como construções produzidas por instituições,

\footnotetext{
${ }^{33}$ Nos referimos à crônica "A prisão de Antônio Chrysóstomo", compilada em Evita vive e outras prosas (2001), obra organizada e prologada por Adrian Cangi e publicada pelo selo editorial Iluminuras.
} 
práticas e discursos, cuja origem é sempre múltipla e difusa (BUTLER, 2003). Revela-se a existência de uma perversa rede de controle exercido sobre a sexualidade, o desejo, os homossexuais e o corpo. Como assinala Judith Butler, tais categorias supõem uma formação específica do poder. "O preconceito, ao contrário do amor e da dobrada à moda do Porto [...]”, afirma Herbert Daniel (1983, p. 9), “[...] serve-se frio. Gelado. Mas confeitado e caulculista". Como assinalado em "Chave de cadeia”, Antônio Chrysóstomo foi, na realidade, uma espécie de bode expiatório capturado por uma "[...] malha de angústias, maledicências e enfadonhas perversões [...]”, foi um bode expiatório vítima das acusações e do “[...] poder do imaginário colonizado", produtor de ficções que, como expõe Herbert Daniel, aniquilam toda solidariedade possível (Idem).

O caso de Roosevelt Antônio Chrysóstomo de Oliveira, mais conhecido como Caso Chrysóstomo, teve grande repercussão no início dos anos 80. O qual não só atingiu o jornalista citado - quem passou 1 ano, 9 meses e 14 dias encarcerado -, como também deixou em pavorosa as homossexualidades amplamente atacadas no interior de um contexto asfixiante, cuja sociedade - comprometida exclusivamente com o julgamento de um preconceito - submetia o prazer "[...] às regras de qualquer catecismo" (1983, p. 14).

Néstor Perlongher analisa os autos do processo e escreve a crônica "A prisão de Antônio Chrysóstomo", subdividida em três partes: na primeira, "Montagem", o escritor recolhe os argumentos constitutivos da trama: descreve e analisa os mecanismos desde os quais se articula a intriga, bem como os aspectos inerentes aos discursos psicológicos e jurídicos; na segunda, "Fábula", apresenta a leitura do caso a partir da perspectiva da confabulação, entendendo os autos do processo como uma rede de referências, alusões e 
ramificações interpretativas oriundas dos delírios de seus enunciadores; por fim, na terceira parte, "Colofón”, o cronista conclui apresentando algumas considerações.

Do ponto de vista da forma, vale destacar o modo intrigante a partir do qual Néstor Perlongher arma o texto, contrastando uma série de procedimentos que, menos que evidenciar ipsis litteris a fidelidade ao gênero, colocam em pauta uma materialidade híbrida, que opera na intersecção entre a crônica e o ensaio. Em sentido estrito, em "A prisão de Antônio Chrysóstomo", Néstor Perlongher tem como ponto de partida um trabalho de base: comenta aspectos "reais", respeitando a ordem cronológica dos acontecimentos. Inclusive, após a última parte da crônica inclui: "Histórico do 'Caso Chrysóstomo"”, texto em que explicita datas e detalhes dos autos do processo por que passou o protagonista.

Diferentemente dos aspectos históricos e jornalísticos predominantes enquanto estratégias de escrita do gênero, em "A prisão de Antônio Chrysóstomo" a dimensão apresentada pelo cronista subverte a estrutura canônica. Néstor Perlongher insere divisões, subdivisões e questionamentos retóricos que não só favorecem a digressão textual, eliminando, assim, a concisão a que pertence o gênero; como também colocam em destaque as modalizações assumidas pelo cronista. A inserção de notas, observações e questionamentos ironiza a "maquinária da inquisição" (CANGI, 2011, p. 18), que motivou a perseguição ao protagonista da trama.

Neste enredo, o protagonista Antônio Chrysóstomo, figura de considerável influência nos meios artístico e jornalístico da época, adota Cláudia Pinheiro Santiago - 
na época com aproxidamente três anos de idade -, em fevereiro de 1979. Até então, Cláudia Pinheiro Santiago vivia com a mãe, Maria Pinheiro Santana, nas ruas da Lapa, no Rio de Janeiro. Quase sempre eram vistas na porta do prédio onde funcionava a redação do jornal Lampião e trabalhava Antônio Chrysóstomo. Solidarizado com a situação de emergência em que se encontrava a menor, o jornalista decide dar entrada no processo de adoção, contrariando, assim, os conselhos de amigos próximos. Aguinaldo Silva, autor de "Chrysóstomo: qual o crime?"34, comenta que os amigos tentaram dissuadir Antônio Chrysóstimo quem, no entanto, insiste e “[...] consegue a tutela legal da pequena [...]" (PERLONGHER, 2001, p. 61).

Aproximadamente um ano e meio após a adoção, Chrysóstomo torna-se vítima de uma microoperação de política sexual, cujas denúncias articuladas por uma série de personagens - vizinhas do prédio; empregadas domésticas; um michê que fora seu companheiro; um colega da bancada conservadora do Movimento Brasileiro de Liberação Homossexual, João Antônio Mascarenhas; uma psicóloga e um médico psiquiatra -, e isentas de quaisquer "vestígios de violência"35 sobre a menina, resultam no pedido de prisão preventiva do jornalista. Como no caso de João Antônio Mascarenhas, que pretendeu construir uma visão acusatória do protagonista, por meio de carta a Darcy Penteado, a acusação do personagem é capturada e ironizada na incisiva do autor:

A história que levaria Antônio Chrysóstomo à prisão parece começar por uma compaixão. Tudo começa quando Chrysóstomo se compadece da filha da mendiga Maria Pinheiro Santana, que vivia - literalmente na porta do Lampião. Aguinaldo Silva conta que os amigos tentam

\footnotetext{
${ }^{34}$ SILVA, Aguinaldo. "Chrysóstomo: qual o crime? In.: Careta, n. 5, 4 de agosto de 1981, pp. 56-59.

${ }^{35}$ Após solicitação, o exame de corpo de delito é realizado pelos médicos legistas do Instituto Afrânio Peixoto, os quais emitem o seguinte laudo: "[...] não constam sinal de violação do hímen da menina" (PERLONGHER, 2001, p. 81).
} 
dissuadi-lo; mas Chrysóstomo insiste e consegue a tutela legal da pequena mendiga de 3 anos. É essa menina que João Antônio Mascarenhas vê em sua visita à casa de Chrysóstomo: "Nessa ocasião (abril de 79), ao chegar ao apartamento de Chrysóstomo, deparei-me com uma menininha imunda, só de calcinhas, que, no primeiro momento, imaginei que fosse filha de uma empregada doméstica muito relaxada. Tal era a sujeira da criaturinha que eu, que gosto de crianças (para brincar com elas, não para atos libidinosos), mas de crianças limpas, não me animei nem a falar, nem a fazer-lhe um agrado" [...]. Deixando de lado as preferências lúdicas de Mascarenhas (cabe perguntar se ele esperava encontrar a menina, tirada há dois meses da rua, vestida segundo a moda das instituições inglesas), já vemos perfilar-se aí um elemento moral (a sujeira) e um dos personagens do drama (a empregada doméstica). (PERLONGHER, 2011, pp. 61-62, grifos nossos).

De início essencialmente descritiva, a terceira parte da crônica provoca uma importante torção da narrativa, sobretudo porque Néstor Perlongher emite seu posicionamento, ocupando o lugar que legitimou sua voz insubmissa. Em "A prisão de Antônio Chrysóstomo", cuja essência é suberveter o padrão imposto pela lei do gênero - no duplo sentido do termo -, o cronista observa o réu e trabalha em sua defesa, já que de acordo com sua conclusão: “[...] a Justiça urdiu uma fábula paranoica, pela qual fantasmas suspeitos circulam [...] o escarnecimento de Chrysóstomo parece constituir um microcampo experimental, que visa $[\ldots]$ dar um basta intimidatório àqueles que ultrapassaram [...] os limites da censura (PERLONGHER, 2011, pp. 74-77).

Chrysóstomo perde a custódia de Cláudia, que é levada para as dependências da Fundação Nacional do Bem-Estar do Menor (FUNABEM) (DANIEL, 1983; CHRYSÓSTOMO, 1983; TREVISAN, 2000; PERLONGHER, 2001). Vale mencionar que, dentre as várias narrativas produzidas em torno ao caso, duas ganham destaque: a de Ana Alves de Souza e Maria Aparecida Batista, ambas vizinhas do acusado:

b. Ana Alves de Souza, também vizinha, formula a acusação: às vezes, Chrysóstomo deixava a menina com ela, chegando a brigar com ele fisicamente a respeito de sua "educação"; primeiro diz ter visto a 
menina com a "vagina avermelhada". Depois (audiência de 20/7/81) se desmente; chorando: "não se lembra de ter referido que viu os órgãos genitais de C. inchados e vermelhos"; nem "de ter Maria Aparecida lhe falado sobre o aparelho genital da criança no banho"; que "sua vizinha tem lhe pressionado para falar mal do acusado".

[...]

d. Maria Aparecida Batista, também vizinha, disse ter visto a menina com a vagina inflamada. Que a menina repetia "Homem Mexe": ela interpretou: - e acreditaram nela - que Chrysóstomo metia seus dedos na vagina da filha [...]. (PERLONGHER, 2011, pp. 64-65).

Em 3 de julho daquele mesmo ano, Antônio Chrysóstomo tem sua prisão decretada. Lê-se nos autos do processo, anexado em obra póstuma escrita pelo próprio jornalista:

O DENUNCIADO, segundo se dessume ao inquérito policial realizado, tem várias espécies de vícios e, certamente, algumas taras. Alcoólatra e homossexual, o DENUNCIADO foi retirar da sarjeta uma menor, sob o pretexto de que a queria para si para efeito de criação. Considera o Promotor: "Ora, um homem solteiro que leva uma menina para um ambiente onde impera a perversão sexual (vivia no mesmo apartamento com outros três homens de sexualidade pelo menos duvidosa), já é coisa estranha". E conclui: "Tem-se, em consequência, que o DENUNCIADO é pedofílico [...]". (CHRYSÓSTOMO, 1983, p. 15).

Após 8 meses de prisão preventiva, isto é, em 12 de fevereiro de 1982, Antônio

Chrysóstomo é: "Levado a julgamento, [...] condenado a 2 anos e 8 meses de reclusão e

2 meses e 20 dias de detenção, além da medida de segurança pelo prazo de um ano"

(CHRYSÓSTOMO, 1983, p. 16, grifos nossos) ${ }^{36}$. Néstor Perlongher ressalta: "Nesse

\footnotetext{
36 Sem aprofundarmos a questão, o trabalho de João Silvério Trevisan, Devassos no Paraíso: A homossexualidade no Brasil, da colônia à atualidade, publicado em 1986, apresenta importantes contribuições, sobretudo porque, ao trabalhar de modo comparativo com os casos de Febrônio Índio do Brasil e Antônio Chrysóstomo, o crítico não somente evidencia as relações existentes entre os dois casos, apesar da distância temporal que os separa; como mostra que "[...] diante da homossexualidade, o sistema psiquiátrico pouco mudou, sendo coadjuvado por novos e mais sutis sistemas de opressão" (2000, p. 195). Choca o caso de Febrônio Índio do Brasil quem, em 1982, com 86 anos de idade, recebeu a visita de Peter Fry no Manicômio Judiciário, onde permanecia internado desde 1927. Segundo o antropólogo, Febrônio foi um dos mais velhos prisioneiros e o que ficou encarcerado por mais tempo no Brasil, tendo vivido em total reclusão por 57 anos, sem "[...] nunca ter sido sentenciado pelos crimes que alegadamente teria
} 
grito comum, progressistas e conservadores parecem se unir", dando força e suporte à “[...] confabulação de vizinhas, criadas e michês [...]” (PERLONGHER, 2011, p. 66), isto é, uma “[...] fábula - edípica - é montada no caminho para o diagnóstico” (Idem, p. 68): Chrysóstomo, enfatiza Néstor Perlongher, se converteria na bicha estupradora e na bicha que maltrata crianças: "matam-se vários fantasmas de um só tiro" (Idem, grifos nossos).

O "Caso Chrysóstomo" representaria uma espécie de ritual de expiação, cujo bode expiatório é o homossexual "mal-comportado". Para A. Silva, "a temporada que se abria com a perseguição movida contra Chrysóstomo era de caça aos diferentes, rapaziada do estigma, em cuja primeira linha confessadamente formamos" (refere-se ao pessoal de Lampião)...

A apresentação de um exemplar de Lampião como prova da imoralidade do acusado indica a hipótese de um conluio contra os doentes e perversos: "O que se quer é esmagar Antônio Chrysóstomo [...] para fazer o mundo desabar em cima dele. Tanto que o promotor anexou ao processo, como uma das provas contra o réu, um exemplar do jornal Lampião, dizendo que basta olhar suas manchetes para saber que são pervertidos tantos os que editam como os que lêem" (Aguinaldo) - responsabilizando, assim, tanto editores como leitores, por um estupro que "nem mesmo ocorreu" (PERLONGHER, 2011, p. 73 , grifos nossos).

Nota-se, desse modo, que no caso Chrysóstomo pesou o julgamento de um preconceito - dada a situação e precariedade das provas: “[...] a sentença se acha baseada em conjecturas ou em referências isoladas e fugidias ... sem qualquer precisão [...]" (Documento 15, Poder Judiciário, Ap. 9.832 apud CHRYSÓSTOMO, 1983, p. 87). Como bem assinala Néstor Perlongher: “[...] como, no 'Caso Chrysóstomo', as barras da justiça, da intriga, da psicologia clausuram o corpo de uma bicha pública [...]” (2001, p. 80).

cometido, condenavam-no, vagamente, como um "louco moral", conforme assinalado por João Silvério Trevisan (Idem). [João Silvério Trevisan, assim como Antônio Chrysóstomo, trabalhou na edição do jornal Lampião: publicação dedicada à causa homossexual, e divulgada mensalmente entre os anos de 1978 e 1981]. 
Mesmo tendo seu "pedaço de vida" sequestrado injustamente, Antônio Chrysóstomo encerra seu testemunho dizendo: "O homem precisa de esperança para sobreviver" (CHRYSÓSTOMO, 1983, p. 93). Afinal, a que tipo de esperança se referia Chrysóstomo, quem esteve no cárcere durante quase dois anos, mesmo sem qualquer fundamento legal? A que tipo de esperança se referia quando "[...] a eventualidade de algum senso de humor [...]" há muito havia desaparecido (Idem)? A que esperança se referia quando a vida, assinalada pela tragédia, havia assumido um "[...] peso esmagador... que marca o encarcerado pela vida que lhe resta viver" (Idem, p. 94)? Enfim, a que esperança se referia? A única certeza, contudo, é a de que o caso Chrysóstomo assume o lugar de muitos Antônios e Febrônios, revalidando o lugar daqueles que, cotidianamente, assistem ao extermínio de seus sonhos, projetos e até mesmo da própria vida, sendo portanto uma voz de onde ecoa "o desespero dos oprimidos" (Idem, p. 96). Neste sentido, litígio, oposição e tensão caracterizam os argumentos desta história.

\subsection{O curto-circuito das relações: biopolítica e insubmissão}

“...es preciso vencer [...]. Sacar la cana de la cama, al ojo policial del cuarto ..."

(Néstor Perlongher, 1997b, p. 33).

Em “Néstor Perlongher. Por una política sexual” (2015), Javier Gasparri assinala a investida "escandalosa" de Néstor Perlongher: "[...] arrebatarle la hegemonía que ostentan "la moral y las buenas costumbres" sobre la sexualidad, en complicidad con el Estado que las codifica y regula [...] En este contexto, decir política tiene sentidos 
precisos: liberación, revolución” (2015, p. 3). O crítico observa que o exercício indigitado por Néstor Perlongher também pode ser assinalado como um gesto que aprofunda as críticas aos discursos de controle da vida e às forças de instrumentação legal, que elegem o biopoder como forma de controle e dominação do desejo: "Pues es del cuerpo que, al final [...] se trata (PERLONGHER, 1997b, p. 140).

[...] Foucault descreve as transformações da sociedade europeia do final do século XVIII, a partir do que ele chama de uma "sociedade soberana" para uma "sociedade disciplinadora", o que vê como o deslocamento de uma forma de poder que decide e ritualiza a morte para uma nova forma de poder que planeja tecnicamente a vida em termos de população, saúde e interesse nacional. Biopouvoir (biopoder) é o termo como se refere a essa nova forma de poder produtivo, difuso e em expansão. (PRECIADO, 2018, p. 1) 37. $^{37}$

Neste sentido, o biopoder se constitui como uma combinatória complexa de poderes, dentre os quais o saber médico e o poder policial. Estes, por seu turno, operam no sentido de "governar a vida": “[...] uma tecnologia política geral transformada em arquiteturas disciplinadoras (prisões, quartéis, escolas, hospitais, etc.) [...]”, que tendem aos processos de normalização, conforme assinala Paul Preciado (2018, p. 1). Roberto Espósito afirma que "[...] en el totalitarismo quien maneja, quien comprime, y a veces, quien suprime la

37 Paul B. Preciado (2018) estabelece um importante panorama acerca dos modos de produção de subjetivação. Não desconsidera, por um lado, o fato de Michel Foucault ter negligenciado "profundas transformações das teconologias de produção do corpo e da subjetividade", que foram se instituindo de modo paulatino com o avanço da II Guerra Mundial. Por outro lado, Preciado retoma uma terceira dimensão, ou sistema, de saber-poder, que para ele não é nem soberano nem disciplinar, não é pré-moderno nem moderno. Recuperando os filósofos franceses Gilles Deleuze e Félix Guattari, no epílogo de Mil Platôs especificamente, Paul B. Preciado (2018) explicita um novo "monstro" como forma de organização da sociedade, isto é, "[...] um subproduto do controle biopolítico" (p. 6): a sociedade de controle. "Esses três regimes de produção de corpos e subjetividades sexuais não deveriam ser entendidos como meros períodos históricos. O regime disciplinar não apaga as técnicas de soberania necropolítica. Da mesma forma, o regime farmacopornográfico não oblitera totalmente as técnicas biopolíticas disciplinares. Três técnicas diferentes e conflitantes de regime de poder estão justapostas e atuam no corpo produzindo nosso sujeito contemporâneo e nossa ficção somática" (Idem, p. 7). 
vida es el Estado [...]” (2009, p. 136), de modo que o homem não aparece como “[...] el dueño absoluto de su propio cuerpo" (Idem).

No ensaio "Nena, lleváte un saquito", que inaugura a seção "Deseo y Política”, de Prosa plebeya: ensayos, Néstor Perlongher inicia a discussão com duas importantes epígrafes: uma em que retoma Oliverio Girondo e outra por meio da qual recupera trechos do "Reglamento Policial de Contravenciones, inc. $2^{\circ} \mathrm{E}$ (1946)", em que lemos respectivamente:

i. $\quad \mathrm{Al}$ atardecer, todas ellas cuelgan sus pechos sin madurar del ramaje de hierro de los balcones, para que sus vestidos se empurpuren al sentirlas desnudas y de noche, a remolque de sus mamás - empavesadas como fragatas - van a pasearse por la plaza, para que los hombres les eyaculen palabras al oído, y sus pezones fosforescentes se enciendan y se apaguen como luciérnagas".

ii. Los que se exhibieren en comercios, plazas $\mathrm{u}$ otros lugares de esparcimiento público, con vestimentas indecorosas, o se despojaren en los mismos sitios de ropas de vestir, exigibles a la cultura social (...) serán reprimidos con multa o arresto. (apud PERLONGHER, 1997b, p. 25).

Além de retomar as exigências de que se cumpram os éditos policiais, como este de 1946, o escritor questiona com ironia: “¿En qué se basa la autoridá para saber cuándo una vestimenta es o no indecorosa?” (Idem), ¿dónde está el goce? ¿Qué pasa con la homosexualidad [...] en la Argentina, para que actos tan inocuos como el roce de una lengua en un glande, en un esfíncter, sea capaz de suscitar tanta movilización [...]?” Especificamente, a constituição de dispositivos, tais como o policial, o social e o familiar, que sem reconhecer os homossexuais "verdugueaban" e perseguiam a homossexualidade. ¿De dónde viene esa infatigable preocupación por los culos? 
Las locas [...] tenemos de qué quejarnos. Ahora el horror del genocidio - producto, también de la normalidad militar: hay fotos de Hitler acariciando niñas - ha develado la pesadilla de secuestros y desapariciones, de lo que no se hablaba antes. Sin embargo, allá por el 69 (bajo Onganía), haciendo mis primeros trabajos de campo, un muchacho muy bien vestido me invitó a subir a un auto. Accedo, allí hay otros dos que se acarician para mostrarme que son "entendidos". Resultado: tres horas de pánico y pálida. Despojada de mis bienes, una puta me dio dinero para volver al centro. Bajo del tren (había ido a parar a Olivos), y me para la cana. ¿La sospecha?: homosexualidad.

Hablar de homosexualidad en la Argentina no es sólo hablar de goce sino también de terror. Esos secuestros, torturas, robos, prisiones, escarnios, bochornos, que los sujetos tenidos por "homosexuales", padecen tradicionalmente en la Argentina - donde agredir putos es un deporte popular - anteceden [...] el genocidio de la dictadura. (1997b, p. 30).

De acordo com Gilles Deleuze e Félix Guattari, uma [...] importante tarefa desse trabalho disciplinador consiste em extrair o ânus dos circuitos de produção e prazer [...] “o ânus foi o primeiro órgão privatizado [...] serviu como modelo de toda privatização posterior, ao mesmo tempo em que o dinheiro veio para expressar o novo estado de abstração de fluxos" (apud PRECIADO, 2018, p. 3).

Retomando algumas das discussões presentes no $\mathrm{V}$ capítulo ${ }^{38}$ de Conversações, Gilles Deleuze apresenta o desenho de uma sociedade refém de fatores dissociativos ativados por distintos mecanismos de controle da vida. O filósofo fala em termos de mutação do capitalismo e como ponto de partida recorre ao debate foucaultiano acerca das sociedades disciplinares ${ }^{39}$-, as quais foram compreendidas como espaços de

\footnotetext{
38 "Post-scriptum sobre as sociedades de controle" (DELEUZE, 1992, pp. 219-226), texto publicado originalmente em L'Autre jornal, $\mathrm{n}^{\circ}$ 1, maio de 1990.

${ }^{39}$ Modelo sucedeu outro tipo de sociedade, isto é, a soberana. Gilles Deleuze aponta que a análise dos processos de mutação do capitalismo e consequentemente as sucessões entre um modelo de sociedade e outro (o que não deve ser entendido como simples evolução tecnológica), podem ser refletidas na maquinária utilizada no interior de cada processo. Por exemplo: numa sociedade - simples - como a "Soberana" destacam-se máquinas de manipulação também simples, tais como alavancas, roldanas, relógios; ao passo que nas "Disciplinares" observa-se a potência das fábricas com suas máquinas energéticas e os riscos de entropia e sabotagem. Por fim, nos "Controlatos" podem ser mencionados os
} 
organização dos grandes meios disciplinares ou de confinamento, tais como a família, a caserna, a fábrica, o hospital e a prisão - considerada como meio de confinamento por excelência: "[...] la vida debe, ante todo, mantenerse como tal, debe protegerse de la disolución que la amenaza [...]” (ESPÓSITO, 2006, p. 92).

Antes da crise experimentada por todo tipo de confinamento ${ }^{40}$ observou-se um capitalismo “[...] de concentração, para a produção, e de propriedade” (DELEUZE, 1992, p. 223), em que o capitalista - protagonista - exerce não só o domínio do “[...] projeto ideal dos meios de confinamento visível especialmente na fábrica: concentrar, distribuir no espaço; ordenar no tempo, compor no espaço-tempo uma força produtiva [...]" (Idem, p. 219), como também, sendo proprietário de "outros espaços concebidos por analogia", tem o controle da "[...] casa familiar do operário, [d] a escola" (Idem, p. 223, grifos nossos). Muito embora, como afirma Roberto Espósito ${ }^{41}$ :

El agotamiento progresivo de las categorías políticas modernas no significa su definitiva desaparición; por ejemplo, hasta el día de hoy sigue existiendo un Estado, sigue existiendo una soberanía [...] se abre en su interior una grieta, una herida de la cual surge progresivamente otra cosa [...]. Nadie ha imaginado que de un día para otro un régimen político termine y comience otro. Más bien se forman nudos, se abren problemas, se plantean cuestiones que ya no son posibles responder con las mismas categorías. (2009, p. 134).

papéis que cumprem tanto a Informática e os Computadores, quanto as interferências, a pirataria e os vírus que circulam nestes meios.

40 Já que, como assinala Gilles Deleuze, o próprio Michel Foucault reconhecia a brevidade destes modos de organização dos grandes meios de confinamento, tendo em vista o processo de sucessão por que passou.

${ }^{41}$ Em entrevista concedida a Vanessa Lemm e Miguel Vatter, na ocasião de sua visita a Santiago do Chile, em outubro de 2008. 
Sabemos que este modelo de sociedade sofreria importantes impactos no decorrer do século $\mathrm{XX}^{42}$ : “[...] a fábrica cede lugar à empresa. A família, a escola, o exército, a fábrica não são mais espaços analógicos distintos que convergem para um proprietário, Estado ou potência privadas, mas são agora figuras cifradas, deformáveis e transformáveis de uma mesma empresa [...]” (Idem, p. 224). Cessam os ruídos das fábricas entoando a violência provocada pelo silêncio dos escritórios: "Informam-nos que as empresas têm uma alma o que é terrivelmente a notícia mais terrificante do mundo”. Se antes os mecanismos disciplinares operavam por meio da radicalidade diante de grupos como a família, a escola, a fábrica, a prisão, etc., atualmente os processos de "adaptação" destes mecanismos encontram-se codificados através dos novos formatos e agenciamentos seja dos regimes das prisões e escolas, seja dos regimes dos hospitais e empresas. Sobre estes aspectos, Gilles Deleuze assinala:

No regime das prisões: a busca de penas "substitutivas", ao menos para a pequena delinquência, e a utilização de coleiras eletrônicas que obrigam o condenado a ficar em casa em certas horas. No regime das escolas: as formas de controle contínuo, avaliação contínua, e a ação da formação permanente sobre a escola, o abandono correspondente de qualquer pesquisa na Universidade, a introdução da "empresa" em todos os níveis de escolaridade. No regime dos hospitais: a nova medicina "sem médico nem doente", que resgata doentes potenciais e sujeitos a risco, o que de modo algum demonstra um progresso em direção à individuação, como se diz, mas substitui o corpo individual ou numérico pela cifra de uma matéria "dividual" a ser controlada. No regime da empresa: as novas maneiras de tratar o dinheiro, os produtos e os homens, que já não passam pela antiga forma-fábrica. São exemplos frágeis, mas que permitiriam compreender melhor o que se entende por crise das instituições, isto é, a implantação progressiva e dispersa de um novo regime de dominação. (DELEUZE, 1992, p. 225).

De acordo com Adrián Cangi (2000a, p. 46), o modo com que Néstor Perlongher propõe política evidencia um “enemigo molar”, localizado nas hastes de um capitalismo mordaz,

\footnotetext{
${ }^{42}$ Sobretudo após o período que compreendeu a II Guerra Mundial.
} 
bem como em seus modos de dominação; “"Molecularmente' se trata de no quedar inmovilizado por la máquina trituradora generadora de violencias”.

Por outra parte, a forma como interpreta e critica os processos de normalização da homossexualidade não se restringe tão somente aos setores marcadamente conservadores da sociedade, já que no esquema argumentativo de seu ensaio, Néstor Perlongher demonstra a ilimitada busca por modelos de conduta, por parte de grupos sociais minoritários, os quais se consideram marginalizados mas que, no entanto, manifestam discursos caracterizados pelas modalizações da normalidade clássica. De um lado: "Decía una diputada feminista brasileña, Ruth Escobar, en su campaña: "Que las mujeres puedan vivir su femeneidad, los negros su negritud, los homosexuales su deseo" (p. 33). De outro, além da afamada consigna levantada pela Juventud Peronista ${ }^{43}$, "Dice Carlos Franqui que en la Cuba castrista la lucha no era revolucionarios vs. contrarrevolucionarios, eran machos contra maricones" (pp. 30-31). Néstor Perlongher propõe pensar tanto a homo quanto a heterossexualidade antes como devires, que como marcas identitárias - aquele visivelmente considerado como aspecto extraordinário, já que imperavam distintas formas de governo das subjetividades:

O sexo se tornou parte tão importante dos planos de poder que o discurso sobre a masculinidade e a feminilidade e as técnicas de normatização das identidades sexuais transformaram-se em agentes de controle e padronização da vida. Em 1868, as identidades hetero e homossexual foram inventadas em uma esfera de empirismo, classificação taxonômica e psicopatologia. Da mesma forma, KraftEbing cria uma enciclopédia das sexualidades normais e perversas em que identidades sexuais se tornam objetos de conhecimento, vigilância e repressão jurídica. (PRECIADO, 2018, p. 2).

43 "No somos putos, no somos faloperos [...]". 
Para o poeta e ensaísta as mutações, consideradas como alternativas ao modelo castrador e que permitiam "[...] soltar todas las sexualidades: el gay, la loca, el chongo, el travesti, el taxiboy, la señora, el tío, etc [...]" (Idem), apontavam não somente a não submissão das singularidades a padrões genéricos como também, e principalmente: “[...] una fuga de la normalidad [...]", ou seja, "[...] sacar la cana de la cama [...], e das medidas profiláticas de imunização da vida, enfim, emancipar-se “[...] de la moral dominante [...]" (p. 50). Foi contra todas estas dimensões estruturantes do poder às quais se opôs Néstor Perlongher. Como explicita Jorge Panesi (2013) nunca antes, na história, “[...] las locas [...] pudieron hablar así en la poesía”. Néstor Perlongher - este agent provocateur ${ }^{44}$ inaugura ${ }^{45}$ o espaço discursivo e político que "[...] los grupos necesitan para hablar de sí mismos y establecer sus poéticas [...]” (Idem, grifos nossos). Em seus textos Néstor Perlongher nos devolve um aspiral de imagens permeado por uma multiplicidade de corpos. "El poeta entrega su cuerpo revelando los síntomas de la ciudad”. Para ele “[...] el cuerpo es un don [...]", "El cuerpo es una sustancia fundida con la ciudad" (CANGI, 2000a, pp. 119-120).

\subsection{Um longo ensaio sobre o desejo: $O$ negócio do michê}

Retomando a questão da violação às pautas morais constitutivas dos sistemas hegemônicos, conforme exposto no início deste capítulo, em $O$ negócio do michê: $a$ prostituição viril (1987), Néstor Perlongher insere um novo dado: inscreve-se como uma

\footnotetext{
${ }^{44}$ Em alusão à expressão utilizada por Christian Ferrer e Osvaldo Biagorria (1997), no prólogo a Prosa plebeya: ensayos (1980-1992).

45 Pois como assinala Javier Gasparri, em "Perlongher en la trinchera: sexualidad y afección" (s/d): "Perlongher trabaja con la suma de saberes actuales de sus años, pero también contiene en potencia lo que vendrá".
} 
espécie de reafirmação da condição marginal em que é posta o homossexual, tal como no caso Chrysóstomo - agora, no entanto, outros personagens aparecem como protagonistas. Neste longo ensaio sobre o desejo, Néstor Perlongher explora a figura do michê de rua enquanto "modalidade particular da prostituição virill, isto é, “[...] aquele que vende seus encantos em pontos: esquinas, bares de livre acesso, fliperamas, ruas [...]" (PERLONGHER, 1987a, p. 31). O antropólogo restringe seu espaço de observação, concentrando-se em determinados pontos da cidade de São Paulo: região do Ipiranga, São Luís, Marquês de Itu e Largo do Arouche.

Embora certo nomadismo configure o trottoir dos michês de rua - os quais não têm o hábito de “[...] se restringir a um único ponto, antes percorrem espaços fluidos, de onde se torna possível "[...] perambular de um local para outro [...]” revelando, com isto, os movimentos reais das redes relacionais (1987a, p. 32) -, com este desenho Néstor Perlongher estabelece uma possível cartografia que parece "[...] funcionar como o grande coletor das diferentes formas e gêneros da prostituição viril [...] (Idem). 


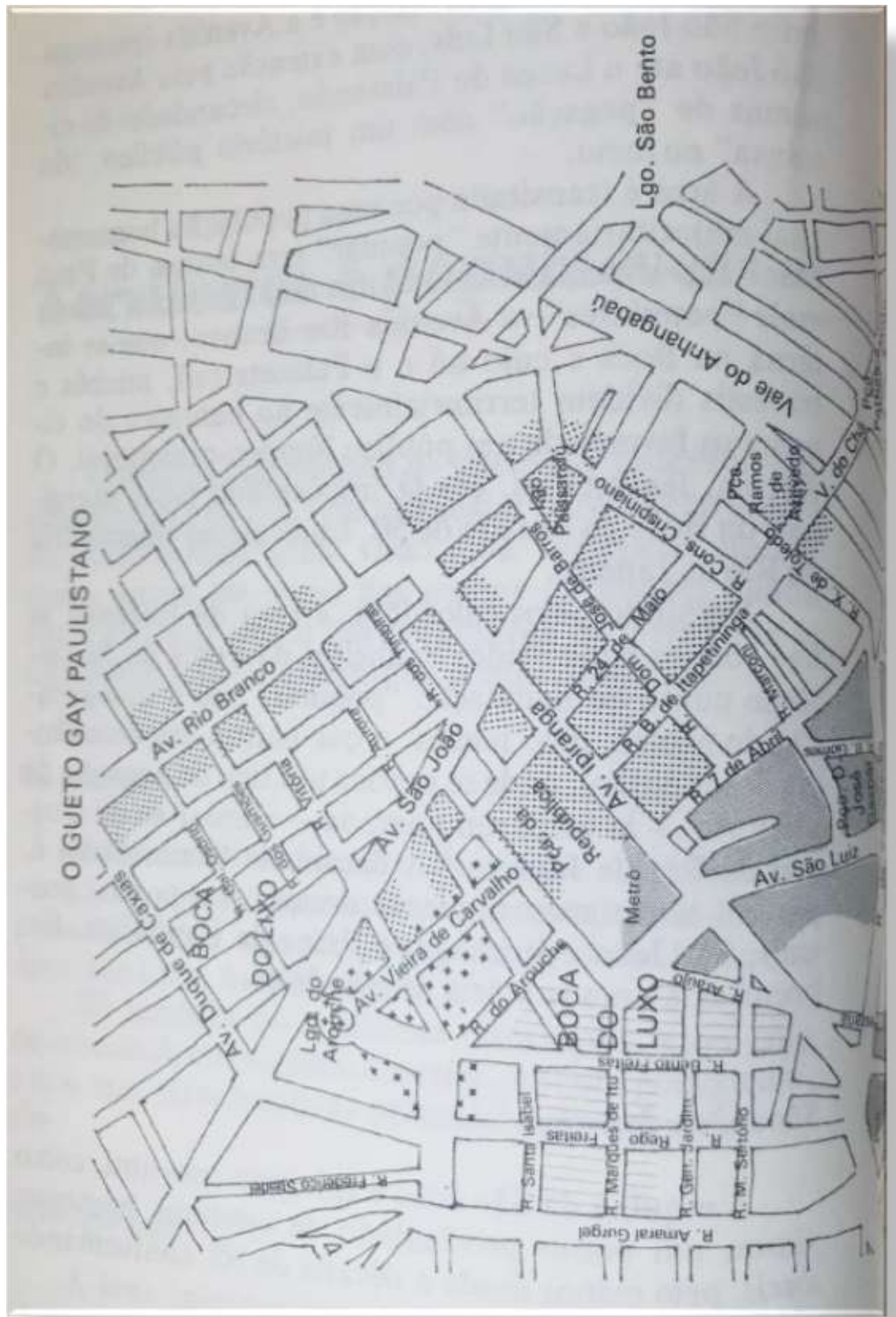




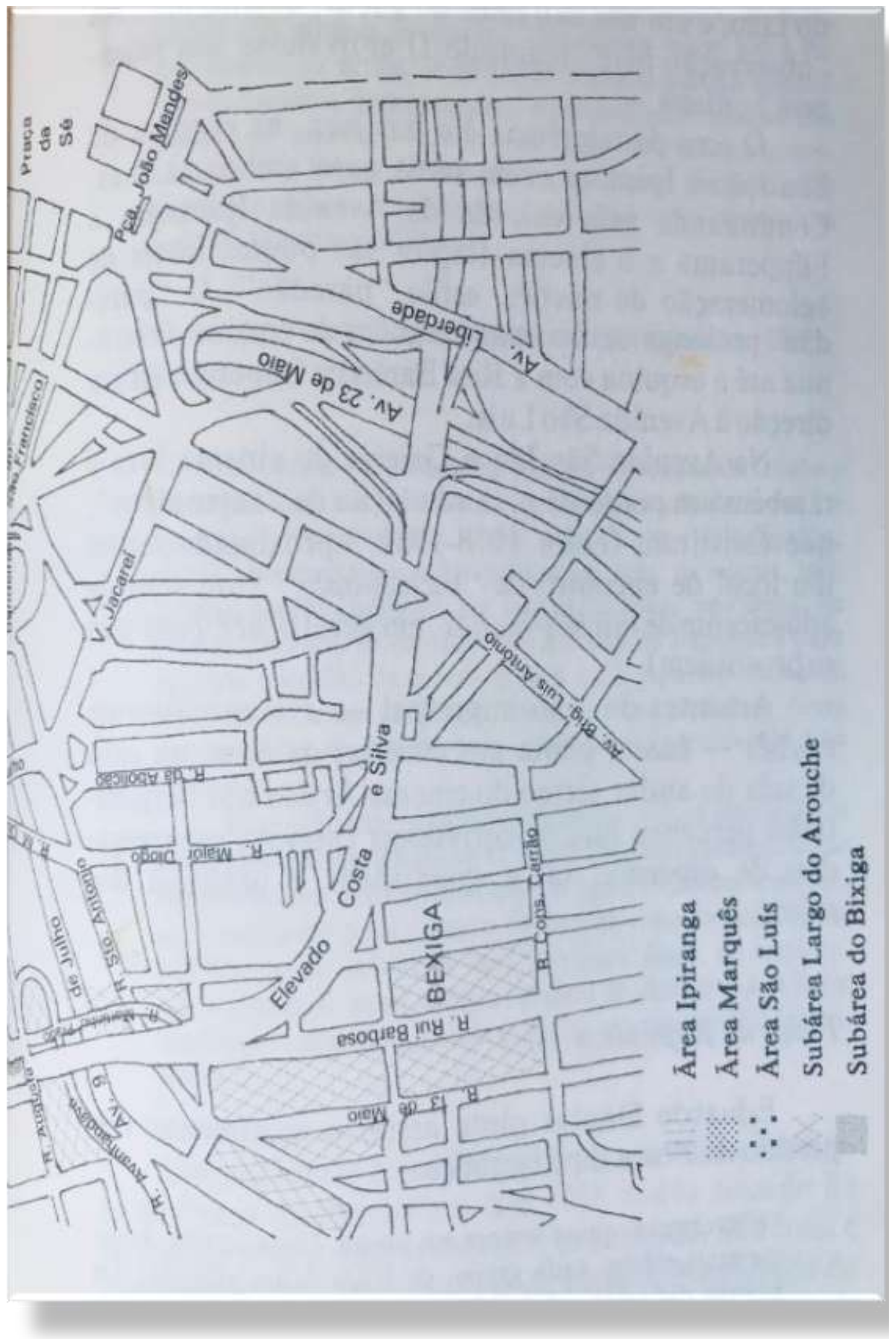

Territórios e Populações: “O Gueto Gay Paulistano” (PERLONGHER, 1987a, pp. 110-111). 
Vale ressaltar que falar da homossexualidade, como diz Néstor Perlongher, “[...] no es sólo hablar de goce sino también de terror" (1997b, p. 30): "El sufrimiento es muy grande antes de llegar al goce" 46 (Idem, p. 29), afirma em epígrafe ao ensaio "El sexo de las locas" $(1984)^{47}$. Como no caso Chrysóstomo, a homossexualidade foi, durante muito tempo, classificada no quadro psiquiátrico das perversões mentais, isto é, categorizada no paradigma de perturbação psíquica -, sendo castigada por meio de uma série de códigos disciplinares, como numa "pesadilla cotidiana"; e neste trabalho a discussão parece confirmar o exposto somando-o a um paradoxo sem precedentes, isto é: à recusa da homossexualidade que, em determinadas circunstâncias, se dá entre prostitutos viris. Máximas do tipo "Eu cobro para não passar por bicha" (1987a, p. 24) ou "[...] a bicha é a sola do sapato do macho" - como assinalado por Peter Fry a partir do relato de uma vítima deste modelo de relacionamento sexual intermasculino (1982 apud PERLONGHER, 1987a, p. 22) -, são condutas que sugerem a distância que cruza as relações entre travestis/homossexuais e os michês de rua. Muito embora a experiência do michê esteja inscrita no quadro das experiências homossexuais, a diferenciação proposta acaba por marginalizar aqueles ao mesmo tempo que gera uma série de conflitos, polêmicas e gozações.

A contrapelo do que sugere a figura do travesti e do homossexual, nas análises desenvolvidas por Néstor Perlongher o prostituto viril tende a "[...] não abandonar a cadeia discursiva e gestual da normalidade [...]" (Idem, p. 21), trata-se, entre outros aspectos, de construções estruturadas sem que, com isso, seja necessário “[...] um corte

\footnotetext{
${ }^{46}$ Epígrafe de Dante Panzeri. (Ver: PERLONGHER, 1997b, p. 29).

${ }^{47}$ Embora o ensaio tenha sido publicado em maio de 1984, no número 28 da Revista El Porteño, trabalhamos com a versão que consta em Prosa plebeya: ensayos, que é de 1997.
} 
na aparência masculina [...]" tida como "normal" (Idem). Contudo, restringimos nossa discussão à "normalidade" descrita pelo antropólogo. Em primeiro lugar, para Néstor Perlongher a prostituição do michê poderia ser enquadrada naquilo que designa como "prostituição de gêneros maiores", aspecto que confirma a existência de um gênero menor no universo da prostituição masculina. Em segundo lugar, esta permanente contradição insere no debate dois tipos bastante específicos, assim descritos pelo autor: de um lado, a feminilidade do travesti aparece revelada através “[...] daqueles rostos que o cinema norte-americano fabrica centímetro por centímetro quadrado até atingir a mais fria perfeição" (1987a, p. 19): “Os cabelos louros lhe caíam em cascata até os ombros. A pele do colo era sedosa e bronzeada - os seios, grande demais, eram vigorosamente eretos. Voltando ao rosto: os zigomas [...] repuxavam levemente os seus lábios, dando ao conjunto um ar atrevido que os olhos completavam [...]" (SILVA, 1981, p. 4 apud PERLONGHER, 1987a, p. 19). Por outra parte, a masculinidade do michê aparece assim transcrita:

Em Nossa senhora das Flores, Genet descreve assim o encontro de Seck Gorgui com Divina (a "bicha" do relato); Seck precisava de dinheiro: "Ele mantinha-se ereto, firme, se bem que um pouco caído para trás, imóvel e sólido na posição de um menino de sacola nas costas, lutando sobre os trêmulos joelhos para mijar contra o nada, ou na pose [...] Colosso de Rodes, que é a pose mais viril dos sentinelas: coxas abertas pousadas sobre botas, entre as quais, elevando-se quase até a boca, eles agarram as mãos fechadas um fuzil baioneta". (GENET, 1983, p. 183 apud PERLONGHER, 1987a, p. 19).

Revela-se, com isto, uma espécie de submundo no universo da prostituição viril, no qual o michê de rua representa certa tendência à constituição de "entidades fechadas e exclusivas" (1987a, p. 23). Isto ocorre como consequência das necessidades impostas à profissão: os michês entrevistados ressaltam o fato de que "gabar-se da heterossexualidade" acaba sendo um atributo que soma "pontos" perante os clientes que 
“[...] em grande parte, procuram rapazes que não sejam homossexuais" (Idem, p. 23). Observa-se, neste sentido, a "prostituição viril", o "negócio do michê", enfim, a "prostituição dos rapazes" enquanto denominações que convocam algum tipo de contiguidade com determinados códigos e territórios, conforme anota Néstor Perlongher.

\subsubsection{O confinamento do desejo: "operação limpeza"}

A "noite" exige a assinatura de um contrato: em alguns casos, a prostituição viril deve investir no que Néstor Perlongher chama de "autoprodução de virilidade", embora, neste negócio, ganhar e perder representem os dois lados de uma mesma moeda, sobretudo porque: “Ao que parece, esta autoprodução de virilidade não parece ter tido resultados práticos tão felizes [...]” (1987a, p. 85). A concepção moderna de cidade operativizada desde a perspectiva da descentralização -, dissimula o estabelecimento de campos dominantes, cuja divisão do espaço estrutura fronteiras visivelmente demarcadas: cria-se a "região moral", como expõe Néstor Perlongher, uma espécie de território que não pode ser mapeado a partir da “[ [...] centralidad resplandeciente de la urbe sino en los brillos opacos del margen [...]" como "[...] áreas de perdición y vicio de las grandes ciudades" [...] ambientes aislados, en los cuales los impulsos, las pasiones y los ideales vagos reprimidos se emancipan de la moral vigente [...]" (PERLONGHER, 1997b, pp. 45- 50);

Estudando a figura do narrador na literatura brasileira contemporânea, Jaime Ginzburg (2012) explicita que: “O centro [...] é entendido como [...] a política conservadora, a cultura patriarcal, o autoritarismo de Estado, a repressão continuada, a 
defesa de ideologias voltadas para o machismo, o racismo, a pureza étnica, a heteronormatividade, a desigualdade econômica [...]" (p. 201). Para além da contraposição explícita às pulsões múltiplas e heterogêneas, a concepção de cidade com que nos brinda Néstor Perlongher em O negócio do michê: a prostituição viril, delimita o que podemos de chamar de criação de zonas de confinamento, tanto do desejo quanto dos demais aspectos que expressam a vida em sociedade. No caso do desejo, entretanto, notam-se elementos ambivalentes, os quais não só envolvem “expressões discriminatórias" e "impulsos reprimidos pela civilização" (1987a, p. 47), como também sugerem uma base oculta, estigmatizada e marginal.

O autor de "Uma tendência na Literatura Brasileira: a narrativa de confinamento" (2012) discute a teoria do confinamento a partir da leitura de narrativas da literatura brasileira contemporânea. Em sentido estrito, Jaime Ginzburg aponta que o confinamento aparece como conceito vinculado à situação física de um corpo, expressando a condição do corpo que "não pode sair de onde está", como no caso das prisões, internatos e manicômios. Neste sentido, o controle institucional supõe o controle corporal e, consequentemente, a total restrição da liberdade. Nos exemplos apresentados por Jaime Ginzburg o controle é identificado como produto de arquiteturas, de estruturas sólidas e concretas, que podem ser capturadas pelos olhos: a camisa de força, as paredes, os altos muros dos presídios, as cercas elétricas, enfim, uma infinita "rede de proteção" que sustenta e mantém o poder estatal. Neste sentido, questionamos: será que esta ideia de confinamento pode ser estendida à leitura que fazemos do trottoir realizado na prostituição viril? 
Embora não muito óbvia, a questão consistiria em vincular o conceito ao que o crítico literário chama de "cadeias metafóricas de confinamento". Nestas "cadeias", as possibilidades de interpretação do conceito passam a operar de modo expandido. O contexto social surge pautado por uma série de antagonismos a partir dos quais observase a manifestação - igualmente - restrita da liberdade. Para Jaime Ginzburg, além de expor a ausência de ética em que vive o Estado, estas situações incluem a “destruição" da vida social coletiva - é neste aspecto que reside a perseguição ao negócio do desejo.

Néstor Perlongher resgata a conhecida “operação limpeza”, ocorrida no centro da cidade de São Paulo, no início dos anos 80, a fim de revelar estes espaços em que o controle exerce despotismo e desrespeito às liberdades individuais. Em seu estudo problematiza o argumento apresentado pelo delegado da Seccional Sul da Polícia, Paulo Boncristiano, em abril de 1980, ocasião em que sugere o confinamento dos travestis: “[...] Serão alguns quarteirões, depois de determinada hora da noite, quando o comércio já fechou e estão abertos somente os bares e os inferninhos. Em São Paulo já temos o lugar, as chamadas Boca de Luxo e Lixo, proximidades da Avenida Rio Branco, bairro da Santa Ifigênia, e Rua Amaral Gurgel, baixos do elevado Costa e Silva'. (PERLONGHER, 1987a, p. 92). Na ampliação desta rede, afirma o Coronel da PM, Sydney Gimenez Palácios: “As rondas policiais recolherão os travestis e na triagem os primários serão liberados e aconselhados a frequentar somente determinadas ruas [...]” (Idem). Este enquadramento provisório, diz Néstor Perlongher, sujeita o desejo homossexual a inúmeras penalidades, cuja “camisa de força” é absolutamente invisível.

A “operação limpeza" ganhava eco. Aos poucos, lideranças homossexuais e intelectuais ligados ao jornal Lampião - em cuja edição trabalhou Antônio Chrysóstomo, 
antes de ser preso -, manifestavam-se sobre as agressões sofridas na época. De acordo com um dos jornalistas, e membro do Lampião, João Silvério Trevisan:

Tal plano pretende juntar as forças da polícia civil e militar [...] para, entre outras coisas, tirar os travestis dos bairros residenciais, reforçar a Delegacia de Vadiagem e destinar um prédio (o desativado prédio do Hipódromo) para abrigar especialmente homossexuais. No fim de maio, é transferido para a Terceira Seccional (Centro) um delegado que se vangloria de ter, na década passada, expulsado as prostitutas de São Paulo e criado a zona de meretrício em Santos. Nome do personagem: José Wilson Richetti. (TREVISAN, Lampião, julho de 1980 apud PERLONGHER, 1987a p. 93).

Os métodos utilizados na operação desatada por José Wilson Richetti contaram com o "apoio estratégico de comerciantes e vizinhos da área" (1987a, p. 93), os quais não só remeteram "cartas e telegramas de apoio" como também elaboraram cerca de "60 abaixo-assinados com cerca de duas mil assinaturas": "Os moradores não se limitavam a protestos passivos: costumavam até jogar sacolas de excrementos e garrafas contra os gays do largo" (Idem). A arbitrariedade dos atos violentos -verbais, físicos e psíquicos-, ganhou inúmeras proporções,

'[...] O próprio Richetti [...] esmurra as costas ou a cabeça das mulheres que deixam a prisão [...]. Um travesti relata como Richetti [...] abriu uma gaveta e fechou-a violentamente, prendendo seus seios [...]. Na esquina da Rego Freitas com Major Sertório, investigadores tentam tirar a dentadura de um travesti, para recolher a gilete aí escondida. Como ele jura aos berros que seus dentes são naturais, é espancado e tido por mentiroso'. (TREVISAN, Lampião, julho de 1980 apud PERLONGHER, 1987a, pp. 93-94).

Os níveis de repressão foram intensificados, sobretudo com relação aos travestis, considerados como uma espécie de "subcultura dentro do homossexualismo": "[...] você tem que distinguir o homossexual do travesti [...]" (p.97), ressaltava o primeiro secretário de segurança do governo Montoro, Manoel José Pimentel. Para o secretário, o travesti 
deveria ser visto menos como um problema policial que social. Dessa forma, para além de contundentes, os argumentos apresentados pelos regimes de poder passaram a produzir “esporádicas blitz” contra desejo, capturando não só “as fugas desejantes”, como também atacando "[...] gays, michês, bichas, travestis [...]" (p. 103).

A "região moral", constituída por "bocas" ou "pontos" de prostituição, passava a ser entendida como uma espécie de microterritório em que se desdobravam o trottoir e, consequentemente, os encontros com finalidade erótica/sexual. No ensaio "Avatares de los muchachos de la noche", destaca Néstor Perlongher:

[...] la denominación vernácula de "Boca" se asocia a un foco de emisión de flujos que, además de aplicarse a los sitios de prostitución diferenciada en Boca do Luxo (Lujo) para la alta prostitución y Boca do Lixo (Basura) para la baja prostitución -, se extiende a otras transacciones marginales: Boca do Fumo (tráfico de marihuana), etc. Tal inserción del circuito homosexual del centro de San Pablo en los corredores de las "Bocas" manifiesta, por añadidura, cierta relación de contigüidad entre las marginalidades sexuales (que atentan contra el orden de la reproducción sexual) y económicas (que atentan contra el orden de la producción social) [...]. (PERLONGHER, 1997b, p. 46).

Observa-se no acantonamento do desejo a arquitetura de estruturas que consolidam o encarceramento das subjetividades ao mesmo tempo que seguem regulamentando as estratégias de controle desenvolvidas pelos dispositivos de poder do Estado - aspectos que se confirmam com o fato de que os agenciamentos promovidos pela "operação limpeza" administraram várias

[...] mudanças na distribuição dos espaços do "gueto gay" e das "bocas" em geral.

O resultado mais eloquente da "limpeza" foi a supressão do Largo do Arouche como ponto focal de concentração das populações homossexuais. Os gays foram acantonados na Rua Marquês de Itu, entre as ruas Bento Freitas e Rego Freitas, na porta da boate H.S. No pedaço - literalmente denominado de 'gueto gay' pelos seus 
frequentadores - perambulava uma população exclusivamente gay [...]”. (PERLONGHER, 1987a, p. 99).

Por sua parte, as análises de Néstor Perlongher revelam não só a agonia que atravessou a prostituição viril na cidade de São Paulo, durante os anos 80, como também abrem uma série de precedentes para que sejam pensados o controle institucionalizado e as mais distintas, - às vezes, invisíveis - cadeias de confinamento que se entretecem "por los instersticios de la ciudad" (PERLONGHER, 1997b, p. 45). De modo geral, demonstra-se o grande valor que tem para o Estado a constituição de barreiras, limites e fronteiras. O confinamento tende a dispersar toda e qualquer possibilidade de fragmentação do corpo, cuja ruptura fundamenta os efeitos de despersonalização e consequente perda de identidade, logo, emancipação da moral dominante, conforme anota Néstor Perlongher.

Em certa medida, acreditamos que a busca por esta "territorialidad perversa" (Idem), isto é, pelo confinamento do desejo, parece ter fracassado ante a transgressão que configura a "fuga libidinal”, que atua não como um "reverso perverso de la ley", já que, antes, consiste numa "[...] territorialidad itinerante, legible en las redes de circulaciones y encuentros entre los sexos [...]" (p. 50), minando dessa forma “[...] los mecanismos de normalización institucional" (p. 55). A esta "modalidade" do confinamento agregam-se outras, dentre as quais o discurso de "controle clínico sobre o desejo", conforme discutiremos a seguir. 


\subsection{Formas de controle: o fantasma da $\operatorname{AIDS}^{48}$}

Às "cadeias de confinamento" expostas soma-se o discurso de uma histeria moralista ou apocalíptica - estimulado não só pela "origem nebulosa" da enfermidade como também, e principalmente, pela "indecisão clínica", que tende a favorecer "a proliferação de mitos", como condensa Néstor Perlongher em que O que é AIDS (1987, p. 38). Para o autor, a AIDS aparece como uma delas, isto é, como a contraparte do confinamento, como uma espécie de "penalidade" que reverte os efeitos da Revolução Sexual.

A partir de la irrupción del Sida, un dispositivo mucho más potente está montándose en el contexto de la creciente medicalización higienista de la existencia [...] con todas sus violencias interiores y sus complejas paradojas, y la imposición de un control clínico sobre el deseo, que mide la vida a partir de un patrón extensivo y normativo. (PERLONGHER, 1997b, p. 56).

Em “A mais justa das saias”, Pequenas epifanias $(2014)^{49}$, Caio Fernando Abreu menciona o preconceito por que passaram os homossexuais logo das primeiras manifestações da enfermidade. Diz o autor: “[...] 'Não é possível' - pensei - 'Uma espécie de vírus de direita, e moralista, que só ataca aos homossexuais?”, e rebate afirmando que a mais grave das contaminações é a da AIDs psicológica. Assinala o cronista:

[...] começaram as confusões. A pseudotolerância conquistada nos últimos anos pelos movimentos de liberação homossexual desabou num instantinho. Eu já ouvi - e você certamente também - dezenas de vezes frases tipo "bicha tem mesmo é que morrer de aids". Ou propostas para

\footnotetext{
${ }^{48}$ Alusão às primeiras reflexões do autor em $O$ que é AIDS (1987).

49 Inicialmente, Caio Fernando Abreu publicou a crônica no jornal O Estado de São Paulo, 23/3/1987. Pequenas epifanias acabou sendo publicada em 1996, pouco depois da morte do escritor, e conta com seleção de Gil França Veloso.
} 
afastar os homossexuais da "sociedade sadia" - em campos de concentração, suponho. Como nos velhos e bons tempos de Auschwitz? Tudo para o "bem da família", porque afinal - e eles adoram esse argumento - "o que será do futuro de nossas criancinhas?". (2014, p. $38)$.

Sete anos após a publicação desta crônica, mais especificamente em 1994, Caio Fernando Abreu retorna de uma viagem ao exterior. No regresso, percebe sintomas atípicos em seu corpo. As primeiras evidências clínicas da enfermidade se alastravam: febre, erupções avermelhadas na pele, infecções, tosse ininterrupta, etc. Ao fazer o teste, o cronista descobre ser portador do vírus, o que num primeiro momento não foi motivo de grandes transtornos. Contudo, os efeitos da crise psicológica não tardariam em aparecer. Escreve Milena Mulatti Magri (2012, p. 172):

[...] A confirmação da doença é divulgada pelo próprio autor, em uma série de crônicas conhecida como "Cartas para além dos muros". Ao saber do resultado do exame, Caio Fernando Abreu, num primeiro momento, reage calmamente. Telefona para amigos e parentes para dar a notícia. Logo depois, em seu apartamento, na companhia de amigos, o escritor tem uma crise de nervos devido ao impacto psicológico da doença - uma sentença de morte, até então, além da exclusão social a que estaria sujeito.

Como no caso de Néstor Perlongher, por detrás das crises e do profundo sentimento de melancolia experimentados pelo cronista, observa-se o medo procedente de uma série de “[...] projeções apocalípticas, que chegam até a prever a extinção da humanidade [...]" (PERLONGHER, 1987b, p. 8). Após o choque inicial, a crise ganhava proporções inauditas, já que havia se convertido numa espécie de coextensão entre doença e espaço: o boudoir do escritor acomodava e reforçava os estragos psíquicos causados pela doença, dentre os quais o "medo, a rejeição, o estigma” (SILVA, 1991, p. 1). Além dos muros invisíveis, evidenciados nos discursos moralistas da época, Caio Fernando 
Abreu descreve o quarto do Hospital Emílio Ribas, em São Paulo, onde foi internado logo depois de sua primeira crise. Lemos em "A AIDS nas crônicas de Caio Fernando Abreu” (2012):

\begin{abstract}
A janela do quarto ficava de frente para a Avenida Doutor Arnaldo, onde se situa o muro do Cemitério do Araçá, em frente à avenida. A referência aos muros do cemitério, no título da série de crônicas, já deixa entrever que a possibilidade da morte iminente atuaria como um divisor de águas em sua vida: para além do muro, para aquém do muro; da doença; da vida e da morte. (MAGRI, 2012, p. 172).
\end{abstract}

Outro aspecto que chama atenção refere-se ao fato de que, assim como Néstor Perlongher, Caio Fernando Abreu insistia na importância do esclarecimento, sobretudo porque sabia que já naquela época a AIDS matava menos que outras doenças, até mais conhecidas e investigadas. De acordo com Néstor Perlongher: “[...] Há mais probabilidade de se morrer vítima de um atropelamento na rua do que de AIDS" (1987b, p. 9). Entretanto, o horror ao corpo se expressava como repúdio às contorções do prazer e do gozo - aspectos que, como sugere Néstor Perlongher em "Avatares de los muchachos de la noche", dizem respeito a uma obsessão pelo pênis, pela penetração o pela sucção, enfim, "[...] por las conexiones pene-ano-boca [...]" (1997b, p. 49), que atraem os dipositivos da moral dominante.

Além da primeira denominação dada de modo extraoficial à doença - (Gay Related Imune Deficiency ou Deficiência Imunológica Relacionada à Homossexualidade, GRID) -, falava-se em "câncer gay" e em "peste rosa", conforme assinala Néstor Perlongher (1987b, p. 8). Susan Sontag (2007) aponta que a “[...] doença é a zona noturna da vida, uma cidadania mais onerosa [...]" (2007, p. 11). De acordo com a autora, até mesmo as denominações atribuídas a algumas doenças - lembrando que se refere 
essencialmente à tuberculose e ao câncer -, parecem ser portadoras do estigma, isto é, de um "poder mágico":

Em Armance (1827), de Stendhal, a mãe do herói se recusa a falar "tuberculose", por temor de que pronunciar a palavra acelere o curso da moléstia do filho. E Karl Menninger observou (em The vital balance) que "a própria palavra 'câncer' é vista como capaz de matar certos pacientes que não sucumbiram (tão rapidamente) ao mal de que padecem". (SONTAG, 2007, p 13).

A autora enfatiza, ainda, que a atmosfera de ficção científica construída por meio de metáforas - na maioria das vezes militares -, para tratar de doenças como a tuberculose e o câncer, tornou-se mais acentuada no caso da AIDS. Destacava-se, desta vez, o invasor como um tipo de vírus oportunista, que ataca de fora prá dentro e contra o qual se deve lutar, contra o qual se deve travar uma guerra. Além disso, sublinham os discursos de controle: "[...] um exército de doenças oportunistas, normalmente contidas pelo sistema imunológico sadio, ataca o organismo" (Idem, p. 92, grifos nossos).

Susan Sontag ressalta o fato de que na época defendia-se que a AIDS era “[...] uma doença causada não apenas pelos excessos sexuais, mas também pela perversão sexual [...]”, principalmente porque se sustentava que: “[...] a transmissão heterossexual da doença é extremamente rara e improvável [...]” (Idem, p. 98). Neste sentido, as "conversações cotidianas" de índole "fortemente emocional", de acordo com Eni Leide Silva (1991, p. 5), além de constrangedoras, levantavam uma polêmica extremamente complexa ao mesmo tempo que favorecia a polarização da sociedade: a AIDS passou a ser considerada como uma doença, essencialmente, homossexual" (PERLONGHER, 1987b, p. 9). “Sobre a AIDS colocaram-se preconceitos”, afirma Silva (Idem). 
A falta de tratamento efetivo para a doença aliada às "[...] dificuldades que adiam concretamente a concreção desta ilusão" (1987b, p. 35) - verificada por Néstor Perlongher há mais de trinta anos -, apenas ampliava o encarceramento da vida: limitada, de modo paulatino, aos "planos de prevenção". De acordo com Néstor Perlongher, a tarefa médica consistia em "aconselhar" a sociedade, sugerindo determinados comportamentos médicos e paramédicos:

- reduzir o número de parceiros: os mais promíscuos estarão mais expostos ao contágio; pela lei da probabilidade;

- evitar contato com o esperma: conselho dirigido particularmente aos homossexuais masculinos, principal "grupo de risco" [...];

- usar camisa-de-vênus (camisinha) [...];

- utilizar seringas descartáveis individuais: recomendação para os usuários de drogas injetáveis;

- abster-se dos atos considerados de maior risco de contágio: [...] coito anal, vaginal, relação bucogenital, buco-anal e todos os que implicam troca de secreções. (PERLONGHER, 1987b, p. 36).

Além desta série de "conselhos" e da imagética própria da medicina - "terrorista" nas palavras de Perlongher -, a mídia desempenha papéis decisivos que espetacularizam a morte: “[...] mostram-se, por exemplo, cenas de dois rapazes gays de mãos dadas, e logo depois um paciente carcomido pelo sarcoma de Kaposi” (p. 53). Neste sentido, se antes o trottoir da prostituição viril, restringia-se a determinadas "bocas" do centro da cidade, neste momento, entretanto, observa-se "o progressivo esvaziamento do centro da cidade" (p. 61). A suposta "prevenção" convertia-se em repressão aos "gays, bichas, michês, travestis e todo tipo de entendidos", arrastando-os, duplamente, à clandestinidade.

No debate apresentado em $O$ que é AIDS, Néstor Perlongher retoma a problemática do disciplinamento das práticas sexuais veiculado, principalmente, pela política preventiva embutida nos "conselhos médicos". Além disso, o autor se propõe a 
pensar de que modo estes discursos, somados à desinformação da sociedade, tornam-se capazes de afogar o desejo homossexual, interpretado à luz de uma normalidade difusa e banal de um discurso sanitário perverso e excludente. Seria relevante perguntar, afinal “[...] por que justamente o homossexual constitui o alvo dessa programática" no interior destes discursos sonorizados e insistentes? (Idem, p. 76). Aparentemente, a juridisção moral daria conta da complexidade apresentada no questionamento, só que, por outro lado, o desejo expressa "uma incontornável resistência", cuja complexidade "[...] escapa às prescrições segundo um impulso que não é racional nem formalizável" como no caso da “[...] frieza da análise técnica” (p. 77): “A perspectiva médica não costuma levar em conta esses labirintos do desejo" (p. 89), sobretudo porque o considera a partir de uma perspectiva hegemônica. Néstor Perlongher destruiu “[...] los sentidos achatados [...]", levando "[...] a la bizarría las altas cumbres de la palabra [...] para acercarlas a los márgenes” (CANGI, 2000a, p. 48), cujos “[...] deseos sin culpabilidad [...] abren paso por los intersticios moleculares y por debajo del autoritarismo y la violencia de Estado”, ao mesmo tempo que oferecem "[...] otras dimensiones a la existencia" (Idem, p. 47).

Néstor Perlongher estabeleceu importantes graus de ruptura com a ordem. Neste sentido, a revolução - diria o autor - é um ato de amor: "Alcanzar el devenir revolucionario de las personas no consiste en comenzar por definir una identidad, sino construir la posibilidad de una mutación, en producir un plano de delirio, una fuga de la normalidad, una subversión de las fábricas de subjetividad [...]” (p. 68) ${ }^{50}$. Para Javier

\footnotetext{
${ }^{50}$ Debate aprofundado, sobretudo, nos ensaios escritos ao longo dos anos 80 e que compõem o capítulo "Deseo y política", de Prosa Plebeya: ensayos (1980-1992), a saber: "Nena, lleváte un saquito" (1983); "El sexo de las locas" (1983); "Matan a una marica" (1985); "Deseo y violencia en el mundo de la noche" (1987); "El orden de los cuerpos" (1987); "Avatares de los muchos de la noche" (1989); "La fuerza del carnavalismo" (1988); "El síndrome de la sala" (1988); "Los devenires minoritarios" (1990); "Historia del Frente de Liberación Homosexual" (1985) e "La desaparición de la homosexualidad" (1991). Além, é claro, dos poemas que integram Alambres (1987).
} 
Gasparri (2015, p. 7) a reconfiguração do problema desdobra-se em outro, ainda mais decisivo: “[...] de una política-como-deseo-de-poder a una política del goce” - onde observamos Néstor Perlongher explicitar os predicados de sua poética plebeia, ainda que como exposto na epígrafe que introduz o ensaio "El sexo de las locas", Néstor Perlongher sabia que "El sufrimiento es muy grande antes de llegar al goce" (apud PERLONGHER, 1997b, p. 29, grifos nossos).

Christian Ferrer e Osvaldo Baigorria assinalam que: “[...] el deseo para Perlongher es un cruzado que vulnera las fronteras de la forma, la conyugalidad, el sedentarismo, la consaguineidad" (1997, p. 9), sobretudo porque tanto em Prosa plebeya: ensayos (19801982) quanto em $O$ negócio do michê: a prostituição viril e $O$ que é AIDS o escritor subverteu a obsessão “[...] por las conexiones pene-ano-boca [...]” (1997b, p. 49), que atraem os dipositivos da moral dominante, sugerindo ainda uma torção, isto é, uma constante blitz contra as formas de repressão e confinamento.

A partir dos textos reunidos e analisados neste capítulo percebeu-se a existência de corporalidades inscritas nas barras da lei: de um lado, o julgamento de um preconceito; de outro, este mesmo preconceito assumindo dimensões extremamente complexas no interior de discursos higienistas e excludentes. Nestes mesmos textos, os usos subversivos do corpo resistem a determinadas formas de "organização do organismo", segundo as quais "[...] a boca para comer, o cu para cagar, o pênis para a vagina, etc" (PERLONGHER, 1987b, p. 83). “O coito anal derruba o capital” salientavam os gays do gueto paulista no auge dos movimentos contestatórios. Mesmo explorando as constantes blitz contra o homossexual e os agravantes da AIDS como mais uma forma de perseguição e confinamento, Néstor Perlongher insistia em que o medo da morte não confiscasse as 
intensidades da vida: "Seria preciso, talvez, conceber uma política sexual diferente, que não desconhecesse a multiplicidade dos desejos eróticos nem tentasse disciplinar pedagogicamente [...] os prazeres" (Idem, p. 91, grifos nossos). 


\section{Capítulo IV - Do trottoir ao boudoir do poeta; ou cartografias corporais em transe, experimentação e performance}

\subsection{Os poemas de Perlongher prosaico}

Para Domingos Carvalho da Silva não é incomum localizar nas dobras da poesia indistinções taxonômicas, que ignoram as antinomias entre prosa, poesia/poema. Em Uma teoria do poema (1989), além da decantação formal atribuída à expressão poética, o escritor traz à tona algumas considerações a partir das quais seria possível o estabelecimento do estatuto poético de determinados textos. Domingos Carvalho, no entanto, não deixa de expressar sua crítica quanto ao radical racionalismo da composição que, em determinadas circunstâncias e em favor de uma operação linguística exclusivamente poética $^{51}$, pretendeu enclaustrar a poesia numa arte das ideias. Este, contudo, não é o principal debate ao qual se dedica o crítico, uma vez que procura refutar o que entende como formas de supressão do valor poético. Domingos Carvalho demonstra certa perturbação estética ao observar que “[...] a ideia poética (isto é, a poesia)” está "fora da poesia":

Intentemos um resumo: a prosa literária é pormenorizada, irradiada, analítica; a expressão poética é simétrica, contida, sintética. Na prosa há a função de significar através das palavras, o pensamento; na poesia as palavras não traduzem, necessariamente, um pensamento prévio. $\mathrm{O}$ pensamento prosaico traduz-se em palavras; o pensamento poético resulta das palavras. A significação do poema não está propriamente na sua correspondência com ideias, mas no seu modo de ser como estrutura global de palavras, sons, conceitos e ritmos. (SILVA, 1989, p. 68).

\footnotetext{
${ }^{51}$ Ocasião em que o escritor recupera elementos como as regras de ritmo, os critérios de seleção de palavras, usos de tropos, bem como de antíteses, etc., fazendo a expressão poética desaguar em extrema condenação.
} 
Nota-se que para o crítico a expressão poética detém qualidades de síntese e contenção, não se desdobrando, como a linguagem da prosa, em minúcias [...]”. Convergimos com o crítico quando assinala: “[...] que a linguagem do poema é poliédrica, como um cristal [...]" (Idem, p. 66). Discordamos, porém, quando levando em conta o trabalho de exaustão com a palavra desenvolvido pelo poeta, chegamos à impossibilidade dos convencionalismos e estruturas rígidas como tentativas de definição de um valor. Os desvios da linguagem, se não indispensáveis, são os meios em que se concentram os poetas, a fim de expressar a ambiguidade, multivocidade, enfim, a plurissignificação, bem como os múltiplos deslizamentos, arbitrariedades e fragmentação da língua convocados pela palavra. Em Filosofia da caixa preta: ensaios para uma futura filosofia da fotografia, Vilém Flusser afirma tais questões ao sugerir que a hierarquia dos códigos tem se perturbado, evidenciando com isto a dissolução de máximas que impuseram seus pesos e medidas ao enunciado poético. Paralelamente, a condição dos textos - diz o filósofo checo - passou a expressar dimensões que reconfiguram o mundo através de imagens rasgadas e incongruentes.

Nas três últimas antologias de Néstor Perlongher, vale destacar, perpassamos o território assinalado pelo filósofo checo: de um lado, com Hule ${ }^{52}$; de outro, com Aguas aéreas e El chorreo de las iluminaciones. A contrapelo de determinados paradigmas apresentados pela crítica, os poemários que conformam a fase final da poética perlongheriana sugerem o trabalho com elementos incongruentes e imagens rasgadas. Uma metáfora é sempre a possibilidade de outras. A metonímia atravessa e fragmenta a palavra instaurando relações improváveis. Por outro lado, hipálages, contradições e

\footnotetext{
${ }^{52}$ Consideramos Hule como a antepenúltima obra do autor, tendo em vista o fato de que foi escrita depois de Parque Lezama. No entanto, em decorrência destas "jugarretas editoriales", como enfatizado por Néstor Perlongher, acabou sendo publicada antes de Parque Lezama.
} 
estruturas antitéticas caminham lado a lado de oximoros, que garantem enunciados saturados de ironia e sarcasmo. Se para Domingos Carvalho da Silva a tensão entre prosa e poesia verificava-se através de enquadramentos descritivos estáveis, no caso perlongheriano estas estruturas não só passam pelo funil diluyente da experimentação linguística, como também são implodidas a partir modo como o poeta arranja seus versos e estrofes. Néstor Perlongher combate a máxima apresentada pelo crítico de que: “[...] a expressão poética é simétrica, contida, sintética" (Idem), como observaremos nas análises a seguir, e como constatamos nos dois trechos extraídos da entrevista que Néstor Perlongher concede a Luis Chitarroni, em 1988. Na ocasião, o poeta argentino convalida sua perspectiva em torno a escritura de textos poéticos:

1. [...] yo diría que se trata de darle forma a la fuerza. O de suscitar una fuerza dionísiaca, de desestructuración, de éxtasis, y turbulencia donde el trabajo del poeta consiste en darle una forma para que esa fuerza no se disipe (PERLONGHER, 2004, p. 302).

2. [...] Si alguien tiene que escribir un poema, tiene que hacerlo de la manera más linda, ¿no?, Es una cuestión del suburbio: ¿cómo se van escribir poemas para decir lo que dice todo el mundo? ¿Qué gracia tiene? La palabra imperativo es ridícula, pero si hubiera algun cope, algun mambo, sería ese: convertirlo todo en joya. Que todo replandezca, brille". (PERLONGHER, 2004, p. 310).

Neste sentido, a "maquinaria de destrucción"53 perlongheriana não se presta ao alinhamento formal e enclausurante firmado por determinadas vertentes da crítica. Antes,

O labor do poeta [...] se realiza com a prática da extrema torção da linguagem, que envolveria, por exemplo, a preocupação com a combinação sonora, a seleção lexical, a mescla de palavras pertencentes a outros idiomas, a condensação de termos, a substituição de um termo por outro, com o qual mantém uma relação semântica distante, a intertextualidade, a intratextualidade, o rompimento da estrutura do verso, etc. (FERRO, 2010, pp. 33-34).

\footnotetext{
${ }^{53}$ Imagem recorrente nas análises do crítico Nicolás Rosa.
} 


\subsection{Hule: erotismo, desejo e o trottoir do poeta}

Hule (1989) figura como obra de transição de Néstor Perlongher, em que este obedece os distintos fluxos da escritura. Por um lado, verifica-se tanto o retorno a debates centrados em conceitos como desejo e sexualidade ${ }^{54}$ presentes nas duas primeiras antologias publicadas pelo poeta, como também o diálogo com questões acumuladas na escritura de Parque Lezama ${ }^{55}$ - obra em que o poeta confronta a "[...] proliferación de formas barrocas [...]" que “[...] constituyen una verdadera tendencia de revitalización barroca [...]" (ROSA, 1983 apud GARCÍA HELDER, 1987, pp. 24-25) com os elementos procedentes do neobarroco cubano. Por outro lado, anuncia problemáticas apresentadas em Aguas aéreas e na escrita terapêutica de El chorreo de las iluminaciones. Vale mencionar que questões de ordem biográfica tornam-se igualmente indispensáveis para a compreensão desta fase do poeta, tendo em vista que invertendo a máxima aristotélica de que "a arte imita a vida", no caso de Néstor Perlongher ironicamente a vida imitou a arte. Isto porque tendo discorrido desde o início da década de 80 sobre os limites impostos ao desejo - limites entendidos como formas de controle, que encerram e padronizam as formas de desejo -, o escritor teve de lidar com a AIDS e com o peso assinalado pela enfermidade, ainda muito recente na época ${ }^{56}$. Em "Disciplinar os poros e as paixões",

\footnotetext{
${ }^{54}$ Questões que passam a ser observadas em Hule com especial atenção aos aspectos constitutivos da estética kitsch, já que é a partir das ferramentas que esta oferece que se torna possível visualizar os exageros do estilo, por exemplo, como mais uma escolha, ou seja, como mais um procedimento linguístico e de estilo adotado por Néstor Perlongher.

${ }^{55}$ Embora Parque Lezama represente o aperfeiçoamento dos procedimentos de experimentação linguística até então assumidos pelo poeta ao mesmo tempo que estabelece o diálogo com os cubanos Lezama Lima e Severo Sarduy - especificamente com os elementos constitutivos da estética neobarroca -, e parodia o Século de Ouro espanhol, é em Hule que identificaremos uma importante torção do ponto de vista estilístico e temático.

${ }^{56} \mathrm{O}$ fato do escritor ter publicado pela Editora Brasiliense o opúsculo O que é a AIDS (19987), torna-se igualmente relevante.
} 
artigo publicado em 1985 por uma importante revista ${ }^{57}$ de cultura e política da época, o antropólogo Néstor Perlongher indigna-se: “Bombardeio de imagens, de discursos que convocam o pânico, a ameaça da AIDS já transcendeu o sofrimento privado das suas vítimas [...], para se converter num dispositivo de moralização que busca reordenar os corpos e suas paixões", ou seja, um dispositivo proibicionista e repressivo, como ele mesmo o afirmava. Ainda no respectivo artigo lemos:

Nessas condições, as estratégias desencadeadas a partir de um problema real - a emergência da AIDS - passam por policiar e organizar as sexualidades perversas, no sentido de diminuir a frequência, a diversidade e a intensidade dos encontros.

Aqueles que estavam "fora" da sociedade são hoje instruídos pelo aparelho médico e paramédico no sentido de disciplinar os poros e as paixões. $O$ tão declamado direito a dispor do próprio corpo vai-se transformando, no final das contas, no dever de regrá-lo. (Idem, grifos nossos).

Em sua antepenúltima antologia, Néstor Perlongher parece absorver "[...] a crueldade do real na palavra", como sublinha Adrian Cangi em "Contos, crônicas, algumas vaidades e uma diatribe", prólogo a Evita vive e outras prosas (2001, pp. 9-19)o que parece ser potencializado principalmente nas duas últimas obras de Néstor Perlongher, como veremos adiante. Assim como Adrian Cangi, constataremos que a potência da palavra perlongheriana “[...]” não existe sem dor, sem dilaceramento" (Idem).

Sobre este aspecto, o período que compreende os anos finais da década de 80 e o início da década seguinte representa um divisor de águas na obra do poeta argentino, e isto não só porque documenta os avanços da sociedade moderna e suas consequências, como sinalizado por Perter Fry (1987, pp. 11-15). Neste mesmo período, vale ressaltar,

\footnotetext{
${ }^{57}$ Fazemos menção ao artigo publicado em Lua nova: Revista de cultura e política, cuja publicação encontra-se disponível na Plataforma Scielo: http://dx.doi.org/10.1590/S0102-64451985000400007. Acesso em novembro de 2018.
} 
além das publicações de $O$ negócio do michê: prostituição viril em São Paulo, O que é AIDS e Hule, Néstor Perlongher ganha uma bolsa de estudos para realizar o doutorado na Europa sob orientação do sociólogo francês Michel Maffesoli - projeto que duraria quatro anos sendo interrompido, porém, em decorrência dos infortúnios, que acometeram a saúde do poeta.

Néstor Perlongher morreu em São Paulo em 1992, vítima de Aids. Antes disso, viajara a Paris, com uma bolsa Guggenheim, sentindo-se despaisado e como que hostilizado na capital francesa. Passou então por uma fase de busca existencial atormentada, que o levou à adesão ao culto do Santo Daime e a experiências místico-alucinatórias, poéticovisionárias. (Folha de S. Paulo, 1 de julho de 2001) ${ }^{58}$.

Segundo Adrian Cangi, “[...] corrían los años 90 y Perlongher escribió: Nueve meses en París, parto extraño, político y polémico [...]" (1999, p. 51). Neste ensaio reflete Néstor Perlongher"59: "En la segunda mitad de 1989, cometí el error (la imprudencia, fascinado como una niña proletaria, por las luces benjaminianas de los pasajes de Lutecia) de aceptar, después de un duro trámite, una beca en París [...]”. Nota-se, deste modo, que o curto período vivido na França resultou num dos relatos mais amargos produzido pelo ensaísta, já que "[...] responde en este ensayo parisino, con indignación e impostura, a la élite intelectual francesa y su postura de ghetto sagrado" (Idem). Evidenciam-se as preocupações pessoais do escritor, as de “[...] de quien se sabe verdaderamente amenazado por la muerte" (GASPARRI, 2013, p. 03): o poeta, doente, morreria pouco

\footnotetext{
58 "Perlongher: o neobarroso transplatino", matéria publicada por Haroldo de Campos no "Caderno +mais", do Jornal Folha de S. Paulo, por ocasião do lançamento de Evita vive e outras prosas (2001). Arquivo disponível em: https://www1.folha.uol.com.br/fsp/mais/fs0107200116.htm. Acesso em outubro de 2018.

${ }^{59}$ Uma versão deste relato aparece em Evita vive e outras prosas (2001), publicada por Iluminuras, com seleção e prólogo de Adrian Cangi e tradução de Josely Vianna Baptista.
} 
tempo depois. Ainda de acordo com Adrian Cangi (1999) em nota introdutória ao relato ${ }^{60}$ : "Los avatares convierten a este texto en un jirón maldito de las experiencias de Perlongher", inclusive, se “[...] podría otorgarle otro título a este artículo: maldiciones sobre París”. (CANGI, 1999, pp. 51-52, on-line).

Outro aspecto, porém, merece ser destacado e relacionado a Hule: o fato de já em "Nueve meses en París" verificar-se o lugar especial atribuído à visão do eu poético perlongheriano, cuja ação observadora passa a ser compreendida como vetor, que dá vazão à tessitura poética. A rua ou o boudoir - o quarto - tornam-se, sobremaneira, os espaços em que estão ambientados seus versos e personagens. Poemas como "Preambulos barrosos", "Trottoir" e "Devenir Marta", por exemplo, aludem ao deambular perseguido por Néstor Perlongher, isto é, referendam o imaginário de circulação desejante em que insiste o poeta em todos seus movimentos de escrita. Num dos paratextos de $O$ negócio do michê: prostituição viril em São Paulo (1987a), lemos:

Centro de São Paulo. Região da Praça da República, Avenida São João e Largo do Arouche. O local dos travestis, prostitutas, malandros e marginais. Ao longo de quase três anos, o antropólogo Néstor Osvaldo Perlongher foi a este universo para investigar a vida e os métodos de sobrevivência dos michês, rapazes geralmente jovens que, sem abdicar da sua masculinidade, prostituem-se para homossexuais maduros. Pesquisou, entrevistou michês, ouviu depoimentos de clientes e homossexuais. Assim, elaborou um estudo completo sobre o circuito da prostituição viril nas ruas de São Paulo.

Nas três obras supracitadas, além do aprofundamento da estética neobarrosa, que figura em Hule, a deriva desejante surge como protagonista: ora o exagero e os abusos

\footnotetext{
${ }^{60}$ Nos referimos à apresentação que consta na revista Hispamérica, no 84, de dezembro de 1999, pp. 5152. Disponível em: https://www.jstor.org/stable/20540155?read-now=1\&seq=1\#page_scan tab contents. Acesso em novembro de 2018.
} 
dos materiais linguísticos contracenam junto à contraversa estética kitsch; ora como assunto "ao menos três vezes maldito": o desejo

[...] transitório e mediado pelo dinheiro; que corre entre as pessoas do mesmo sexo, e que une, momentaneamente, pessoas socialmente distantes (rico e pobre, branco e negro, velho e moço, "feminino" e "másculo"). O desejo que corre na absoluta contramão do desejo socialmente aceitável: aquele que é duradouro e ausente de "interesse", que une pessoas de sexos opostos e socialmente próximas. O desejo que resulta em casamento, procriação, herança e, consequentemente, na reprodução de uma sociedade de classes, segmentos e estamentos, diferenciados e desiguais. (FRY, 1987, pp. 14-15).

Para Peter Fry, os anos de pesquisa em que Néstor Perlongher esteve motivado a analisar as redes que interceptam o desejo, revelam tanto um tratado sobre as margens quanto o apelo de Néstor Perlongher a que formas hegemônicas de regulação do desejo fossem questionadas e compreendidas enquanto dispositivos que encubam as derivas desejantes. É a partir do devir mulher, por exemplo, que estas formas passam a ser ignoradas e seus discursos ameaçados de uma frustração crônica, considerando é claro o cinismo camp contracenado pelas personagens de Néstor Perlongher, como no poema "Devenir Marta":

\title{
"DEVENIR MARTA"
}

\author{
A lacios oropeles enyedrada \\ la toga que flaneando las ligas, las ampula \\ para que flote en el deambuleo la ceniza, impregnando \\ de lanas la atmósfera cerrada y fría del boudoir. \\ A través de los años, esa lívida \\ mujereidad enroscándose, bizca, \\ en laberintos de maquillaje, el velador de los aduares \\ incendiaba al volcarse la arena, vacilar \\ en un trazo que sutil cubriese \\ las hendiduras del revoque \\ y, más abajo, ligas, lilas, revuelo \\ de la mampostería por la presión ceñida y fina que al ajustar \\ los valles microscópicos del tul
}


sofocase las riendas del calambre, irguiendo levemente el pezcuello que tornado mujer se echa al diván. (PERLONGHER, 1997a, p. 139).

"Devenir Marta" - como sugerido no título - engendra o devir-mulher: uma "[...] mujereidad bizca", que destrona a seriedade da "jóia de coque loiro" e "rainha-mãe dos descamisados" ao mesmo tempo que diverge do olhar tosco, "errante y fijo" caricaturizado em "Trottoir": outro poema de Hule, cuja personagem - pestaña de nylon, que circula na chamada "baixa prostituição" (PERLONGHER, 1987a, p. 29) - se lança na ausência de traquejo com el mundo de las modas ao mesmo tempo que "renguea" "el encarnado pie", "los pegasos" ironiza o poeta, que avança e atraca "en la remolina de los pliegues".

Por um lado, a feminilidade de Marta é irrefreável e ensimesmada, revelando-se na saturação de "lacios oropeles", que inflamam "[...] la atmósfera cerrada y fría del boudoir". Por outra parte, "Devenir Marta" referenda o processo de construção das personagens perlongherianas, as artificializações e estratégias reiteradas na arquitetura do devir-feminino, operando como argumento - intercambiável - no processo de composição das personagens perlongherianas. Gabriela Beatriz Moura Ferro (2010) enfatiza que a “conciliação de elementos" utilizados pelo poeta faz mais referência "ao difícil processo de construção do devir-mulher do que ao êxito do seu resultado" (p. 71). Para a autora, a beleza desta mulher: "viria exatamente do jogo artificioso da beleza forjada nos rústicos traços masculinos" (Idem).

Como em Eva Perón, Camila O’Gorman”, "Mme. S”, "Dolly”, como nas “tías solteronas que intercambian los peines grasientos del sobrino" (Idem, p. 82), "Devenir Marta" tutela uma força simbólica inaudita e avessa às leis da natureza, é inatural por 
excelência, nas palavras de Susan Sontag (1964). É, por assim dizer, um “código pessoal”, uma feminilidade camp, solvente da moralidade - aspecto que, analogamente, revela a predileção de Néstor Perlongher pelo artifício e extravagância. A conversibilidade de "homem" e "mulher", enfatiza Susan Sontag, "[...] é a tentativa de fazer algo extraordinário. Mas extraordinário, no sentido, frequentemente, de especial, deslumbrante. (A linha curva, o gesto extravagante.) Não extraordinário simplesmente no sentido de esforço" (Idem).

O gesto extravagante persiste em Hule tanto por meio dos motivos decorativos e curvaturas, que ornamentam os versos de "Formas barrocas" com a voluta e "[...] las regurgitaciones de la piedra jabonosa" tocada "[...] con manos miguelangescas de camionero medieval (PERLONGHER, 1997a, pp. 129-132), quanto através da intimidade insinuativa de poemas como "Látex", "El bretel” ou pela suposta coprologia resgatada em "Salmonella". Nos dois primeiros poemas, as palavras meticulosamente recolhidas pelo leitor e rearmadas - como num diálogo secreto entre este e o poeta -, revelam não só os constantes descentramentos operados na escritura neobarrosa perlongheriana como também expõem as várias alusões às derivas desejantes.

\section{"LATEX"}

En el brilloso látex envainada la turgencia plegando espejos riza los vellos que descuellan para no derramar el ronroneo de la sal-pica-dura.

Sal pica dura!

Porque rasgando el aflojado limo ásperas púrpura iluminas, ciegas emanaciones sulfurosas azulan el banlon calloso de la interioridad, si al trueque de los flujos irriga, viento de hades, el sinuoso 
pachuli de embestida cenagosa, mucílagos

toman la sordidez de los murciélagos, índigas

supuraciones corren el foco de la foto,

tijereteando la película

con la canilla del descarne,

el chorro de ceniza rancia, raso

sobre la losa, rosa pálido. (PERLONGHER, 1997a, p. 133).

\section{"EL BRETEL"}

Cuerpos, marcas de cuerpo en el bretel trenzado, que ata a la baldosa la pirueta de la mirada que circula, azul, el fijo merodeo de los rabos en el fulget del parque oscuro, cuevas curva el bretel, lumina, reconoce en lo blondo de las gasas la ceguera del ánade, guiándolo,

incrusta en la espesura de las pieles un

tornillo de jade, un anteparo

un recaudo barroco sosteniendo a horcajadas el peso

de los muslos

en la blusa. (PERLONGHER, 1997a, p. 135).

O intumescimento do corpo revelado "en el brilloso látex", evidenciando deste modo a turgência do órgão genital "envainad[o]", contrasta com a sensualidade dos corpos e das “[...] marcas de cuerpo en el bretel trenzado [...]" o qual não só “[...] incrusta en la espesura de las pieles [...]" como também deixa em evidência “[...] el peso/ de los muslos/ en la blusa" (Idem, pp. 133-135). Tanto em "Látex" quanto em "El Bretel”, Néstor Perlongher reassume o lugar do antropólogo social, isto é, o olhar de quem observa os corpos no interior de um contexto específico: dos anos 80, da emergência da AIDS também corpus de sua pesquisa -, e não só performatiza o ato sexual como constata os processos de normalização, que atravessam e modificam os fluxos das sexualidades subversivas, sobretudo a homossexual. Sexualidade cujo "[...] fijo merodeo de/ los rabos en el fulget $[\ldots]$ " expõem as miradas que circulam discretamente, sufocadas pela clandestinidade "[...] del parque oscuro" (Idem). Discorrendo sobre o que foi a revolução sexual dos díscolos, em $O$ que é AIDS (1987b) o escritor assinala: "Seja como for, a 
introdução de uma fina película de látex entre os lascivos órgãos pode talvez adquirir, para além do terapêutico, algum valor simbólico - à maneira de uma inscrição que marcasse, no turbilhão dos fluxos, a presença transparente da lei” (pp. 75-76). O que, em distintos contextos; e não somente naquele que é retomado pelo poeta, significa transformar a prevenção em repressão, em decorrência da paranoia generalizada, da espetacularização da mídia e dos "esquemas médico-farmacológicos" que, como assinala Néstor Perlongher recuperando um pronunciamento do pintor Darcy Penteado, “[...] certamente pretendem faturar altíssimo às custas da AIDs [...]” (Idem, pp. 53-54).

"Salmonella", por outro lado, parece fadado a ser lido como um poema-tratado de anatomia humana. Poema cujo argot específico, ademais de explicitar os "giros" do eu poético, isto é, a vulnerabilidade generalizada de um corpo infectado por distintas bactérias ("Salmonella Carinii Pseudomonas"), demonstra também os vários "yiros" de uma tessitura poética bifronte, como ressalta Pablo Gasparini (2010).

\section{"SALMONELLA"}

Salmonella Carinii Pseudomonas:

argot del cuerpo estriado, fístula red, glostora ganglio-

nal en la peineta, nimba que la hoz

candente corpolina, globulillos, sapitos

llagas en la burbuja del jabón, sudor viscoso, detergente, hialinidad del piélago desciende, retamar, jaba que lima, hoz, haba partida, hiel, mucilagosa, micos de rancio jade, mantecoso espiralar, en trucos de pancake: pancake azor fatigas persistentes, sueños truncos, calores indebidos, supuraciones desmayadas, rictus de intempestivo agite: giros mansos disueltos en la letrina, pencas de sulfuro, cortadas en abanico, dragas 


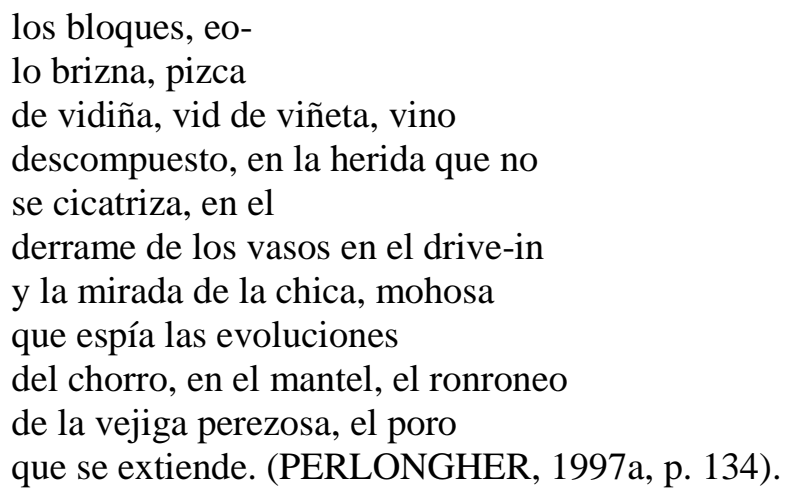

O contexto exibido em "Salmonella", o drive-in, não por acaso, funciona como uma destas formas de dinamitar os sentidos, tendo em vista a turbulência que a maquinária barroca promove no plano da significação. O neobarroso perlongheriano aparece aludido: os yiros já não são outra coisa senão as turbulências da língua, capazes de desintegrar a unidirecionalidade dos sentidos, como saberíamos em Caribe Transplatino (p. 17). A difusividade das substâncias confisca o sentido atribuído à patologia, às "llagas" e aos "giros mansos disueltos/ en la letrina" como "pencas de sulfuro" (Idem, p. 134), já que a "hialinidad del pié/ lago desciende, retamar" e "lima" a joia barroca. Como assinala o eu poético: neste "derrame de los vasos" (ou dos versos?), que resulta em "sudor viscoso", “fatigas persistentes", “calor-/ es indebidos" e "supuraciones", há "una herida que no/ se cicatriza", cuja contaminação parece potencializada, sobretudo, através do "poro/ que se extiende". Esta ferida, por outra parte, não representa a falência dos órgãos de um corpo furiosamente atacado, antes, evidencia a fúria de uma estética que é observada pela mirada "mohosa" "de la chica [...]/ que espía las evoluciones/ del chorro" e "[d] el ronroneo/ [...] que se extiende" nas margens transplatinas. A língua, por extensão, também participa dos yiros do eu poético, é, por assim dizer, uma "diosa puta callejera", lugar de limites difusos, de turbulência e proliferação de múltiplos sentidos. 


\subsection{Aguas aéreas: experiências extraordinárias e alteração do "real"}

Seja no interior da dicção callejera, vagabunda ou ocasional (ROSA, 2002); seja nas geometrias enunciativas intrigantes elaboradas por Néstor Perlongher, identificamos o trabalho com os absurdos da materialidade poética, propondo com isto formas de evadir-se do mundo: "salir de sî", diria o poeta. De acordo com Néstor Perlongher, a poesia deriva da experiência extática, deriva de formas de romper bem como de projetarse em outros mundos possíveis. Os antigos gregos apostavam em quatro formas específicas do transe: mântica, poética, erótica e teléstica, cada qual relacionada a um referente: a Apolo; às Musas; a Eros/Afrodite e a Dionisio, respectivamente. Das quatro, Néstor Perlongher seleciona a segunda: a poética, confirmando que esta tem "algo de oracular" e hermético, algo “[...] dificilmente interpretable o aun intraducible [...]”, e que, apesar de sua particularidade, dado que não passa “[...] por el plano de la comunicación, sino, primeramente, por esta suerte de chispa interior que da la conexión de las almas en trance"; a criação poética

[...] revela su parentesco con otras formas del trance: a comenzar por las heteróclitas formas de ejercicio espiritual capaces de conducir al arrobamiento y la fusión en la delicuescencia celeste, hasta todas las variantes de salida de sí inducidas a través de la ingestión de sustancias psicoactivas [...]”. (1997b, p. 151).

Em Aguas aéreas (1991), Néstor Perlongher logra o diálogo com outras formas de transe, sobretudo se consideramos que o poeta escreveu Aguas aéreas recuperando as experiências vividas durante seu contato com a religião do Santo Daime ${ }^{61}$, cujo ritual tem

\footnotetext{
${ }^{61}$ No artigo "Palabras chorreantes: éxtasis y creación poética en Néstor Perlongher", publicado em 2011 na Revista Forma, Alejandra León Arratia analisa tanto Aguas aéreas quanto El chorreo de las iluminaciones considerando a fase em que Néstor Perlongher aderiu à religião brasileira do Santo Daime. A autora discute em que medida a ingestão de bebidas psicoativas, como no caso da ayahuasca, bem como os estados extáticos reconfiguram e impulsionam novos arranjos da palavra poética. Arratia também
} 
como particularidade a administração de bebida enteógena, conhecida como ayahuasca, hoasca ou iagê. No final de Aguas aéreas, o poeta explicita:

\author{
Estos poemas se inspiran en la experiencia \\ del Santo Daime. Agradezco al Centro Eclético \\ de Fluyente Luz Universal, "Flor de las aguas", \\ de San Pablo, por el privilegio de haberme permitido \\ acceder a la bebida sagrada. (PERLONGHER, 1997a, p. 293).
}

Além da unidade temática assegurada na respectiva antologia, Néstor Perlongher intensifica o grau de proximidade entre palavra e corpo. Os fenômenos recuperados substituem os olhos acostumados do poeta - e do leitor -, como assinala Alejandra León Arratia (2011). O poeta manipula a realidade de modo não ordinário, e as visões não encontram ancoragem no real, como em Austria-Hungría ou Alambres. Sua poesia busca contar o vivido, apresentar-se como reservatório do elemento social, contudo desta vez reconfigurada, amparando-se no desconhecido e inefável. Durante a leitura dos versos perlongherianos nota-se a construção de outras realidades, nas quais não só é impossível rastrear algum tipo de função mimética, como também se percebem protagonizadas por sereias de celofane, por cenários repletos de luzes e fosfenos “[...] que inundan las pupilas $[\ldots]$ ", que causam “[...] temores y placeres $[\ldots]$ ”, e que não só desautomatizam a familiaridade dos sentidos empregados às palavras: "El poeta hace versos que no se entienden [...]" (PERLONGHER, 1997b, p. 149) -, como instauram sensações avassaladoras (ARRATIA, 2011, p. 84): "Ello porque instalan el recurso mágico de su 1997a, p. 293) 
resonancia en otro estado de conciencia, en un estado de conciencia cercano al trance" como pode ser recuperado no ensaio "Poesía y éxtasis"62 (1997b, p. 149).

A poesia de Aguas aéreas se versifica embarcada em hálitos, ânsias, em "pompas irisadas" (1997a, p. 257), traduzem um mundo feérico, engendrado por um "xamã da escritura que chegou a uma nova definição de seu exercício", como refere o poeta uruguaio Roberto Echavarren na introdução a Lamê, publicada pela Editora da Unicamp em 1994. A própria estrutura da obra denota os níveis de tensão experimentados pelo poeta, demonstrando com isto a continuidade dos processos de combinação bem como os efeitos sonoro-semânticos acumulados ao longo do processo de escrita.

Em Aguas aéreas o poeta contribui com a ampliação dos arranjos visuais, cujo cenário de fundo apresenta tanto a atmosfera selvática quanto a pluralidade de elementos que orbitam esta paisagem; e que, posteriormente, atravessam as imagens manifestadas em seus versos, como observado no poema "XXII":

\section{XXII}

Este en selva inconstante pino alado

Conde de Villamediana

ASCESIS FORESTAL: el agua sólo como excusa o cauce para el entroncamiento del tronco en el ramaje, sutileza fluvial, el fluir de la canoa por el divertimiento de las ramas, haciéndole de concha al sibilante estuche, chispas de borravino nacían del encuentro amoroso del codo de la piragua con el nudo del árbol adamado, inclinado a enguantar o feminar sus redes, al otro lado del arroyo, envuelto, vegetales que entraban en el agua, un devenir ácueo del palo,

navegan en el bosque. (1997a, p. 276).

\footnotetext{
62 Vale mencionar que para além de Aguas aéreas, em Prosa plebeya: ensayos (1997) também se coloca em evidência o interesse pessoal de Néstor Perlongher no que se refere aos princípios do culto do Santo Daime. Sobre esta experiência, o poeta e ensaísta escreveu alguns textos, tanto poéticos quanto ensaísticos, entre os quais "La religión de la Ayahuasca" - considerado como um dos mais completos sobre o tema. Outro ensaio igualmente relevante é "Poesia y éxtasis" no qual o ensaísta discute aspectos inerentes ao ritual: "[...] montado en torno a la ingestión de la bebida sagrada, la ayahuasca o yagé, en el que las expediciones visionarias por las infractuosidades transpersonales y los paraísos del más allá, son puntuadas y orientadas por himnos musicales, recibidos por inspiración divina por los correligionarios [...]" (1997b, p. 153).
} 
O cenário é, portanto, menos analítico que contemplativo. Há como uma espécie de degustação de sensações e visões, que se observa atravessando o corpo do poeta e do leitor. Como se nota nos versos precedentes - interligados pela adoção de uma dicção prosaica -, o estilo livre de Néstor Perlongher é retomado nesta antologia. Aqui, entretanto, uma particularidade em relação às demais coletâneas do autor chama-nos a atenção: a escolha de algarismos para nomear os poemas, cujos títulos - aleatoriamente atribuídos - são dados por meio dos vocábulos que figuram no verso inicial de cada estrofe.

Já pelo título, Aguas aéreas, a escolha de Néstor Perlongher não se aplica simplesmente ao uso do oximoro, como sinalizado pela crítica. Isso porque, uma vez considerada a infiltração do culto do Santo Daime bem como o êxtase enquanto estado induzido através da administração de bebida enteógena, a ayahuasca - ambos compreendidos como possibilidades extáticas per se assim como a palavra poética -, o poeta relaciona os termos visando explicitar o sentimento de perda de autocontrole e afastamento parcial das faculdades corporais que o sujeito experimenta. No Evangelho, livro de Coríntios 12: 2-4, esse estado de contemplação é declarado por meio das metaforizações que protagonizam as fusões entre o sagrado e o profano: “[...] Conheço um cristão que há catorze anos foi levado, de repente, até o mais alto céu. Não sei se isso, de fato, aconteceu, ou se ele teve uma visão; somente Deus sabe. Repito: sei que esse homem foi levado, de repente, ao paraíso" (2000, p. 155). "RECIO EL EMBARQUE...”, que aparece no primeiro verso do poema "I", (1997a, p. 247) explica, por meio do intercâmbio intertextual, a natureza abrupta que acomete a entrada ou "embarque", isto é, as alucinações e contrassensos aos quais sucumbe aquele que pratica a ingesta da substância, ou ingressa - de palavra em palavra - nos territórios conglomerados e 
labirínticos da poesia. Para Néstor Perlongher, a ayahuasca simboliza “[...] una suerte de licuefacción de los códigos religiosos" (1997b, p. 161); e por meio das ilogicidades e devaneios que alberga, desperta e ritualiza. Em seu ensaio "La religión de la ayahuasca", Néstor Perlongher explicita as etapas perceptivas:

\begin{abstract}
Vibración de la luz (por momentos parece que las lamparitas del templo estuviesen a punto de estallar), explosión multiforme de colores, cenestesia de la música que todo lo impregna en flujos de partículas iridescentes, que hormiguean trazando arcos de acerado resplandor en el volumen vaporoso del aire, un aire espeso, como cristal delicuescente. La acre regurgitación del líquido sagrado en las vísceras - pesadas, graves, casi grávidas - convierte en un instante el dolor en goce, en éxtasis de goce que se siente como una película de brillo incandescente clavada en la telilla de los órganos o en el aura del alma, purpurina centellante unciendo, a la manera de un celofán untuoso, el cuerpo enfebrecido de emoción. (1997b, pp. 155-156).
\end{abstract}

Em epílogo à primeira edição, Reynaldo Jiménez assinala que a poesia de Aguas aéreas não se ajusta aos: “[...] ojos estrábicos de la razón entendida como razón posesión de alguna verdad que pueda ser enunciada [...]” (1997, p. 362), já que não é nem via de acesso, como também não sinaliza qualquer possibilidade por meio da qual se restabeleça o caos original: "La momentánea expansión que acepta la consciencia es el reflejo de la continua mutación que lo involucra [...] Aquello que evoca es un estado de percepción, desde ya” (Idem).

Outrossim, a fim de compreender a multiplicidade de arranjos sensoriais e visuais que são tecidos nesta obra, bem como demonstrando o rendimento poético assegurado, isto é, a riqueza linguística expressada por meio dos processos morfológicos e sonorosemânticos, duas referências são relevantes: os poemas "I" e "XII", de Aguas aéreas, onde lemos, respectivamente: 
RECIO EL EMBARQUE, airado aedo

riza $u$ ondula noctilucas

iridiscencias enhebrando

en el etereo sulfilar:

un trazo

(deleble persistencia)

en el enroque de los magmas

en el cuadriculado del mantel

-mental, la sala

de entrecasa (arte kitsch)

compostelaba medianías

en el corset del voile, leve y violado.

Pero los voladitos

De los encajes del mantel urdían

Mas que un texto una forma, una figura...

Boreal o suave, sus caireles

no dejaban de iluminar los resbalosos

voleos del minue, por las baldosas: uña

desprendida y procaz, aranando sus pases

el inane, traslúcido volar.

Por espejismos de piel viva

en el tirón de las mucosas

los rasgueos de la uña

elevaban las cántigas

al cielorraso hueco, sublunar.

Recio el cantor, brunidas las guedejas,

dejo de mambo inflige al modular

intensidades en el cieno,

plástica

porosidad de la materia espesa.

En el dejo de un espasmo

contorsionaba los ligámenes

y transmitía a los encajes

la untuosidad del nylon

rayándolos

en una delicada precipitación. (1997a, pp. 247-248). 
XII

- Mi éxtasis... estáteme!...inste ostento

Que no instó en este instante!...tú consistas

En mí, o seas dios que se me añade!...

Martín Adán

\section{INSTÁRONME}

A que empinase el ancho

cálice, no dejase ni una

gota ni una costra

acre.

Nervaduras del cráter craquelé

la visión en el pliegue, la legaña

arañesca, comi

sura lacar

ahora en destellos el

dije hundido en el cáliz

cuarteatdo de pupilas

indecisas

en fuga:

velámenes

brocados, guadamecí

en topacio, incrustación

interna, el borborigmo

tremores lacunares

chata en tílbury

en el

tiborcillo

por

enemas

AGUAS ALUCINADAS

AGUAS AÉREAS

aguas visuales

tacto en el colon húmedo

geyser (o jersey) ístmico

Que ni un dejo. (1997a, pp. 263-264).

Nota-se que em ambos a plasticidade opera como argumento central, cujos versos, ademais da persistência no acúmulo de paisagens "ALUCINADAS" (Idem, p. 247) e 
arranjos visuais caóticos, revelam os detalhes do "embarque" e ingestão da ayahuasca. Hinos e danças compõem o cerimonial em que o aedo esparce notações sonoras que contrastam com os eflúvios amazônicos, com a densidade do ar - igualmente espesso: "ENRARECIDA ATMOSFERA, el incenso/ nebulosa/ [...] roce del sereno/ [...] sus hélices elíseas/ aire al simún [...]" (Poema III, 1997a, p. 251-252). A sinestesia se distende convocando todos os sentidos, impregnando “[...] en flujos de partículas iridescentes, que hormiguean trazando arcos de acerado esplandor en el volumen vaporoso del aire [...]" (PERLONGHER, 1997b, p. 155). A visão "legaña" - que contempla o prodígio da natureza - , se confunde com o “[...] cáliz/ cuarteado de pupilas/ indecisas [...]”. O acrimonioso percebido pelas papilas gustativas após a ingesta do líquido: “[...] INSTÁRONME/ A que empinase el ancho/ cálice, no dejase ni una/ gota ni una costra/ acre" (1997a, p. 263), regurgita nas vísceras do eu do poema, que revela a “[...] incrustación/ interna, el borborigmo/ tremores lacunares/ chata en tílbury/ [...] tacto en el colon húmedo/ geyser (o jersey) ístmico [...]” (Idem). O embarque é passivo, delével ao mesmo tempo que persistente. "Voladitos" e "destellos" - "[...] en una delicada precipitación” (Idem, p. 248) - urdem “[...] los resbalosos voleos del minué, por las baldosas [...]” em “[...] traslúcido volar” (Idem, p. 247). A natureza sublunar modula intensidades - ainda que entrecortadas -, configurando “[...] más que un texto una forma, una figura.../ Boreal o suave [...]" (Idem).

A sensação de instabilidade corporal que acompanha o eu do poema a partir das experiências intensivas que experimenta, pode ser igualmente percebida nos movimentos incorporados ao plano formal dos textos poéticos que compõem Aguas aéreas. Importantes conexões entre o plano da forma e do conteúdo são observadas, revelandose principalmente através dos procedimentos de experimentação linguística. A 
dinamicidade dada ao idioma castelhano - de resto, comum ao estilo do poeta - , surge maiormente cultivada: seja pela exaustão dos elementos morfológicos, que vai brocando e atribuindo novos sentidos aos termos, às vezes, aglutinados ou justapostos; seja através de recursos intertexuais, revelando com isto a ultrapassagem de estilo fixo e ruptura deliberada de estratos que asfixiam a sintaxe do poema, como no caso de "Acrilico" ou “Acre Lirico", poema "VI" de Aguas aéreas, onde lemos:

\begin{abstract}
ACRILICO (ACRE LIRICO) más que esplendor volumen tornaluz luz fría luna acuática su raye (interseción de élitros, choque o ballet de vagalumes, niágara) de guante calza el espesor glaceando el manatí de una cutícula de nubes, cutis níveo, glostora de nivea, en la ampulosidad del ademán glorioso disponíase el zarpe de la raya, cuadriculado en vértigo, craquelé, sin dejar de ser ruina, pegoteado de babas, la rebaba de nácar estirada en el borde de su vaina de vals, ríspido enroque que trastoca los estremecimientos en connubios, leves, alados, casi voiles, manatíes sirenas, bosques río, pues el milagro de su sobresalto, al cascar, en granadas, los aretes de esparto, les despertaba napas de titilante ánade, vacío, vagabundo, su tersura de plumas en el cauce azaroso, no nada, sino que se deja llevar, ser arrastrado, en el remolineo de las hélices por el torrente pantanoso, escándalo de espumas de la orín, agua de porcelana en el chorro de joyas, un portland numinoso al recubrir da vuleta al pulpo como un guante, perla que se revela en goma o nace caucho, dolido por el acre o el acíbar, en lenguas marejadas de un ungüento encantado. (1997a, p. 256).
\end{abstract}

O poema "VI" de Aguas aéreas tem como principal referente a expressão poética em si, a palavra como "ungüento encantado": “[...] más que esplendor volumen tornaluz luz fría luna acuática [...]” (Idem), - aspecto que também se justifica a partir do diálogo intertextual com a canção-poema "Acrilírico", dos compositores Caetano Veloso e Rogério Duprat ${ }^{63}$; ainda que o "motor da saudade" em Caetano Veloso seja o "[...] canto

\footnotetext{
63 “Acrilírico", de 1969, do LP Caetano Veloso, foi composta por Caetano Veloso e Rogério Duprat, pouco antes do exílio londrino vivenciado pelo cantor baiano. Em que pese o estilo tradicional e de vanguarda assegurado na canção, a composição recobre questões muito importantes para a época não só porque integra o movimento Tropicália, como também por ter sido produzida logo após o "ano que não acabou", isto é, 1968: período considerado como "divisor de águas", principalmente por simbolizar uma série de conflitos e mudanças sociais, históricas e políticas ocorridas no país. Para uma leitura aprofundada, ler "Tradição e vanguarda na obra "Acrilírico" de Caetano Veloso e Rogério Duprat", artigo de Rodrigo Marconi,
} 
o ido o tido o dito/ o dado o consumido/ O consumado [...]", as lembranças da "adolescidade", de "um sorriso quieto", que hoje é "amor morto" e "saudade".

O termo "acre" que figura no início da estrofe perlongheriana remete-nos tanto à bebida sacramental quanto aos efeitos ativos e penetrantes circunstanciados pela palavra poética. Por uma parte, as combinações percorridas por Néstor Perlongher insinuam como uma rede, as imagens oferecidas à percepção pela ayahuasca. Por outra, a dissecção dos termos, quase como um anagrama, enfatiza o jogo instaurado com os vocábulos, promovendo, assim, distintos arranjos e recombinações: acrílico/ acrilírico/ acre lírico/ acre/ lírico. Uma palavra, neste caso, é sempre a porta de ingresso em outras, o que também se verifica na canção mencionada, uma vez que, além do título "acrilírico", identificamos neologismos como "colírico" "grandicidade”, "adolescidade”, "telástico", etc.

\author{
Acrilírico $^{64}$ \\ Olhar colírico \\ Lírios plásticos do campo e do contracampo \\ Telástico cinemascope teu sorriso tudo isso \\ Tudo ido e lido e lindo e vindo do vivido \\ Na minha adolescidade \\ Idade de pedra e paz
}

Teu sorriso quieto no meu canto

Ainda canto o ido o tido o dito

$\mathrm{O}$ dado o consumido

$\mathrm{O}$ consumado

Ato

Do amor morto motor da saudade.

publicado em 2012, na Revista Brasileira de Música. Para Rodrigo Marconi, a composição apresenta interessantes intervenções musicais, sobretudo porque sobrevive como "poesia recitada": "[...] livre de uma estrutura melódica e aprisionadora no sentido funcional e harmônico [...]” (MARCONI, 2012, p. 87).

${ }^{64}$ Faixa do LP Caetano Veloso, de 1969. 
Confrontando as duas composições observamos a pluralidade de palavras sonoras selecionadas pelos autores. De início, as derivações prefixais e a composição por aglutinação de termos ${ }^{65}$ como "acre" e "lírico" = "acrílico" em Néstor Perlongher, e “acrilírico" ou "grandicidade" e "colírico" em Caetano Veloso, escondem - pelo menos a princípio - a densidade sugestiva acumulada através das assonâncias e ritmos explorados, que vão sendo revelados verso após verso. Outro aspecto interessante identifica-se através da comutação entre estruturas vocálicas e consonantais no interior dos sintagmas, que oferecem ao texto tanto elasticidade fonética encantadora, como em: "[...] Ainda canto o ido o tido o dito/ O dado o consumido/ O consumado/ Ato/ Do amor morto motor da saudade"; quanto, no caso do poema perlongheriano, ataraxia encaixada nas pausas entre assonâncias e aliterações, revelando, com isto, não somente o estado extático em que se encontra o eu do poema, como também, do ponto de vista formal, uma tensão entre som e silêncio:

[...] el manatí de una cutícula de nubes, cutis níveo, glostora de nivea, en la ampulosidad del ademán glorioso disponíase el zarpe de la raya, cuadriculado en vértigo, craquelé, sin dejar de ser ruina, pegoteado de babas, la rebaba de nácar estirada en el borde de su vaina de vals, ríspido enroque [...]”. (1997a, p. 256).

Nota-se, por fim, que as antinomias apresentadas no poema perlongheriano, bem como na canção-poema de Caetano Veloso, dispensam o utilitarismo da linguagem; antes, aplicam às palavras novas camadas de significação, já que, “[...] desfraldam seus signos em bandeiras buliçosas”, como ressalta Josely Vianna Baptista (s/d). No caso específico do poeta, ratifica a autora: “O senso de ironia é de arrasar: procedimentos de linguagem

\footnotetext{
${ }^{65}$ Aspectos de grande expressividade e que, por meio do diálogo concretista, bem como através de trocadilhos e decomposição de vocábulos, se nota como experimentação formal em Hule, sobretudo no extenso poema "Riga".
} 
são levados a limites apoteóticos, com sua consequente, e inevitável, irrisão. Vocação paródica in extremis. Quedas primordiais, tempestades no Paraíso" ${ }^{\text {"66. }}$

\subsection{El chorreo de las iluminaciones: da contemplação selvática às formas de ingresso interior}

Não é somente em Hule (1989) ou em Aguas aéreas (1991) que a poesia de Néstor Perlongher assume aspectos de ordem mística e espiritual em que se revela o caráter de refinado enlevo de que fala o escritor, tendo em vista que estes mesmos elementos também podem ser verificados em El chorreo de las iluminaciones (1992). Nas primeiras, opera um discurso opalescente; na segunda, apologético. São as reviravoltas entre uma e outra enunciação que, prometidas antecipadamente, inclusive pelos títulos atribuídos às coletâneas, anunciam tanto a contorção quanto o êxtase experimentados pelo corpo do poeta: contorção e êxtase ampliados como experiência no próprio leitor.

"Éxtasis líquido: Néstor Perlongher y la poesía visionaria en latinoamérica" (2012) é, inicialmente, um mapa em que Felipe Cussen determina a diversidade da poesia latino-americana, à qual trata de nomear como visionária. O crítico assinala que, para além das experiências, crenças e referências que o poeta utiliza como estratégias textuais, o tipo de efeito deve ser similar no leitor. Para Felipe Cussen a poesia define-se, então, como "[...] un lenguaje en ebullición, en llamas [...], que bombardea sensorialmente al

\footnotetext{
${ }^{66}$ Os excertos mencionados foram extraídos do artigo "Na tela rútila das pálpebras: olhar sobre a poesia de Néstor Perlongher" (s/d), texto e traduções de Josely Vianna Baptista - uma das principais tradutoras de Néstor Perlongher no Brasil. O texto foi publicado originalmente na página semanal de arte e poesia "Musa paradisíaca", editada pela autora e por Francisco Faria.
} 
lector [...]" produzindo "[...] un mareo místico" (2012, p. 180). O que em "Poesía y éxtasis" pode ser compreendido da seguinte forma: “[...] la palabra poética envuelve en los jubones del misterio una fragancia hermética [...] reverberación intensiva de sones y colores [...] contorsión cortés" (PERLONGHER, 1997b, p. 149).

Néstor Perlongher insiste no poder "oracular" da palavra poética ao que opõe a sobrecodificação desenvolvida pela crítica universitária ${ }^{67}$. Para o escritor, a sobrecodificação do campo poético interdita “[...] la áspera refulgencia del verbo imantado", sua graça lúdica e revelada, e codifica “[...] la radicalidad del misterio oracular en un sentido interpretable y sobre todo traducible a la jerga vernacular del ramo"; domesticando a palavra poética e fazendo prefigurar o estabelecimento de sentidos marcadamente estáveis. Neste sentido, desconfiamos que a "[...] porosidad de la materia espesa [...]” (1997a, p. 178) de seus poemas seja inteiramente capturável. Existe uma fratura na compreensão, que se precipita no irrevelável. De acordo com Néstor Perlongher, sabe-se “[...] que la poesía no es comunicación [...]”. Sua linguagem [...] "abandona" (o relega) su función de comunicación, para desplegarse como pura

\footnotetext{
${ }^{67}$ Neste capítulo do debate perlongheriano é importante deter-nos de modo específico: ao longo de todo o ensaio, Néstor Perlongher insiste no campo da crítica universitária, cujo exercício chama de "sobrecodificação" do campo poético, fazendo uma nítida distinção entre a palavra poética e a expressão sobre a poesia. Para o escritor, os discursos da crítica simbolizam franca oposição às formas de evadir-se e salir de sí, possibilitados tão somente pelo "resplandor y belleza" da qualidade estética. De outro lado, todo o debate parece alicerçar-se em profunda contradição, revelada de modo progressivo nas reflexões apresentadas pelo poeta. No início de seu ensaio, Néstor Perlongher deflagra, portanto, uma rígida desaprovação com a qual termina por explicitar que a poesia guarda em si o êxtase que invade e garante a identidade do poeta, e cujas formas de refinamento são garantidas pelo parentesco com outras formas de salir de sí, ou seja, de entrar em transe - ocasião em que o poeta cita não só o exercício espiritual como também enfatiza a ingestão de substâncias psicoativas, etc. Em certa altura lemos: "La conciencia modificada se caracteriza por un cambio cualitativo de la conciencia ordinaria, de la percepción del tiempo y del espacio, de la imagen del cuerpo y de la identidad personal" (LAPASSADE apud PERLONGHER, 1997b, p. 151), ao que conclui: “¿El poeta? No está. Está del otro lado. Dado vueltas. Es otros” (Idem). Afinal de contas, nos perguntamos, onde está o poeta? Até que ponto o discurso poético e sobre a poesia são tão indistintos quanto afirma Néstor Perlongher? Já que, como sabemos: “[...] lo puro dionisíaco es un veneno, imposible de ser vivido, pues acarrea el aniquilamiento de la vida. Para mantener la lucidez en medio del torbellino, hace falta una forma" (Idem, p. 153).
} 
superficie, espesa e irisada, que "brilla en sí" [...]" (1997b, p. 95), simbolizando uma imensidão de paisagens acústicas, de cores e ideias que perfuram as redes de afetos e sensibilidades do leitor: quem procura decifrar e dar ouvidos aos "[...] límites indecisos de la idea [que] se hunden en las marismas coloridas del susurro, el murmullo, el musitar" (1997b, p. 149, grifos nossos).

Al lado, o de repente, la musiquilla se aproxima y avisa que las huellas se hacen barro en la disolución del filafil, entonces de un tirón se restablece la rigidez de la rodilla (trémula) y el pico de la flor abre en el tímpano la cicatriz de un pámpano

Rajando. (PERLONGHER, 1997a, p. 182).

As imagens rasgadas, "las huellas [que] se hacen barros" (Idem, grifos nossos), a dissolução, com as quais se esbarra a crítica são formas igualmente válidas de abrir “[...] en el tímpano la cicatriz de un pámpano", isto é, são também formas de localizar uma materialidade diferente, que por sua distinção invoca o acúmulo de novos sentidos, bem como fissuras na vertigem causada pela palavra poética.

Assim como em Aguas aéreas, esta espécie de "mareo místico" assinalado por Felipe Cussen (2012) evidencia as visões abstratas que compõem a temática explorada na fase terminal da poética perlongheriana com El chorreo de las iluminaciones - obra postmortem. Felipe Cussen indaga se: "Vale la pena preguntarse, [...] si las palabras, las simples palabras, son capaces de provocar efectos comparables a los de un ritual con drogas o un espectáculo psicodélico", ao que responde consecutivamente:

En el caso de Perlongher, los colores, sonidos, texturas y movimientos van conformando una experiencia sinestésica similar a las recién descritas, y también se buscan efectos soprendentes que aturdan al lector [...]. Pero quizás lo más potente sea el carácter envolvente de este conjunto de textos [...]. La reiteración de ciertos sonidos y ciertas palabras, así como la forma despedazada de un discurso en el que todo 
se mezcla y que no se solidifica un mensaje, una dirección única, van provocando ese efecto de mareo [...]": "mareo místico" (CUSSEN, 2012, p. 184).

Vale mencionar que nesta obra a carência dos limites - que desde o início aparece como uma opção metodológica do escritor -, surge potencializada; agora, o trabalho do poeta consiste em tocar o inefável: "El mecanismo funciona creando una atmosfera sin describirla; la opción estilística del atropello de ideas consecutivas alude a torrentes sensitivos sin descanso [...]" (Idem, 2011, p. 88).

As substâncias enteógenas administradas por Néstor Perlongher insistem no estado alucinatório e contemplativo verificável no próprio poeta, quem contempla a "realidade" como um light show dos anos 60/70, ou como um quadro de Pablo Amaringo, sobre quem inclusive escreve um poema: "El ayahuasquero". Uma espécie de chorreo: uma torrente de imagens altera a visão do poeta (ARRATIA, 2011, p. 84). O poeta emigra do "mundo de las modas" e com isso a impossibilidade de escrita parece cada vez mais iminente, como fica explícito em "Canción de la muerte en bicicleta":

\section{Ahora que me estoy muriendo Ahora que me estoy muriendo}

Lápices que se alzaban nunca más se levantan, duermen el sueño de la tristeza en sábanas de tergopol o mausoleos de mármol donde toda virtud es yacer aterciopelado en el anclaje definitivo de los huesos.

\section{Ahora que me estoy muriendo Ahora que me estoy muriendo}

Ahora, ahora, en este instante digo.

En lo inconstante, en lo inconsciente, en lo fugaz me disemino.

Disperso y fugo [...]. 


\section{Ahora que me estoy muriendo}

Ahora que me estoy muriendo (1997a, pp. 356-359).

Êxtase e angústia passam a ser tratados não só com particular ênfase como também representam duas grandes obsessões na fase terminal do poeta. Nota-se, ainda, que o caráter místico revelado promove o que Alejandra León Arratia (2011) chama de desautomatização das formas de pensar e sentir. De acordo com a autora, ocorre uma fratura na concepção de "real" e "irreal”, posto que a palavra poética não só se solidariza com uma pluralidade de significados - perpassados pelos valores individuais e interpretativos de cada leitor -, como também simboliza “[...] precisiones difusas, donde lo conocido funde lo inhóspito y [...] abarca [...] lo improbable” (ARRATIA, 2011, p. 86). Através da experiência induzida, isto é, por meio da administração de substâncias psicoativas, o poeta entra em contato com uma realidade extraordinária e atemporal, em que convergem passado, presente e futuro, ainda que sua intenção esteja orientada a captar o instante.

Paisagens selváticas e iridescentes contrastam com o sufocamento da restrição do espaço privativo - o boudoir, o quarto. Como numa espécie de aprofundamento das formas de ingresso interior que já constavam na antologia precedente, o poeta para de peregrinar, como assinalado por Tamara Kamenszain. Dos "Infinitos preámbulos líricos [...] pre-ámbulos, deambulos" (1997a, p. 127), de "Preámbulos Borrosos", o poeta de $E l$ chorreo de las iluminaciones: "Desde la fiebre y el sudor neurasténico, fatigando alzadas sábanas tormentosas, levanta los ojos [...]”; e agora, “[...] abajo, en la cama (estanque final) tiene toda su atención poética puesta arriba, en el cielorraso (el cielo es una turbulencia celeste) (KAMENSZAIN, 1997, p. 367). Não é somente a percepção visual 
do poeta que se desloca na emigração do espaço selvático ao privativo apresentado em sua última obra, posto que sua voz também é reconfigurada. Em El chorreo de las iluminaciones descobrimos que às experiências contemplativas do poeta somam-se as "iluminaciones" anunciadas no título, isto é, a multiplicidade de vozes convocadas ao longo da antologia. "Iluminaciones" representadas pelos escritores e artistas aos quais Néstor Perlongher dedica seus poemas, sendo que, ao fazê-lo, convida estas mesmas vozes para seu "aullido de fin de fiesta". Assim como em "Piedra fundamental" de Alejandra Pizarnik (1971), em que anuncia: "No puedo hablar con mi voz sino con mis voces", Néstor Perlongher expressa o desejo profundo de estabelecer correspondências por meio da escrita. Inspirados na leitura que Roberto Machado apresenta sobre Friedrich Nietzsche, observamos que na última obra de Néstor Perlongher predomina: “[...] una total reconciliación del hombre con [...] otros hombres" (MACHADO apud, PERLONGHER, 1997b, p. 153); o que de acordo com o poeta pode ser compreendido como a tentativa de destruição da individualidade, isto é: “[...] la ruptura con el principio de individuación y la fusión de las individualidades en un sentimiento místico de unidad con el cosmos, con la naturaleza, con los otros hombres [...]. (1997b, p. 165), isto é, um profundo sentimento de composição. Para Felipe Cussen (p. 05): “[...] la palabra está más para invocar fuerzas [...] y remitir energías que para nombrar específicamente”.

Em El chorreo de las iluminaciones a primeira grande obsessão do poeta: o amontoamento de materiais, isto é, o kitsch, "el mundo de las modas" - com suas opalescências e variações, "terciopelo", "lamé”, “carmesí”, "pingo”, "rímmel”, “bombachas de nylon", "breteles”, “saquitos de banlon”, "ligas”, “carteras”, “espartillos”, “hebillas”, echarpe, “rodete”, “estampados de Gobel”, etc. -, revelam uma mutação: “el inmanente aullido" do poeta. Em “Decepción” (1997a, pp. 347-348), o cisne de “[...] alas 
manchadas, interroga la estela [...]/ en el estanque final/ finge piruetas/ caracole[a] a la deriva/ [...] como un frenesí negativo"68. Na poética terminal de Néstor Perlongher - já consciente de el mal de sí -, "la loca plañe porque va a morir [...]" (Idem, p. 341). "El mal de sí”, que inclusive foi um dos últimos poemas de Néstor Perlongher, surge com um apelo pungente: "Detente muerte"

Detente muerte:

tu infernal chorreado

escampar hace las estanterías,

la purulenta salvia los baldíos

de cremoso torpor tiñe y derrite, ausentando los cuerpos en los campos:

los cuerpos carcomidos en los campos barridos por la lepra

Ya no se puede disertar

Ve, muerte, a ti.

Enconchate sin disparar el estallido de la cápsula.

Escondida que no seas descubierta.

Pues una vez presente todo lo vuelves ausencia.

Ausencia gris, ausencia chata, ausencia dolorosa del que falta.

No es lo que falta, es lo que sobra, lo que no duele.

Aquello que excede la austeridad taimada de las cosas

o que desborda desdoblando la mezquinidad del alma prisionera.

Mientras estamos dentro de nosotros duele el alma,

duele estarse sin palabras suspendido en la higuera

como un noctámbulo extraviado (Idem, p. 355, grifos nossos).

Como observado, mais uma vez a morte aparece como personagem central na poética perlongheriana: "Detente muerte", suplica o eu do poema. Por meio deste processo de personificação, observamos que o poeta: “[...] comunica la representación de la realidad exterior que se forma en la pupila de [su] personaje [...]” (BOUSOÑO, 1966, apud SILVA, 1989, p. 154). Por um lado, para o eu poético, a morte figura tanto como alegoria

\footnotetext{
68 "Cisne de alas manchadas", em alusão ao poema modernista "Nocturno", de Delmira Augustini, publicado em Los cálices vacíos (1913): "[...] Yo soy el cisne errante de los sangrientos/ rastros/ voy manchando los lagos y remontando el/ vuelo".
} 
da infecundidade, já que “[...] una vez presente todo lo vuelves ausencia”; como também acampa e ausenta os corpos, já “[...] carcomidos en los campos, barridos por la lepra”. Para o poeta "ya no se puede disertar", simbolizando, ainda, a impossibilidade da escrita:

Mientras estamos dentro de nosotros duele el alma, duele ese estarse sin palabras suspendido [...] como un noctámbulo extraviado. (Idem, p. 355).

$\mathrm{Na}$ angústia do quarto, cuja mirada insistente só prova que "el techo es una turbulencia celeste", em que se arrasta a mirada e a alma do poeta "por los agujeros de la respiración" (p. 348), o poeta sabe que está morrendo, e diz: "Adiós jeringas, tubos que conducen bilis, sangre, suero, aductores $[\ldots] /$ tusadas toses $[\ldots] /$ gemidos $[\ldots] /$ putrefaciones [...]" (Idem, pp. 348-349).

Na poesia de Néstor Perlongher, confirmamos, os que “cantam” são donos de uma voz terminal, são aedos de Thánatos: Eva Perón, os mais de trinta mil cadáveres da nação, o próprio poeta. Como uma espécie de tumor maligno que mutila e consome o corpo paulatinamente, entre mortos e desaparecidos: "las manchas, los zarpullidos del sarcoma/ mueven en la soberana oscuridad", revelando com isso a litania que aparece em "Canción de la muerte en bicicleta": "Ahora que me estoy muriendo/ [...] La sofocación alza del cielorraso relámpagos enanos/ que se dispersan en la noche definitiva e impasible" (Idem, p. 357, grifos nossos).

Além destes aspectos, outras importantes camadas de significação são identificadas no desenvolvimento da estrutura formal dos poemas. Em muitos casos, a 
condição engendradora dos versos e rimas internas - como as aliterações -, em que predominava o estilo livre e isento de enquadramentos, cede lugar a formas fixas da expressão poética. Em poemas como "Tema del cisne hundido (1) e (2)”, "Morenez (2) - un brillo de fraude y neón" y "Luz oscura - recio martirio sabroso", por exemplo, a predominância de quartetos e tercetos revelam aspectos singulares, que realocam a escrita do poeta.

No que se refere às variações do estilo, "Luz oscura - 'recio martirio sabroso"”, por exemplo, funciona como um importante modelo de conivência poética, tanto formal quanto temática, no que corresponde à certa tradição, isto é, à forma clássica do soneto. A exploração do gênero é evidenciada não somente por meio dos quartetos e tercetos que figuram nas três primeiras estrofes do poema com uma métrica irregularmente hendecassílaba, como também por meio de outros recursos formais e referenciais: tanto o oximoro posto no título: "Luz Oscura ...", quanto a dedicatória que o escritor apresenta a Santa Teresa de Jesus.

\section{"LUZ OSCURA"}

"recio martirio sabroso"

Santa Teresa de Jesús

Si atravesado por la zarza el pecho arder a lo que ya encendido ardía hace, el dolor en goce transfigura, fría la carne mas el alma ardida,

en el blanco del ojo el ojo frío cual nieve en valle tórrido: el deseo divino se echa sobre lanzas ígneas y muerde el ojo en blanco el labio henchido.

Funambulesca beatitud la suya, de claroscuros, que al soltar el pliegue de luz inunda el esplandor febeo:

"No es resplandor que nos deslumbra, sino una blancura suave y el resplandor difuso 
que alto deleite da la vista y no

la cansa, ni la claridad que se ve para ver

esta hermosura tan divina". (1997a, p. 304).

Além disso, verifica-se que determinados elementos redirecionam o leitor aos maniqueísmos de uma perspectiva teocêntrica do mundo, fundamentada nos embates entre corpo e alma. Já na primeira estrofe do poema construções como "El pecho... atravesado", "el dolor" y "la carne fría" contrastam com um estado de combustão em que "[...] el alma ardida" e "encendida" se inflama. As distrações mundanas que afastam a alma de algum estado de ascese parece ser uma discussão retomada pelo poeta. A persistência daquilo que é concebido como natural - ou seja, a alma e o estado contemplativo, por exemplo -, versus o artificial transiente - isto é, o corpo propriamente dito, bem como as experiências do mundo exterior e convulsivo -, revelam-se como temas sobre os quais retorna Néstor Perlongher, considerando que em Aguas aéreas algumas questões tinham sido objeto de sua poética. Neste "recio martirio" é possível também sentir não o sabor acre de um "pecho" penetrado "por la zarza", mas sim o de uma alma que transfigura a dor em gozo, em transcendência. Uma conexão mística com o divino inunda a alma, para a qual "[...] el deseo/ divino se echa sobre lanzas ígneas [...]" e cujo "[...] alto deleite da a la vista [...]/ esta hermosura tan divina", tal como a "[...] blancura suave y el resplandor difuso [...] de um “[...] valle tórrido[...]” (1997a, p. 304).

As antíteses que prefiguram no poema, encerrado com as aspas da última estrofe, parecem confirmar que há não só dedicatória como também intertexto com a obra de Santa Teresa de Jesus: "No es resplandor que nos deslumbra, sino/ una blancura suave y el resplandor difuso/ que alto deleite da la vista y no/ la cansa, ni la claridad que se ve 
para ver/ esta hermosura tan divina”. (1997a, p. 304). De acordo com Alejandra León

Arratia (2011, p. 95):

\begin{abstract}
A juzgar por la tipografía y el uso de comillas, sospechamos que la última estrofa corresponde a una cita no especificada. ¿A quién pertenecen estos versos? El tono, palabras y contenido, junto a la previa mención a Santa Teresa en el epígrafe, advierten su autoría; y los versos, tal como indica Ben Bollig, efectivamente son de Santa Teresa de Jesús. Perlongher transforma entonces la prosa de la poeta en versos libres, rematando con ello lo que aparece en un principio como soneto clásico. Trabajados junto al epígrafe de la misma y el guiño "Funambulesca beatitud la suya", el poema conmuta la actitud sobre lo místico que hasta entonces Perlongher muestra. Ben Bollig comenta al respecto un propósito del poeta que instruye la experiencia desde una nueva perspectiva, enfocada básicamente desde y para la corporalidad, tal como se avista en los versos "Si atravesado por la zarza el pecho" o "en el blanco del ojo frío". En contraposición, el corpus poético se ordena simulando un soneto cortado que conjunta, con los términos y orden presentados, el estilo y contenido de Santa Teresa. Una fusión temática cuya funcionalidad, el propósito místico, converge en objetivo: el poeta alude a Santa Teresa de Jesús evocando una tradición del siglo XVI, donde la poeta cristiana explota las posibilidades expresivas para comunicar su conexión mística con Dios. El éxtasis que perfila Santa Teresa apunta a la necesidad expresiva de Perlongher, entendiendo su mención en complicidad poética y temática.
\end{abstract}

Como assinalado, o que em princípio desponta como forma clássica do soneto transfigura-se nos versos livres da última estrofe. De modo que, os desdobramentos formais e a diversidade de temas apresentados em El chorreo de las iluminaciones contrastam com as duas obras anteriormente aludidas, ao mesmo tempo que intensificam o estilo entrecortado e não convencional que resiste: versos enfileirados sem interrupção, frases curtas, decomposição do verso, infiltração prosaica, técnica reiterativa, hipérbatos, enumeração, ruptura deliberada do paralelismo, isto é, uma ampla heterogeneidade de estratos que seguem confirmando a predileção do escritor pela autonomia formal e instabilidade do texto poético, isto é, pela “[...] violação do código da 
linguagem" (COHEN, 1974, p. 40) - resultando num tipo de rendimento poético sempre perseguido por ele. 


\section{CONSIDERAÇÕES FINAIS}

Em “Templar”, Reynaldo Jiménez discute a impossibilidade de que alguma verdade possa ser enunciada pelos "olhos estrábicos da razão", sobretudo quando se considera a instabilidade que antecipa a aproximação à poética perlongheriana (PERLONGHER, 1997b, p. 362, tradução nossa). Paula Siganevich defende a máxima de que: “Aquí todos somos de otra parte, todos pertenecemos a otra lengua, todos somos extranjeros [...]" (2002, p. 13). O também argentino Nicolás Rosa parece concordar com sua conterrânea, já que para o crítico, “[...] la poesía está más allá del lector”, sendo que a inacessibilidade que dificulta a compreensão da tessitura poética parece vincular-se à profusão de temas, subtemas e microtemas em que insiste o poeta. Estes, além de muitas vezes contrapostos, alcançam “[...] un desvarío de las palabras poéticas”. Se o caos passa a ser entendido como uma ordem por decifrar - como assinalou José Saramago retomando o Livro dos contrários -, a poesia perlongheriana está fadada a violentar as formas estáveis de significação, operando sempre pelas bordas, pelo lado de fora, entre a porta de entrada e o desejo desterritorializante: "Perlongher tenía una lengua preparada para su exterminio [...] Trastornar la lengua es el designio de esta poesía”, assinala Nicolás Rosa (2002, p. 40).

Contudo, os movimentos propostos nesta tese excedem o perímetro da materialidade poética, sobretudo porque nossas incursões revelam, por outro lado, o território produtivo e fértil composto pelos textos em prosa, ensaios e, até mesmo, acadêmicos. Em cada um dos textos analisados foram verificadas constantes tentativas de trangressão à leitura hegemônica sempre atribuída à poesia perlongheriana, pelo menos ao longo das duas últimas décadas. Nesta tese defendemos que os gêneros desenvolvidos 
por Néstor Perlongher não podem ser reduzidos uns aos outros, tendo em vista que, articulados, representam a convergência de debates altamente produtivos. Como assinala Malena Rey, no diálogo entre os gêneros “[...] se revelan las señas más emblemáticas de su estilo (la palabra exuberante, el humor desenfadado, la ridicularización de los lugares comunes, la provocación desbocada, el posicionamiento político)"69. Neste sentido, restringir a escrita perlongheriana a categorias taxonômicas não parece ser uma solução plausível, principalmente porque este procedimento obscureceria os distintos movimentos mapeados pelo autor.

Em seus textos Néstor Perlongher estabeleceu tanto uma memória textual legitimida pelas minorias marginais, como reuniu os herdeiros bastardos da nação. Suas personagens - "pérolas berrucas $[\ldots]$ boquitas repintadas [...]"70 - desmantelam a ideia de pátria não só porque desintegram o tom oficial e elegíaco em favor da emancipação política dos corpos e da língua, como também porque revelam distintas cartografias e paisagens culturais: cubanas, transplatinas, brasileiras, etc.

Os territórios, por seu turno, como assinalado no primeiro capítulo desta tese, são planícies repletas de depressões, são espaços incapturáveis e, em certo sentido, inomináveis: toda alusão a um território é simbólica, sobretudo porque o lugar nomeado é sempre a possibilidade de um novo espaço: a deformação geográfica é, portanto, uma

\footnotetext{
${ }^{69}$ Menção ao artigo “'Prosa plebeya' de Néstor Perlongher”, de Malena Rey, publicado em Inrockuptibles, em outubro de 2013. Disponível em: https://losinrocks.com/prosa-plebeya-de-n\%C3\%A9stor-perlongher$13 \mathrm{~b} 86 \mathrm{f} 306 \mathrm{bc} 2$.

${ }^{70}$ Em referência ao poema "Neobarroso: in memoriam" (1993), que o concretista Haroldo de Campo dedica a Néstor Perlongher, por ocasião do lançamento de Evita vive e outras prosas (Iluminuras, 2001).
} 
das estratégias desta escrita. O leitor - não poderia ser diferente: fica à deriva nestes textos, entre o desejo territorializante e a instabilidade toponímica.

Por outra parte, os processos de insubmissão aparecem coagulados em torno a um denominador comum: a corporalidade, a qual reposicionando o protagonismo do corpo opera não só como eixo que orienta o processo de interpretação deste trabalho, como se revela com base no tríptico:

Violência: $O$ cadáver simboliza as formas de violência exercidas pelo Estado, a fim de ressignificar o hiato não preenchido pela história oficial. O poema surge como território de elocução por excelência, cujo eu poético convoca distintas vozes para seu aullido de fin de fiesta, como diria Tamara Kamenszain. Néstor Perlongher dessacraliza a morte, principalmente porque, como sinalizado por um importante protagonista do escritor chileno Roberto Bolaño, da verdadeira violência nenhuma corporalidade pode escapar, ao menos não as nascidas na América Latina. Sob um suposto mundo em ruínas e em decomposição, a corporalidade cadavérica assume a plenitude alegórica: o poeta faz versos agônicos e explicita, com isso, as zonas de indeterminação, isto é, os espaços de contiguidade entre a vida e a morte. Nos poemas analisados o autor arma um sistema de referências históricas (GASPARRI, 2012, p. 30), que - menos que fazer com que o leitor proceda à contemplação do cadáver, do abjeto -, deprava ao mesmo tempo que provoca o espessamento da história. Revela-se a hegemonia e a violência do Estado, evidencia-se o estado de exceção e, como estratégia, o aedo de thánatos intenta subverter a ordem instaurada. Ele não apresenta um mundo em ruínas, porque o próprio mundo deflagra sua autodestruição. 
Desejo: A corporalidade desejante, assim como a cadavérica, também retoma a violência do Estado. Nesta, entretanto, coloca-se em jogo as constantes blitz contra o desejo homossexual. Néstor Perlongher explicita os mecanismos de funcionamento dos dispositivos do poder: uma rede perversa que investe em microoperações de política sexual. A “operação do desejo" expressa, principalmente, o horror e repúdio às liberdades sexuais, isto é, às contorções do prazer. Como assinalado por Néstor Perlongher, o disciplinamento aterroriza principalmente o desejo homossexual por meio de discursos perversos e moralistas. A malha de preconceitos se urde de modo tão contumaz que, nos anos 80, o discurso de "prevenção" da AIDS é usado como estratégia de encarceramento da vida, de modo que a suposta prevenção convertia-se em repressão aos gays. Em todos os casos, nota-se que as corporalidades desejantes aparecem inscritas nas barras da lei: “[...] los cuerpos tienen un único enemigo de múltiples formas: los dispositivos de moralización y normalización de las uniones sexuales" (CANGI, 2000a, p. 69). Como no caso de Antônio Chrysóstomo, verifica-se o julgamento de um preconceito e diferentes tentativas de confinamento do desejo homossexual: a prisão, a imposição de determinadas geografias urbanas, os discursos médicos e a espetacularização midiática. Neste sentido, a estratégia de Néstor Perlongher consiste em fragilizar os limites estipulados aos corpos, de modo que sugere que: "Seria preciso, talvez, conceber uma política sexual diferente que não desconhecesse a multiplicidade dos desejos eróticos nem tentasse disciplinar pedagogicamente [...] os prazeres" (1987b, p. 91). O autor insiste em uma política del goce e, especialmente, na revolução sexual como um ato de amor.

Êxtase: Por fim, a fase extática, a contrapelo dos capítulos anteriores, revela a alteração dos territórios e dos inúmeros trânsitos empreendidos pelo escritor ao longo de sua carreira. Revela também o estado de transe que experimenta o poeta. Néstor Perlongher 
agradece ao "Centro Eclético de Fluyente Luz Universal, 'Flor de las Aguas"” e participa do culto ao Santo Daime. Os limites entre realidade e ficção são cada vez mais tênues, pois o poeta sabe que está morrendo e experimenta no corpo os estragos da enfermidade. $\mathrm{Na}$ fase "terminal" da escrita perlongheriana o corpo líquido do poeta e do poema se formalizam: da forma livre e entrecortada -característica das primeiras obras do autor-, marcada pela decomposição do verso, pela cacofonia reiterada e pelas palavras que “[...] pierden empaque y definición" (ECHAVARREN, 1997, p. 11) chegamos às aproximações à forma clássica do soneto; e, por fim, às formas de ingresso interior, em que predomina o misticismo característico das últimas antologias. Nesta ocasião, o “[...] cisne de alas manchadas $[. .$.$] ", se percebe capturado pela enfermidade, logo, pela$ impossibilidade de seguir escrevendo. Cessam as cartografias corporais em trânsito: de um corpo errático, instável e em constante trottoir nos deparamos com o boudoir do poeta, de onde, consternado, observa: “[...] la noche definitiva e impasible” (1997a, p. 359). 


\section{REFERÊNCIAS BIBLIOGRÁFICAS}

ABREU, Caio Fernando. Pequenas epifanias. $4^{\mathrm{a}}$ ed. Rio de Janeiro: Nova Fronteira, 2014.

ADORNO, Theodor. Dialética Negativa. Tradução de Marco Antonio Casanova. Rio de Janeiro: Jorge Zahar Ed., 2009.

ADORNO, Theodor W. “O ensaio como forma”. In.: Notas de literatura I. $2^{\mathrm{a}}$ ed. Trad. e apresentação de Jorge M. B. de Almeida. São Paulo: Duas Cidades; Editora 34, 2012. (Coleção Espírito Crítico).

AGAMBEN, Giorgio. Estado de exceção. Trad. De Iraci D. Poleti. São Paulo: Boitempo, 2004. (Estado de Sítio).

ALCOBA, Laura. La casa de los conejos. 1. ed. Buenos Aires: Edhasa, 2009.

ALCOBA, Laura. Manèges: petite histoire argentine. Paris: Gallimard, 2007.

ANDRADE, Carlos Drummond de. A rosa do povo. Rio de Janeiro: José Olympio, 1945, p. 10 .

ARGAN, Giulio Carlo. Arte moderna: do iluminismo aos movimentos contemporâneos.São Paulo: Companhia das Letras, 1992.

ARRATIA, Alejandra. "Palabras chorreantes: éxtasis y creación poética en Néstor Perlongher". In. Revista Forma, v. 3, primavera 2011. Disponível em: 
https://www.upf.edu/forma/_pdf/vol03/forma_vol03_09leon.pdf. Acesso em abril de 2016.

ASMANN, Selvino José; NUNES, Nei Antonio. "Michel Foucault e a genealogia como crítica do presente", Revista Internacional Interdisciplinar Interthesis, v.4, $\mathrm{n}^{\circ} 1$, Florianópolis, jan./jun. $2007 . \quad$ Disponível em: http://periódicos.ufsc.br/index.php/interthesis/article/view/889. Acesso em dezembro de 2018.

BAPTISTA, Josely Vianna. "O jade ofegante da página”. In.: Evita vive e outras prosas. São Paulo: Iluminuras, 2001, pp. 115-120.

BARTHES, Roland. O óbvio e o obtuso: ensaios críticos III. Rio de Janeiro: Nova Fronteira, 1990.

BARTHES, Roland. A câmara clara: notas sobre fotografia. Trad. de Manuela Torres. Portugal: Edições 70, 2013.

BAUDELAIRE, Charles. O pintor da vida moderna. Lisboa: Vega Passagens, 1993.

BAUMAN, Zygmunt. Modernidade e ambivalência. Trad. Marcus Penchel. Rio de Janeiro: Jorge Zahar Editor, 1999.

BHABHA, Homi. "De margens e minorias". In: O local da cultura. Belo Horizonte: Editora da UFMG, 2003, pp. 214-222.

BIBLIA SAGRADA: Nova tradução na linguagem de hoje. São Paulo: Sociedade Bíblica do Brasil, 2000. 
BLANCHOT, Maurice. O espaço literário. Rio de Janeiro: Rocco, 2011.

BOLAÑO, Roberto. Putas asesinas. Barcelona: Editorial Anagrama, 2001.

BOSI, Alfredo. O ser e o tempo da poesia. $8^{\text {a }}$ ed. São Paulo: Companhia das Letras, 2009.

BOUSOÑO, Carlos. Teoría de la expresión poética. $4^{\mathrm{a}}$ ed. Madrid: Gredos, 1966.

BUTLER, Judith. Problemas de gênero: Feminismo e subvserão da identidade. Trad. Renato Aguiar. Rio de Janeiro: Civilização Brasileira, 2003.

CANDIDO. Antonio. O estudo analítico do poema. São Paulo: Humanitas Publicações, FFLCH/USP, 1996.

CANGI, Adrian; SIGANEVICH, Paula (eds.). Lúmpenes Peregrinaciones: ensayos sobre Néstor Perlongher. Rosario: Beatriz Viterbo, 1996.

CANGI, Adrian. "Nueve meses en París: presentación”. In.: Hispamérica, ano 28, nº 84, diciembre $1999, \quad$ pp. 51-52. Disponível em: https://www.jstor.org/stable/20540156?seq=1\#metadata_info_tab_contents. Acesso em agosto de 2018.

CANGI, Adrian. Insumisión y subjetividad en la obra ensayístico poética de Néstor Perlongher: Interferencias entre Brasil y Argentina en los años 80. Tese (Doutorado em Letras). Universidade de São Paulo, Faculdade de Filosofia, Letras e Ciências Humanas, São Paulo, 2000a.

CANGI, Adrian. "Una poética bastarda”. Tsé Tsé, n. 7/8. Buenos Aires, 2000b. 
CANGI, Adrian. "Contos, crônicas, algunas verdades e uma diatribe". In.: PERLONGHER, Néstor. Evita vive e outras prosas. São Paulo: Iluminuras, 2001, pp. 919.

CANGI, Adrián. "Poder decir sin descifrar". In. La Habana Elegante - Dossier "Cosa de locas: homenaje a Néstor Perlongher, $\mathrm{n}^{\circ}$ 53, primavera - verano, 2013. Disponível em: http://www.habanaelegante.com/Spring_Summer_2013/March_2013.html. Acesso em julho de 2016.

CARNEIRO, Maria Luiza Tucci. "Holocausto: verdade, memória e negacionismo". In. XXV Jornada Interdisciplinar sobre o Ensino da História do Holocausto em Defesa da Democracia e Cidadania. São Paulo, julho de 2013.

CAVALCANTE, Ania. “Do processo de desumanização à 'Solução Final' (1933-1945)”. In. XXV Jornada Interdisciplinar sobre o Ensino da História do Holocausto em Defesa da Democracia e Cidadania. São Paulo, julho de 2013.

CAVARERO, Adriana. Vozes plurais: filosofia da expressão vocal. Trad. De Flavio Terrigno Barbeitas. Belo Horizonte: Editora UFMG, 2011.

COSTA, Everaldo Batista da. "Paisagem-memória e função social da fotografia". In. STEINKE, Valdir Adilson; REIS JUNIOR, Dante Flávio; COSTA, Everaldo Batista da. (orgs.). Geografia e fotografia: apontamentos teóricos e metodológicos. Brasília: Editora da UNB, 2015.

CRHYSÓSTOMO, Antônio. Caso Chrysóstomo: o julgamento de um preconceito. Rio de Janeiro: Editora Codecri, 1983. 
CUNHA, Anderson Santana. "Finitude Humana: a perplexidade do homem diante da morte". In. V Encontro de Pesquisa na Graduação em Filosifia da UNESP, vol. 3, n 1 , 2010, pp. 183-194.

CUSSEN, Felipe. "Éxtasis líquido: Néstor Perlongher y la poesía visionaria en Latinoamérica”. In. Revista de Crítica Literaria Latinoamericana, ano 38, nº 76, (2012), pp. 173-190. Disponível em: https://as.tufts.edu/romancestudies/rcll/pdfs/76/173-190Cussen.pdf. Acesso em julho de 2016.

DANIEL, Herbert. "Chave de cadeia". In: CRHYSÓSTOMO, Antônio. Caso Chrysóstomo: o julgamento de um preconceito. Rio de Janeiro: Editora Codecri, 1983, pp. 9-14.

DELEUZE, Gilles. "Post-scriptum sobre as sociedades de controle". In.: Conversações

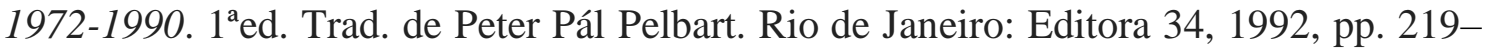
226).

DELEUZE, Gilles. "La littérature et la vie”. In.: Critique et Clinique. Paris: Les Éditions de Minuit, 1993, pp. 11-17.

DELEUZE, Gilles. "Post-scriptum sobre as sociedades de controle". In.: Conversações 1972-1990. Trad. de Peter Pál Pelbart. Rio de Janeiro: Editora 34, 2000.

DELEUZE, Gilles, GUATTARI, Felix. O anti-Édipo: Capitalismo y esquizofrenia 1. Trad. de Luiz B. L. Orlandi. São Paulo: Editora 34, 2011 a.

DELEUZE, Gilles; GUATTARI, Felix. Milles plateaux. Paris: Minuit, 1980. 
DELEUZE, Gilles; GUATTARI, Felix. Mil platôs: capitalismo e esquizofrenia $2.2^{\mathrm{a}}$ ed, vol. 1. Trad. de Aurélio Guerra Neto, Ana Lúcia de Oliveira e Célia Pinto Costa. São Paulo: Editora 34, $2011 b$.

DELEUZE, Gilles; GUATTARI, Felix. Mil platôs: capitalismo e esquizofrenia 2. $2^{\mathrm{a}}$ ed, vol. 2. Trad. de Ana Lúcia de Oliveira e Lúcia Cláudia Leão. São Paulo: Editora 34, 1995.

DELEUZE, Gilles; GUATTARI, Felix. Mil platôs: capitalismo e esquizofrenia 2. $2^{\mathrm{a}}$ ed, vol. 3. Trad. de Aurélio Guerra Neto, Ana Lúcia de Oliveira, Lúcia Cláudia Leão e Suely Rolnik. São Paulo: Editora 34, 2012a.

DELEUZE, Gilles; GUATTARI, Felix. Mil platôs: capitalismo e esquizofrenia 2. $2^{\mathrm{a}}$ ed, vol. 4. Trad. de Suely Rolnik. São Paulo: Editora 34, $2012 b$.

DELEUZE, Gilles; GUATTARI, Felix. Mil platôs: capitalismo e esquizofrenia 2. $2^{\mathrm{a}}$ ed, vol. 5. Trad. de Peter Pál Pelbart e Janice Caiafa. São Paulo: Editora 34, 2012c.

DELEUZE, Gilles. “O anti-Édipo e outras reflexões (1980) - aula de Gilles Deleuze”. In: Trechos selecionados da aula "anti-Édipo e outras reflexões". Fractal: Revista de Psicologia, v. 28, n. 1, pp. 160-169, jan-abr, 2016.

DIDI-HUBERMAN, Georges. Cuando las imágenes tocan lo real. Disponível em: https://www.macba.cat/uploads/20080408/Georges_Didi_Huberman_Cuando_las_imag enes_tocan_lo_real.pdf. Acesso em julho de 2015.

DIDI-HUBERMAN, Georges. La imagen supervivente: Historia del arte y tempo de los fantasmas según Aby Warburg. Traducción Juan Calatrava. Madrid: Abada Editores, 2009. 
DRUCAROFF, Elsa. “Los hijos de Osvaldo Lamborghini”. JITRIK, Noé. Atípicos en la literatura latinoamericana. Buenos Aires: Universidad de Buenos Aires, 1997 (pp. 145154).

DUVIGNAUD, Jean. "Esquisse sur le nômade". In: Espace et societés, n 10/18, Paris, 1975.

ECHAVARREN, Roberto. "Prólogo". In: PERLONGHER, Néstor. Poemas completos (1980-1992). Buenos Aires: Seix Barral, 1997.

ECHAVARREN, Roberto. "A ousadia dos fluxos". In.: PERLONGHER, Néstor. Evita vive e outras prosas. São Paulo: Iluminuras, 2001, pp. 109-114.

ENTLER, Roberto. "Para reler A câmara clara". In.: FACOM, nº 16, 2 sem. 2006, pp. 49. Disponível em: http://www.faap.br/revista_faap/revista_facom/facom_16/ronaldo.pdf. Acesso em abril de 2018.

EPPS, Brad. "La ética de la promiscuidad: reflexiones en torno a Néstor Perlongher". In. Iberoamericana, v. 5, no 18, 2005, pp. 145-162. Disponível em: https://journals.iai.spkberlin.de/index.php/iberoamericana/article/view/996. Acesso em junho de 2016.

ESPÓSITO, Roberto. Bíos. Biopolitica y filosofía. Trad. De Carlo R. Molinari Marotto. Buenos Aires: Amorrortu, 2006. (Mutaciones).

ESPÓSITO, Roberto. "Entrevista: Biopolítica y Filosofía” (entrevistado por Vanessa Lemm e Miguel Vatter). In.: Revista de Ciencia Política, vol. 29, nº 1, 2009, pp. 133 141, Pontificia Universidade Católica de Chile, Santiago, Chile. 
FABRE, Luis Felipe. "No hay palabras: "Hay Cadáveres"”. In.: Leyendo agujeros. Ensayos sobre (des)escritura, antiescritura y no escritura. México: Fondo Editorial Tierra $2005 . \quad$ Adentro, Disponível em: http://laboratoriopoetico.blogspot.com/2008/12/no-hay-palabras-hay-cadveres-luis.html. Acesso em julho de 2018.

FABBRI, Luis Carlos. "Os ensinamentos do Holocausto para atualidade e a busca da memória e da verdade do Brasil”. In. XXV Jornada Interdisciplinar sobre o Ensino da História do Holocausto em Defesa da Democracia e Cidadania. São Paulo, julho de 2013.

FERRER, Christian; BAIGORRIA, Osvaldo. "Prólogo: Perlongher prosaico". In: PERLONGHER, Néstor. Prosa plebeya: ensayos (1980-1992). Buenos Aires: Ediciones Colihue SRL, 1997.

FERRO, Gabriela Beatriz Mora. A poesia desterritorializante de Néstor Perlongher uma leitura de Hule (Dissertação de Mestrado). Departamento de Letras Modernas da Universidade de São Paulo, 2010. Disponível em: http://www.teses.usp.br/teses/disponiveis/8/8145/tde-23112010-140835/en.php. Acesso em 25 de julho de 2016.

FOUCAULT, Michel. História da sexualidade I: A vontade de saber. $13^{\mathrm{a}} \mathrm{ed}$. Trad. Maria Theresa da Costa Albuquerque e José Augusto Guilhon Albuquerque. Rio de Janeiro: Edições Graal, 1988. 
FOUCAULT, Michel. História da sexualidade II: o uso dos prazeres. $8^{\mathrm{a}}$ ed. Trad. Maria Theresa da Costa Albuquerque; revisão técnica José Augusto Guilhon Albuquerque. Rio de Janeiro: Edições Graal, 1984.

FRIEDRICH, Hugo. Estrutura da lírica moderna: da metade do século XIX a meados do século XX. Trad. do texto Marise M. Curioni. Trad. das poesias por Dora F. da Silva. São Paulo: Duas Cidades, 1978.

FRY, Peter. "Prefácio". In.: PERLONGHER, Néstor. O Negócio do Michê - a prostituição viril em São Paulo. São Paulo: Brasiliense, 1987.

GARCÍA HELDER, Daniel. "El neobarroco en la Argentina”. In.: Diario de Poesía, n’. 4, otoño de 1987, pp. 25-25.

GASPARINI, Pablo. "La lección de Néstor". In: Caracol: Revista do Programa de PósGraduação da Área de Língua Espanhola e Literaturas Espanhola e HispanoAmericana. Faculdade de Filosofia, Letras e Ciências Humanas. Universidade de São Paulo, n.1. (2010). São Paulo: FFLCH/ USP, 2010a.

GASPARINI, Pablo. "Néstor Perlongher: una extraterritorialidad en gozoso portuñol". In: Revista Iberoamericana. Vol. LXXVI, n. 232-233, dezembro de 2010b, pp. 757-775.

GASPARINI, Pablo: "No entremeio do trágico: Perlongher e os "Cadáveres" da nação". In: Estudos de Literatura Brasileira Contemporânea, n. 29. Brasília, jan. - jun. de 2007, pp. $165-178$.

GASPARINI, Pablo. "Las vueltas de Evita (reescrituras políticas en Walsh, Perlongher y Cucurto)". In. Revista Landa, vol. 5, $\mathrm{n}^{\mathrm{o}}$ 1, 2016. Disponível em: 
http://www.revistalanda.ufsc.br/Edicoes/v5ed1-2016.html\#. Acesso em 29 de dezembro de 2016.

GASPARRI, Javier. “Austria-Hungría de Néstor Perlongher: una violencia sexopolítica”. In. V Congresso Internacional de Letras, 2010, pp. 2320-2327. Disponível em: http://2010.cil.filo.uba.ar/sites/2010.cil.filo.uba.ar/files/343.Gasparri.pdf. Acesso em 26 de novembro de 2016.

GASPARRI, Javier. "Poesía y política en Néstor Perlongher”. In. Anclajes, v. XVI, nº 1, jul., 2012. Disponível em: $\quad$ http://www.scielo.org.ar/sci elo.php?script=sci_arttext\&pid=S1851-46692012000100002. Acesso em agosto de 2016.

GASPARRI, Javier. "El SIDA como espectáculo". In.: Boletín 17, del Centro de Estudios de Teoría y Crítica Literaria (Diciembre 2013). Disponível em: http://www.celarg.org/int/arch_publi/8f00b204e9-javier_gasparri17.pdf. Acesso em outubro de 2018.

GASPARRI, Javier. Néstor Perlongher. Por una política sexual Dissertação (Mestrado). Facultad de Humanidades y Artes, Universidad Nacional de Rosario, 2015. Disponivel em: http://plecrosario.org/nestor-perlongher-por-una-politica-sexual/. Acesso em agosto de 2018 .

GASPARRI, Javier. "Perlongher en la trinchera: sexualidade y afección". In.: VI Congresso Internacional de Estudos sobre a Diversidade Sexual e de Gênero da ABEH, 
https://www.academia.edu/34508485/PERLONGHER_EN_LA_TRINCHERA_SEXU

ALIDAD_Y_AFECCI\%C3\%93N. Acesso em agosto de 2018.

GINZBURG, Jaime. "O narrador na literatura brasileira contemporânea”. In.: Tintas. Quaderni di letterature iberiche e iberoamericane, 2 (2012), pp. 199-221. Disponível em: http://riviste.unimi.it/index.php/tintas. Acesso em janeiro de 2019.

GINZBURG, Jaime. Entrevista com Jaime Ginzburg: "Uma tendência na Literatura Brasileira: a narrativa de confinamento". In.: Fonteira Z - Revista do Programa de Estudos Pós-Graduados em Literatura e Crítica Literária, nº 13, 2014. Disponível em: http://revistas.pucsp.br. Acesso em janeiro de 2019.

GINZBURG, Jaime. Entrevista com Jaime Ginzburg: "Narração, confinamento e negatividade". In.: Fonteira Z - Revista do Programa de Estudos Pós-Graduados em Literatura e Crítica Literária, $\mathrm{n}^{\mathrm{o}}$ 13, 2014. Disponível em: http://revistas.pucsp.br. Acesso em janeiro de 2019.

GINZBURG, Jaime; HARDMANN, Francisco Foot (orgs.) Escritas da violência: o testemunho. Rio de Janeiro: 7Letras, 2012.

GIORGI, Gabriel. "Sueños de extermínio: Perlongher”. Disponível em: http://www.lehman.cuny.edu/ciberletras/v09/giorgig.html. Acesso em julho de 2016.

GONZÁLEZ, Horacio. “Introito: Perlongher y la crítica argentina”. In.: CANGI, Adrián; SIGANEVICH, Paula. Lúmpenes peregrinaciones: ensayos sobre Néstor Perlongher. Rosario: Beatriz Viterbo Editora, 1996. 
GREINER. Christine. O corpo: pistas para estudos indisciplinares. $2^{\mathrm{a}}$ ed. São Paulo: Annablume, 2005.

GREINER. Christine; AMORIM, Claudia (orgs.). Leituras da morte. São Paulo: Annablume, 2007.

GREINER. Christine. O corpo em crise: novas pistas e o curto-circuito das representações. São Paulo: Annablume, 2010.

GUATTARI, Félix; ROLNIK, Suely. Micropolítica. Cartografia do Desejo. Petrópolis: Editora Vozes, 1986.

GUILLÉN, Jorge. Lenguaje y poesía. Madrid: Alianza Editorial, 1972.

GUYER, Sara. "Buccality”. In: SCHWAB, Gabriele. Derrida, Deleuze, Psychoanalysis. New York: Columbia, 2008.

HAESBAERT, Rogério; BRUCE, Glauco. “A desterritorialização na obra de Deleuze e Guattari”. In.: GEOgraphia vol. 4, $\mathrm{n}^{\mathrm{o}} 7$ (2002). Disponível em: https://doi.org/10.22409/GEOgraphia2002.v4i7.a13419. Acesso em janeiro de 2019.

HOBSBAWM, Eric. Era dos extremos: o breve século XX: 1914-1991. Trad. Marcos Santarrita. São Paulo: Companhia das Letras, 1995.

IRIARTE, Ignacio. "La biblioteca de Néstor Perlongher”. In. La Habana Elegante Dossier "Cosa de locas: homenaje a Néstor Perlongher, n 53, primavera - verano, 2013. Disponível em: $\quad \underline{\text { http://www.habanaelegante.co }}$ /Spring_Summer_2013/March_2013.html. Acesso em jul. de 2016. 
JARDIM, Giovane Rodrigues; SOUZA, Cristiéle Santos de. "É possível a lírica após Auschwitz: uma propedêutica à dialética negativa de Adorno". In.: Revista Eletrônica Literatura e Autoritarismo - Dossiê $\mathrm{n}^{\circ}$ 12, Novembro de 2012. Disponível em: http://w3.ufsm.br/grpesqla/revista/dossie12/. Acesso em dezembro de 2017.

JIMENEZ, Reynaldo. “Templar”. In: PERLONGHER, Néstor. Poemas completos (1980-1992), edición y prólogo de Roberto Echavarren. Buenos Aires: Seix Barral, 1997.

KAMENSZAIN, Tamara. "El escudo de la muerte: de Lamborghini a Perlongher". Argentina/ Rio de La Plata: Culturas 7, 1988, pp. 115-120.

KAMENZAIN, Tamara. "Epílogo: El canto del cisne de Néstor Perlongher”. In. CANGI, Adrián; SIGANEVICH, Paula. Lúmpenes peregrinaciones: ensayos sobre Néstor Perlongher. Rosario: Beatriz Viterbo Editora, 1996.

KAMENSZAIN, Tamara. "Bordado y costura del texto". In.: Historias de amor (y otros ensayos sobre poesía). Buenos Aires: Paidós, 2000. pp. 207-211.

KAMENSZAIN, Tamara. "La que por un cisne”. In.: Boletim de Pesquisa do Núcleo de Estudos Literários \& Culturais (NELIC), v. 6, $\mathrm{n}^{\circ}$ 8/9 - Poesia: passagens e impasses, 2006. Disponível em: https://periodicos.ufsc.br/index.php/nelic/issue/view/249. Acesso em dezembro de 2018.

KLINGER, Diana Irene. Escrita de si, escritas do outro: autoficção e etnografia na narrativa latino-americana contemporânea. Tese (Doutorado) - Universidade Estadual do Rio de Janeiro (UERJ), 2006. Disponível em: 
http://www.dominiopublico.gov.br/pesquisa/DetalheObraForm.do?select_action=\&co_ obra=198038. Acesso em: junho de 2016.

KOVADLOFF, Santiago. O silêncio primordial: ensaios. Trad. de Eric Nepomuceno e Luís Carlos Cabral. Rio de Janeiro: José Olympio, 2003.

KRISTEVA, Julia. Pouvoirs de l'horreur: essai sur l'abjection. Paris: Les Éditions du Seuil, 1980.

LEMM, Vanessa; VATTER, Miguel. Entrevista: "Biopolítica y Filosofía". In.: Revista de Ciencia Política”, v. 29, no 1, Santiago do Chile, 2009, pp. 133-141. Disponível em: https://scielo.conicyt.cl/scielo.php?script=sci_arttext\&pid=S0718-90X2009000100007. Acesso em agosto de 2018.

LENOTTI, Christopher Larkosh. “'Aqueles dois”: As cartografias multilíngues de Néstor Perlongher e Caio Fernando Abreu". In: Estudios - Revista de Investigaciones Literarias y Culturales, $\mathrm{n}^{\circ} 24,2004$, pp. 177-195.

LEÓN, Gonzalo. “Una unidad plebeya” In.: Revista Bazar Americano, nov. - dic., 2013, XXI, no 44. Disponível em: https://editorialexcursiones.com/2013/11/13/una-unidadplebeya-por-gonzalo-leon-revista-bazaramericano-noviembre-2013/. Acesso em julho de 2018.

LIBRANDI-ROCHA, Marília. "Escutar a escrita: por uma teoria literária ameríndia". In: O eixo e a roda, v.21, n. 2, Belo Horizonte, 2012, pp.1709-202.

LINS, Vera. "A poesia em tempos de guerra: uma tentativa de ler a poesia brasileira contemporânea no contexto da violência”. In: SELIGMANN-SILVA, Márcio; 
GINZBURG, Jaime; HARDMANN, Francisco Foot (orgs.) Escritas da violência: o testemunho. Rio de Janeiro: 7Letras, 2012.

MAFFESOLI, Michel. El tiempo de las tribus. Barcelona: Icaria, 1990.

MAFFESOLI, Michel. De la orgía. Barcelona: Ariel, 1996.

MAFFESOLI, Michel. Sobre o nomadismo. Trad. Marcos de Castro. Rio de Janeiro: Record, 2001.

MAGRI, Milena Mulatti. “A AIDS nas crônicas de Caio Fernando Abreu”. In. Revista Estação Literária, Londrina, vol. 11, pp. 170-182, jul. 2013. Disponível em: www.uel.br/pos/letras/EL/vagao/EL11-Art12.pdf. Acesso em janeiro de 2019.

MANDOLESSI, Silvana. Una literatura abyecta: Gombrowicz en la tradición argentina. Amsterdam: Rodopi, 2012.

MARANHÃO, José Luis de Sousa. O que é morte. São Paulo: Editora Brasiliense, 2017.

MARCONI, Rodrigo. "Tradição e vanguarda na obra "Acrilírico" de Caetano Veloso e Rogério Duprat". In.: REVISTA BRASILEIRA DE MÚSICA - PROGRAMA DE PÓSGRADUAÇÃO EM MÚSICA (UFRJ), Rio de Janeiro, v. 25, n. 1, p.79-102, jan. - jun. 2012. Disponível em: $\quad$ http://www.rodrigomarconi.com/wpcontent/uploads/2016/01/rbm25-1-04.pdf. Acesso em novembro de 2018.

MARTINS, Fernanda Almeida Vittorino. O homem, a morte e o tempo. Trabalho de Conclusão de Curso (TCC em Psicologia). Universidade Estadual da Paraíba, Centro de Ciências Biológicas e da Saúde, Campina Grande/ Paraíba, 2013. 
MEJÍA, Rafael Estrada. "Micropolíticas, cartografias e heterotopias urbanas: derivas teórico-metodológicas sobre a aventura das (nas) cidades contemporâneas". In.: Revista Espaço Acadêmico - Dossiê Rastros urbanos: encontros, experiências e narrativas, $\mathrm{n}^{\circ}$ 132, ano XI, maio de 2012. Disponível em: https://www.periodicos.uem.br. Acesso em março de 2019.

MENDES, Conrado Moreira. “Algumas abordagens para o estudo da voz”. In.: ANAISSeminários Teóricos Interdisciplinares do SEMIOTEC - I STIS. Nov/2012. Disponível em: $\quad$ http://www.periodicos.letras.ufmg.br/index.php/stis/article/view/1855/2211. Acesso em: 16 de julho de 2018.

MIZRAHI, Rachel. "Direito à Memória". In. XXV Jornada Interdisciplinar sobre o Ensino da História do Holocausto em Defesa da Democracia e Cidadania. São Paulo, julho de 2013.

NANCY, Jean-Luc. À escuta. Trad. De Fernanda Bernardo. Belo Horizonte: Edições Chão da Feira, 2014.

NASCIMENTO, Evando (org.). Jacques Derrida: pensar a desconstrução. Trad. Evando Nascimento ... [et al]. São Paulo: Estação Liberdade, 2005.

OLMOS, Ana Cecilia. "Nota editorial”. In.: Cuadernos de recienvenido. Publicação do Programa de Pós-Graduação em Língua Espanhola e Literaturas Espanhola e HispanoAmericana, do Departamento de Letras Modernas, da Faculdade de Filosofia, Letras e Ciências Humanas, da Universidade de São Paulo, n. 19, São Paulo: Humanistas, 2004. 
PALMEIRO, Cecilia. "Locas, milicos y fusiles: Néstor Perlongher y la última dictadura argentina”. In: Estudios, jul. - dic., 2011, pp. 9-25.

PANESI, Jorge. “Cosa de locas: las lenguas de Néstor Perlongher”. In. La Habana Elegante - Dossier “Cosa de locas: homenaje a Néstor Perlongher, $\mathrm{n}^{\circ}$ 53, primavera verano, 2013. Disponível em: $\underline{\text { http://www.habanaelegante.co }}$ m/Spring_Summer_2013/March_2013.html. Acesso em jul. de 2016.

PAVIANI, Jayme. “Traços fislosóficos e literários nos textos”. In. ROHDEN, L; PIRES, C. (orgs.). Literatura e filosofia: uma relação transacional. Ijuí: Unijuí, 2009, pp. 61-77.

PAVIANI, Jayme. “O ensaio como gênero textual”. In.: Simpósio Internacional de Estudo de Gêneros Textuais: O ensino em foco, agosto, 2009, Caxias do Sul. Disponível em: $\quad$ https://www.escrevendoofuturo.org.br/arquivos/65/o-ensaio-como-generotextual.pdf. Acesso em julho de 2018.

PAZ, Octavio. O arco e a lira. Rio de Janeiro: Nova Fronteira, 1984.

PERLONGHER, Néstor. Austria-Hungría. In.: Poemas completos (1980-1992). Buenos Aires: Seix Barral, 1997a.

PERLONGHER, Néstor. "Disciplinar os poros e as paixões”. In.: Lua nova: Revista de cultura e política, vol. 2, $\mathrm{n}^{\text {o }}$ 3, São Paulo, dezembro de 1985. Disponível em: http://dx.doi.org/10.1590/S0102-64451985000400007. Acesso em novembro de 2018.

PERLONGHER, Néstor. Alambres. In.: Poemas completos (1980-1992). Buenos Aires: Seix Barral, 1997a. 
PERLONGHER, Néstor. O Negócio do Michê - a prostituição viril. São Paulo: Brasiliense, 1987a.

PERLONGHER, Néstor. O que é AIDS. São Paulo: Brasiliense, $1987 \mathrm{~b}$.

PERLONGHER, Néstor. El fantasma del SIDA. Buenos Aires: Ed. Puntosur, 1988.

PERLONGHER, Néstor. Hule. In.: Poemas completos (1980-1992). Buenos Aires: Seix Barral, 1997a.

PERLONGHER, Néstor. "Nueve meses en París". In.: Hispamérica, ano 28, n 84, diciembre 1999, pp. 53-57. Disponível em: https://www.jstor.org/stable/20540156?seq=1\#metadata_info_tab_contents. Acesso em agosto de 2018.

PERLONGHER, Néstor. Parque Lezama. In.: Poemas completos (1980-1992). Buenos Aires: Seix Barral, 1997a.

PERLONGHER, Néstor. Aguas aéreas. In.: Poemas completos (1980-1992). Buenos Aires: Seix Barral, 1997a.

PERLONGHER, Néstor. Caribe transplatino: Poesia neobarroca cubana e rioplatense. Trad. Josely Vianna Baptista. São Paulo: Iluminuras, 1991.

PERLONGHER, Néstor. El chorreo de las iluminaciones. In.: Poemas completos (19801992). Buenos Aires: Seix Barral, 1997a. 
PERLONGHER, Néstor. La prostitución masculina. Buenos Aires: Ediciones de la Urraca, 1993. Disponível em: https://pt.scribd.com/doc/16661912/Perlongher-NestorLa-Prostitucion-Masculina. Acesso em agosto de 2018.

PERLONGHER, Néstor. Lamê: Antologia bilíngue espanhol português. Trad. Josely Vianna Baptista. São Paulo: Editora da Universidade Estadual de Campinas (UNICAMP), 1994.

PERLONGHER, Néstor. “Territórios marginais”. In: MAGALHÃES, Maria Cristina Rios (Org.). Na sombra da cidade. São Paulo: Editora Escuta, 1995, pp. 81-116.

PERLONGHER, Néstor. Poemas completos (1980-1992). Buenos Aires: Seix Barral, 1997a.

PERLONGHER, Néstor. Prosa plebeya: ensayos (1980-1992). Argentina, Buenos Aires: Ediciones Colihue SRL, 1997b.

PERLONGHER, Néstor. “El portuñol en la poesía”. São Paulo, dez, 1984. Reproduzido em Tsé Tsé, no 7/8, Buenos Aires, mayo 2000, pp. 254-259.

PERLONGHER, Néstor. Evita vive e outras prosas. São Paulo: Iluminuras, 2001.

PERLONGHER, Néstor. Homenaje a Néstor Perlongher. In. Cuadernos de Recienvenido, $\mathrm{n}^{\circ}$ 18, 2002, São Paulo: Humanitas /FFLCH/ USP.

PERLONGHER, Néstor. Papeles insumisos. Buenos Aires: Santiago Arcos, 2004. 
PERLONGHER, Néstor. “'Cadáveres' de Néstor Perlongher, recitado por el autor”. Disponível em: https://www.youtube.com/watch?v=wJZKXwrOXb8 . Acesso em março de 2015 .

PERRONE, Charles. "Poesia Concreta e Tropicalismo". In.: Revista USP (4), 55-64. Disponível em: https://doi.org/10.11606/issn.2316-9036.v0i4p55-64. Acesso em novembro de 2018.

PIZARNIK, Alejandra. "Piedra Fundamental" (1971). In.: Obras completas - poesía completa y prosa selecta (1936-1972). Buenos Aires: Corregidor, 1994.

PORRÚA, Ana. “'Cosas que se están hablando': versiones sobre el neobarroco”. In.: Boletín 13/14, del Centro de Estudios de Teoría y Crítica Literaria (diciembre 2007, abril 2008). Disponível em: http://www.celarg.org/int/arch_publi/porrua13_14.pdf. Acesso em janeiro de 2018.

PORRÚA, Ana. Caligrafía tonal: ensayos sobre poesía. Buenos Aires: Editorial Entropía, 2011.

PORRÚA, Ana. "El lugar de los restos”. In. La Habana Elegante - Dossier "Cosa de locas: homenaje a Néstor Perlongher, $\mathrm{n}^{\circ}$ 53, primavera - verano, 2013. Disponível em: http://www.habanaelegante.com/Spring_Summer_2013/March_2013.html. Acesso em julho de 2016.

PRADO FILHO, Kleber; TETI, Marcela Montalvão. “A cartografia como método para as ciências humanas e sociais”. In.: Barbarói, n 38, Santa Cruz do Sul, junho de 2013. Disponível em: http://pepsic.bvsalud.org. Acesso em janeiro de 2019. 
PRECIADO, Paul B. "História da Tecnossexualidade". In.: PRECIADO, Paul B. Testo Junkie: sexo, drogas e biopolítica na era farmacopornográfica. São Paulo: N-1 edições, 2018. Disponível em: http://clinicand.com/2018/06/21/historia-da-tecnossexualidadepor-paul-preciado/. Acesso em maio de 2018.

PRIETO, Julio. “Cercanía del escarpe, o de la bajura en Perlongher”. In: La escritura errante: ilegibilidad y políticas del estilo en Latinoamérica. Madrid: IberoamericanaVervuert, 2016.

QUIROGA, José. "El chorro de Néstor". In. La Habana Elegante - Dossier "Cosa de locas: homenaje a Néstor Perlongher, $\mathrm{n}^{\circ}$ 53, primavera - verano, 2013. Disponível em: http://www.habanaelegante.com/Spring_Summer_2013/March_2013.html. Acesso em julho de 2016.

RANCIÈRE, Jacques. “O dissenso". In: A crise da razão. Organizador Adauto Novaes. São Paulo: Companhia das Letras; Brasília, DF: Ministério da Cultura; Rio de Janeiro: Fundação Nacional de Arte, 1996.

RANCIÈRE, Jacques. Políticas da escrita. Trad. De Raquel Ramalhete [et al]. Rio de Janeiro: Editora 34, 1995. (Coleção TRANS).

RIMBAUD, Arthur. Poesia completa: Arthur Rimbaud. Trad., prefácio e notas de Ivo Barroso. Rio de Janeiro: Topbooks, 1995.

ROSA, Nicolás. "Una ortofonía abyecta”. In. CANGI, Adrián; SIGANEVICH, Paula. Lúmpenes peregrinaciones: ensayos sobre Néstor Perlongher. Rosario: Beatriz Viterbo Editora, 1996. 
ROSA, Nicolás. Tratados sobre Néstor Perlongher. Buenos Aires: Editorial Ars, 1997.

ROSA, Nicolás. "De estos polvos, estos lodos...". In. Cuadernos de Recienvenido: Homenaje a Néstor Perlongher. São Paulo: Humanitas/ FFLCH/ USP, 2002, pp. 23-48.

SANTOS, Célia Regina dos; WIELEWICKI, Vera Helena Gomes. "Literaturas de autoria de minorias étnicas e sexuais". In: BONNICI, Thomas; ZOLIN, Lúcia (orgs.). Teoria literária: abordagens históricas e tendências contemporâneas. $3^{\mathrm{a}}$ ed. rev. e ampl. Maringá: EDUEM, 2009, pp. 337-352.

SANTOS, João Pedro. Um passeio com Tânatos: a ficcionalização da morte nos contos de Lygia Fagundes Telles. Dissertação (Mestrado em Letras). Pontifícia Universidade Católica do Rio Grande do Sul (PUC-RS). Porto Alegre, 2017. Disponível em: https://www.repositorio.pucrs.br. Acesso em janeiro de 2019.

SARAMAGO, José. O homem duplicado. São Paulo: Companhia das Letras, 2002.

SARDUY, Severo. Escrito sobre um corpo. São Paulo: Editora Perspectiva, 1979.

SIGANEVICH, Paula. "A propósito de Evita vive y otras prosas". In.: Cuadernos de Recienvenido/ 18 - Homenaje a Néstor Perlongher. São Paulo: Humanitas/ FFLCH USP, 2002, pp. 13-15. Disponível em: http://www.elortiba.org/old/pdf/recienvenido18.pdf. Acesso em julho de 2018.

SILVA, Eni Leide C. “AIDS e preconceito: uma abordagem psicosocial” (1991). Disponível: http://www3.crt.saude.sp.gov.br/arquivos/arquivos_biblioteca_crt/M44.pdf. Acesso em janeiro de 2019. 
SILVA, Fernando Manuel Machado Pinto da. Da Literatura, do Corpo e do Corpo na Literatura: Derrida, Deleuze e Monstros do Renascimento. Dissertação de Mestrado. Universidade de Évora, Évora, 2007.

SISCAR, Marcos. Poesia e crise: ensaios sobre a "crise da poesia" como topos da modernidade. Campinas: Editora da UNICAMP, 2010.

SOARES, Thiago. "O pixel da voz”. In.: Revista Fronteiras: estudos midiáticos, 16(1): 20-27, janeiro/abril 2014.Disponível em: http://webcache.googleusercontent.com/search?q=cache:DXt6i6tfTScJ:revistas.unisinos

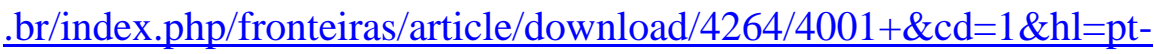

$\underline{B R \& c t=c l n k \& g l=b r}$. Acesso em: 16 de julho de 2018.

SOERENSEN, Claudiana. “A Carnavalização e o riso segundo Mikhail Bakhtin”. In.: Revista Travessias, vol. $5, \quad \mathrm{n}^{\mathrm{o}} 1$ (2011). Disponível em: http://saber.unioeste.br/index.php/travessias/article/view/4370/3889. Acesso em março de 2018.

SONTAG, Susan. "Notes on 'Camp", 1964. Disponível em: https://faculty.georgetown.edu/irvinem/theory/Sontag-NotesOnCamp-1964.html. Acesso em março de 2018.

SONTAG, Susan. Doença como metáfora, AIDS e suas metáforas. Trad. Paulo Henriques Britto e Rubens Figueiredo. São Paulo: Companhia das Letras, 2007. 
TORRES, Daniel. “Escritura de la perversión la de Néstor Perlongher”. Disponível em: http://www.cromrev.com/volumes/2001-VOL20/01-Torres-2001-vol20.pdf. Acesso em nov. de 2016.

TREVISAN, João Silvério. Devassos no paraíso: A homossexualidade no Brasil, da colônia à atualidade. $4^{\mathrm{a}}$ ed. Rio de Janeiro: Record, 2000.

VEIGA, Ana Maria. "Um território a ser definido: corpos, gênero e ditaduras". In: Revista de História Comparada, ano 3, vol.6, n.6. Rio de Janeiro: Universidade Federal do Rio de Janeiro, 2009.

VIVIAN, Ilse Maria da Rosa. "Barthes e a escritura: A leitura e proposição existencial". In.: Revista Língua \& Literatura, v. 17, n. 29, dez. 2015, pp. 23-34. Disponível em: http://revistas.fw.uri.br/index.php/revistalinguaeliteratura/article/view/2209/2082. Acesso em julho de 2018.

ZAIDENWERG, Ezequiel. "Néstor Perlongher y sus cadáveres: del neobarroso a la necropoética”. In. Cuadernos de literatura, v. XIX, nº 38, jul.- dic. 2015, pp. 432-449. Disponível em: http://revistas.javeriana.edu.co/index.php/cualit/article/view/12971. Acesso em maio de 2016.

ZAPATA, Miguel Angel. "Néstor Perlongher: La parodia diluyente". Disponível em: http://digitalcommons.providence.edu/cgi/viewcontent.cgi?article=1396\&context=inti. Acesso em julho de 2016.

ZARONE, Giusseppe. Metafísica de la ciudad. Encanto utópico y desencanto metropolitano. Valencia: Pretextos, 1993. 
ZUMTHOR, Paul. Performance, recepção, leitura. Tradução de Jerusa Pires Ferreira e Suely Fenerich. São Paulo: EDUC, 2000.

WEINBERG, Liliana. Situación del ensayo. México: Centro Coordinador y Difusor de Estudios Latinoamericanos - Universidad Nacional Autónoma de México, 2006. (Literatura y ensayo en América Latina y el Caribe, vol. I). 